\title{
WestVirginiaUniversity
}

THE RESEARCH REPOSITORY @ WVU

Graduate Theses, Dissertations, and Problem Reports

2000

\section{Dynamic property evaluation of frother}

\author{
Yunkai Xia \\ West Virginia University
}

Follow this and additional works at: https://researchrepository.wvu.edu/etd

\section{Recommended Citation}

Xia, Yunkai, "Dynamic property evaluation of frother" (2000). Graduate Theses, Dissertations, and Problem Reports. 1093.

https://researchrepository.wvu.edu/etd/1093

This Thesis is protected by copyright and/or related rights. It has been brought to you by the The Research Repository @ WVU with permission from the rights-holder(s). You are free to use this Thesis in any way that is permitted by the copyright and related rights legislation that applies to your use. For other uses you must obtain permission from the rights-holder(s) directly, unless additional rights are indicated by a Creative Commons license in the record and/ or on the work itself. This Thesis has been accepted for inclusion in WVU Graduate Theses, Dissertations, and Problem Reports collection by an authorized administrator of The Research Repository @ WVU. For more information, please contact researchrepository@mail.wvu.edu. 


\title{
Dynamic Property Evaluation of Frother
}

\author{
Yunkai Xia
}

Thesis submitted to the

College of Engineering and Mineral Resources

at West Virginia University

in partial fulfillment of the requirements

for the Degree of

\author{
Master of Science \\ in \\ Mineral Engineering
}

Felicia F. Peng, Ph.D. Chair

Eung Ha Cho, Ph. D.

David C. Yang, Ph. D.

Department of Mining Engineering

Morgantown, West Virginia

2000

Keywords: Frothers, Frothability, Initial Dynamic Froth Index, Bubble Coalescence Rate, Fine Coal Flotation 


\section{ABSTRACT \\ Dynamic Property Evaluation of Frother}

\section{Yunkai Xia}

Fourteen solvents were evaluated through frothing test and laboratory flotation batch tests. A new frothing parameter, initial dynamic froth index (IDFI), is proposed to compare the frothability of solvent. IDFI is derived from initial retention time of froth instead of retention time. IDFI is defined as the limiting slope of the initial retention time versus concentration curves while the concentration approaches zero. IDFI value depends on chemical structure and molecular weight of the solvent. Combined with normalized frothability index (NFI), normalized collapse rate constant $\left(\mathrm{NK}_{\mathrm{c}}\right)$, hydrophilic-lipophilic balance (HLB) and dynamic froth index (DFI), IDFI can be a useful index in evaluating the frothability of a solvent tested. Based on correlation between laboratory flotation of fine coals and IDFI values, the preliminary selection of a solvent as a potential flotation frother is made. 


\section{ACKNOWLEDGEMENTS}

The author would like to express his deep appreciation to his advisor and thesis committee Chair, Dr. Felicia F. Peng, for her persistent guidance and encouragement without which the present work could not have been possible. The valuable suggestions and comments by the thesis committee members, Dr. Eung Ha Cho and Dr. David, C. Yang, are greatly appreciated.

This research was sponsored by Union Carbide Corporation, South Charleston, West Virginia. The financial support from this project to the author in pursuing his $\mathrm{M}$. S. degree in Mining Engineering, CEMR, WVU is greatly acknowledged.

The author wishes to give thanks to his family members in China for their constant encouragement and moral support, and to his wife, Ren, Zimin and his son, Xia, Suyu for their constant love and understanding. 


\section{TABLE OF CONTENTS}

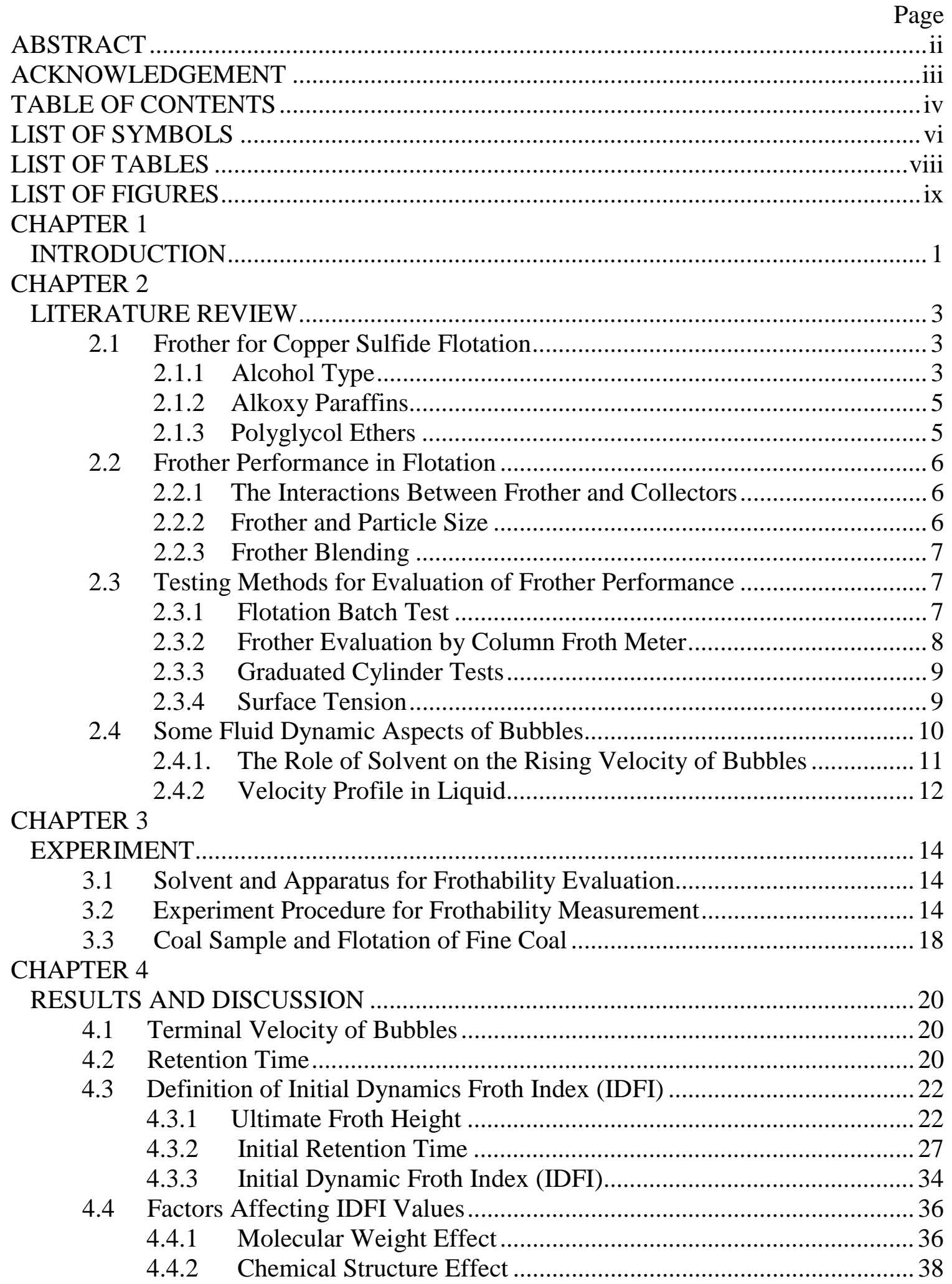


4.4.3 Hydrophilic-Lipophilic Balance (HLB) Effect ........................... 39

4.5 Coal Flotation and IDFI .................................................................. 43

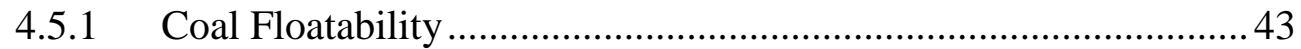

4.5.2 Coal Yield .................................................................... 43

4.5.3 Flotation Efficiency and Flotation Selectivity............................ 49

4.5.4 Particle Size Effect .............................................................. 49

4.6 Evaluation of Frothers Based on IDFI Values ........................................ 54

\section{CHAPTER 5}

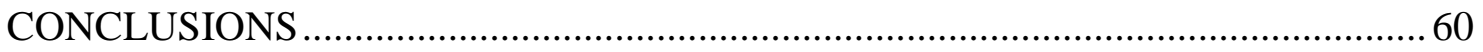

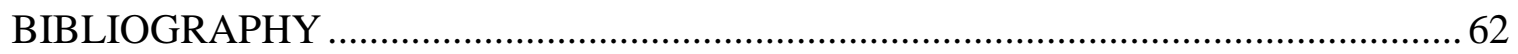

Appendix A Physical and Chemical properties of Solvents ..................................65

Appendix B Step Growth Model for Bubble Coalescence ....................................... 72

Appendix C Source Code for Determination of the parameters of

Flotation Rate Equation............................................................ 79

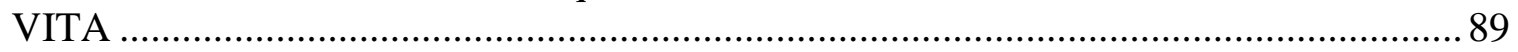




\section{LIST OF SYMBOLS}

\begin{tabular}{|c|c|}
\hline $\mathrm{A}_{\mathrm{c}}$ & clean coal ash content \\
\hline $\mathrm{A}_{\mathrm{f}}$ & ash content of flotation feed \\
\hline $\mathrm{A}_{\mathrm{t}}$ & ash content of tailings \\
\hline [B] & number of bubbles in column \\
\hline $\begin{array}{l}{[\mathrm{B}]_{\mathrm{o}}} \\
\mathrm{d}\end{array}$ & initial number of bubbles in column \\
\hline $\mathrm{C}$ & solvent concentration \\
\hline $\mathrm{C}_{\mathrm{d}}$ & drag coefficient \\
\hline DFI & dynamic frothability index \\
\hline $\mathrm{E}_{\mathrm{sp}}$ & separation efficiency \\
\hline $\mathrm{F}$ & froth volume of test frother \\
\hline $\mathrm{F}_{1}$ & froth volume of standard frother \\
\hline FI & frothability index \\
\hline $\mathrm{g}$ & gravity constant \\
\hline $\mathrm{H}$ & froth height \\
\hline $\mathrm{H}_{\mathrm{f}}$ & final total froth height \\
\hline $\mathrm{H}_{\mathrm{i}}$ & initial liquid height \\
\hline IDFI & initial dynamic frothability index \\
\hline IRT & initial retention time \\
\hline $\mathrm{K}_{\mathrm{c}}$ & bubble collapse rate constant \\
\hline $\mathrm{K}_{\mathrm{d}}$ & bubble volume constant \\
\hline $\mathrm{K}_{\mathrm{f}}$ & bubble frother concentration constant \\
\hline $\mathrm{K}$ & flotation rate constant \\
\hline NFI & normalized frothability index \\
\hline $\mathrm{NK}_{\mathrm{c}}$ & normalized bubble collapse rate constant \\
\hline $\mathrm{p}$ & mole volume of froth \\
\hline Q & aeration rate \\
\hline $\mathrm{r}$ & bubble radius \\
\hline $\mathrm{R}_{\mathrm{A}}$ & ash recovery in clean coal product \\
\hline $\mathrm{R}_{\mathrm{C}}$ & combustible recovery in clean coal product \\
\hline $\mathrm{R}_{\text {calc }}$ & calculated value of some components \\
\hline $\mathrm{Re}$ & Reynolds number \\
\hline $\mathrm{R}_{\mathrm{obs}}$ & observed value of some components \\
\hline
\end{tabular}




\section{LIST OF SYMBOLS}

(Cont'd)

$\begin{array}{ll}R m & \text { ultimate recovery } \\ R t & \text { retention time of froth } \\ \mathrm{Rt}_{\mathrm{a}} & \text { limiting retention time } \\ \mathrm{S} & \text { time of froth persistence of standard frother } \\ \mathrm{S}_{1} & \text { time of froth persistence of test frother } \\ \mathrm{SI} & \text { selectivity index } \\ \mathrm{t} & \text { time } \\ \mathrm{T} & \text { aeration rate } \\ \mathrm{U}_{\mathrm{g}} & \text { average retention time } \\ \mathrm{V}_{\mathrm{g}} & \text { average velocity of bubble rising } \\ \mathrm{V}_{\mathrm{t}} & \text { bubble terminal velocity in liquid } \\ \mathrm{Y}_{\mathrm{c}} & \text { yield of clean coal } \\ \mathrm{Y}_{\mathrm{f}} & \text { yield of tailings }\end{array}$

Greek Letters

$\rho_{\mathrm{L}} \quad$ water density

$\delta \quad$ surface tension 


\section{LIST OF TABLES}

Table

Page

2-1 Commercially available frother ---- their structure and commercial trade names..... 4

2-2 Value of Dynamic Frothability Index (DFI) ................................................. 9

2-3 Mole Volume Value $\mathrm{p}$ of some elements in frother......................................... 10

2-4 The calculated surface tensin of some commercial frother ................................... 10

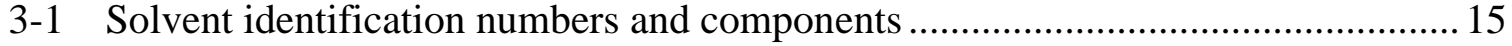

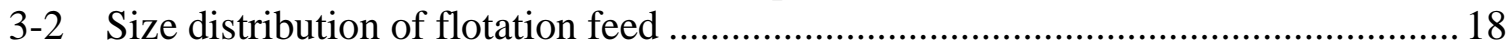

4-1 Ultimate froth height and volume constant as a function of frother concentration . 29

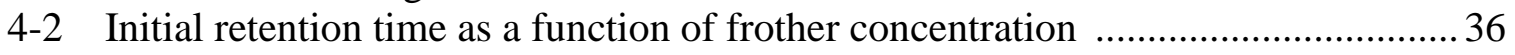

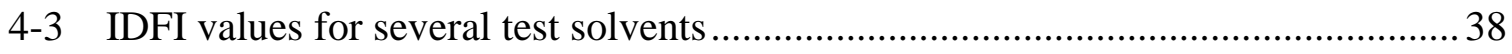

4-4 Hydrophilic-lipophilic balance (HLB) group numbers for solvent ....................... 39

4-5 Hydrophilic-lipophilic balance (HLB) for solvents ........................................... 39 


\section{LIST OF FIGURES}

Figure

Page

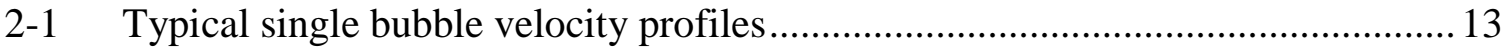

3-1 Schematic diagram of froth column meter....................................................... 16

3-2 Froth and initial interface in froth column meter............................................... 17

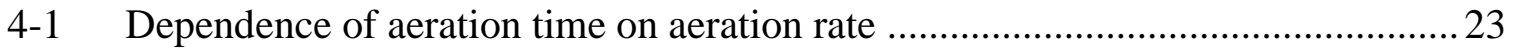

4-2 Froth height as a function of aeration rate in pure water ..................................2 24

4-3 Froth height as a function of aeration rate at various solvent concentration (MIBC, Solvent 2) .................................................................. 25

4-4 Froth height as afunction of aeration rate at varius solvent concentration (Butoxytriglycol, Solvent 3) .....................................................26

4-5 Froth height as a function of aeration rate for selected solvent

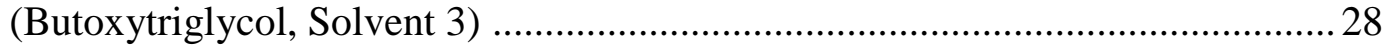

4-6a Initial retention time as a function of solvent concentration................................. 31

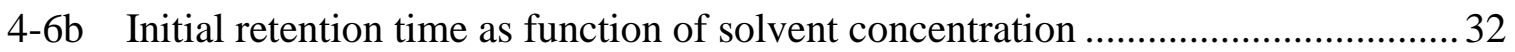

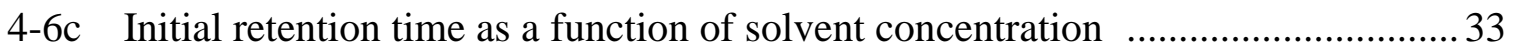

4-7 Iinitial retention time as a function of solvent concentration

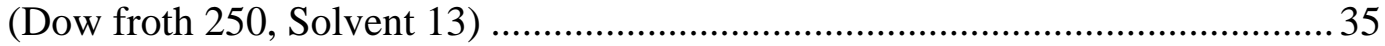

4-8 Dependence of IDFI value on molecular weight .............................................. 37

4-9 Correlation between hydrophilic-lipophilic balance (HLB) and molecular weight ................................................................................ 41

4-10 Correlation between initial dynamic froth ability index IDFI and hydrophilic-lipophilic balance (HLB) values ................................................. 42

4-11 Ultimate combustible recovery and rate constant as a function of IDFI*C......... 44

4-12a Ultimate combustible recovery and rate constant as a function of IDFI*C

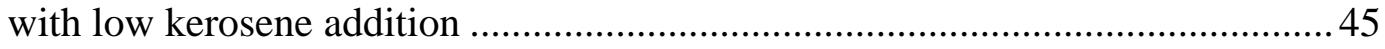

4-12b Ultimate combustible recovery and rate constant as a function of IDFI*C with high kerosene addition

4-13a Clean coal yield as a function of $\mathrm{IDFI}^{*} \mathrm{C}$ with low kerosene addition

4-13b Clean coal yield as a function of IDFI*C with high kerosene addition

4-14a Selectivity Index and Efficiency Index as a function of IDFI*C with low kerosene addition

4-14b Selectivity Index and Efficiency Index as a function of IDFI*C with high kerosene addition

4-15 Combustible recovery as a function of IDFI*C for different particle size fraction with low kerosene addition

4-16 Combustible recovery as a function of IDFI*C for different particle size fraction with high kerosene addition

4-17 Normalized frothability index (NFI) and normalized apparent bubble coalescence rate $\left(\mathrm{NK}_{\mathrm{C}}\right)$ relative to MIBC as a function of IDFI 


\section{LIST OF FIGURES}

(Cont'd)

Figure

4-18 Relationship of combustible recovery, clean coal and normalized frothability index (NFI) relative to MIBC at different flotation time ......................................56

4-19 Relationship of clean coal ash\% and normalized apparent coalescence rate constant $\left(\mathrm{NK}_{\mathrm{C}}\right)$ relative to $\mathrm{MIBC}$

4-20 Flotation performance of fine coal using various solvents .................................58 


\section{CHAPTER 1}

\section{INTRODUCTION}

In mineral flotation process, when particle surface has been rendered hydrophobic by the use of a collector, the stability of bubble attachment, especially at the pulp surface, depends on the physical property of a frother. Frothers, therefore, play an important role in enhancing flotation efficiency.

Conventionally, a batch flotation test is used to make a comparative analysis of frother performance. Results are compared in terms of valuable mineral recovery and flotation rate (Hansen and Klimpel, 1985; Smar et al., 1994). This methodology is quite rapid and convenient, but due to the complexities in plant flotation, it is extremely difficult to make a reliable scale-up and predict behavior of a particular chemical as a valuable frother based only on tests in the laboratory batch flotation (Langhlln, 1993). Additionally, the interactions between frothers and collectors, water quality, collector dosage, frother dosage, system structure and the effect of particle size on the frothers, etc. may also affect the frothability of frothers.

Some investigators have developed several simple froth measurement methods to determine the froth volume for a given frother solution. Several frothing parameters and criteria have been proposed to evaluate frothers. The acceptable frothing parameters include froth volume and the time of persistence (Sun, 1953), frother retention time and the limiting slope of retention time as a function of frother concentration (Malysa, 1987). The criteria proposed by Sun include frothability index (FI), defined as the ratio of the froth volume of a test frother to the froth volume of a standard frother, and stability index (SI), defined as the ratio of the time of froth persistence of a test frother to the time of froth persistence of a standard frother. Although FI can evaluate froth volume directly, it is not related to any physical-chemical property of the system being investigated, and therefore might lead to an incorrect conclusion. The frothing parameter such as retention time, Rt, measures an average lifetime of the bubble in a given system. The value of Rt characterizes the solution itself, but it is not capable of characterizing the frother itself. Thus, a frothing parameter, which is a limiting slope of Rt (when the frother concentration approaches zero) and is named as the dynamic frothability index (DFI), was proposed by Malysa. Furthermore, the product of DFI and frother concentration provides the information as to the frothing properties of the frother under dynamic steady state conditions.

DFI requires a constant value of Rt for a given frother concentration, which is specifically defined as the ratio of froth volume to gas flow rate. In this study, various types of solvents are included for frothability determination, and it has been observed that not all the frothing agents studied exhibited the linear relationship between the froth volume and gas flow rate. Thus, it is inappropriate to apply DFI directly to the systems such as polyglycol ether type frothers, which consistently show the non-linear relationship between froth volume and gas flow rate. 
The purpose of this study is to evaluate the frothing characteristics of fourteen solvents for frothability determination. The specific objectives of this work include: (1) Setting up an apparatus to measure the froth volume and collapse rate; (2) Derivation the new frothing parameters and criteria for frothability evaluation; (3) Studying the flotation performance of fine coal by using various solvents; (4) Validating the frothability of the solvents by comparing the frothing parameters to the separation results of fine coal flotation; (5) Providing the frothing characteristics of the solvents for the formation of the stable "blended" or "balanced" frothers. 


\section{CHAPTER 2}

\section{LITERATURE REVIEW}

\subsection{Frothers for Copper Sulfide Flotation}

There are three main types of frothers. They are alcohols, alkoxyparaffins, and the polyglycol ethers. The commonly available commercial frothers are given in Table 2-1, which shows their structures, chemical and trade names (Crozier and Ottley, 1978; Crozier and Klimpel, 1985; Hansen and Klimpel, 1989, Laskowski, 1993). Commonly used industrial frothers are usually short chain or branched alcohols, and polypropylene glycol methyl ethers (poly PGME).

\subsubsection{Alcohol Type Aliphatic Alcohol}

Typical aliphatic alcohols used commercially are Methyl Isobutyl Carbinol (MIBC) and 2-ethyl hexanol. Aliphatic alcohols produce fine-textured and selective froths that are relatively brittle and thus not very persistent (Crozier and Ottley, 1978). A series of different mixtures of $\mathrm{C}_{6}$ to $\mathrm{C}_{8}$ alcohol have been marketed by a number of companies including CYTEC (former Cyanamid) and Oreprep as tailored frothers for different types of ores.

The alcohol based frother mixtures include mixed $\mathrm{C}_{6}$ to $\mathrm{C}_{9}$ alcohols, which are more selective than MIBC. The mixture of $\mathrm{C}_{4}$ to $\mathrm{C}_{7}$ alcohols plus hydrocarbon oil are used mainly for flotation of copper-molybdenite ores. They are also recommended for other minerals including talc, graphite, sulfur and coal. Mixed $\mathrm{C}_{4}$ to $\mathrm{C}_{7}$ alcohols produces a stronger froth than MIBC, but are less persistent than polypropylene glycols, pine oils and cresylic acids. Higher alcohols can produce stronger froths but are less persistent than polypropylene glycols. They are widely used in coal flotation (Crozier and Ottley, 1978).

\section{Cyclic Alcohol}

In the 1950s, eucalyptus oil was a popular frother used in Australia, and later pine oil became the dominant natural oil frother because of its greater availability. Increasing the amount of pine oil fed to the cell tends to flatten the froth, decrease froth volume, and cause surface spatter (Crozier and Klimpel, 1985). Typical analysis of pine oil includes Alpha terpineol 60-70 \%, Tertiary alcohols $10 \%$, Bornneol and frenchyl alcohol 10-15 $\%$, and Camphor 10-15\%. Pine oil can produce close knit froth, which favors recovery, but lowers concentrate grade. The natural oils, such as pine oil, all have collector's properties, variable consistency and uncertain availability. The natural cyclic alcohols, while historically popular, especially in copper flotation, is diminishing due to the 
Table 2-1 Commonly available frothers----their structures and commercial trade names

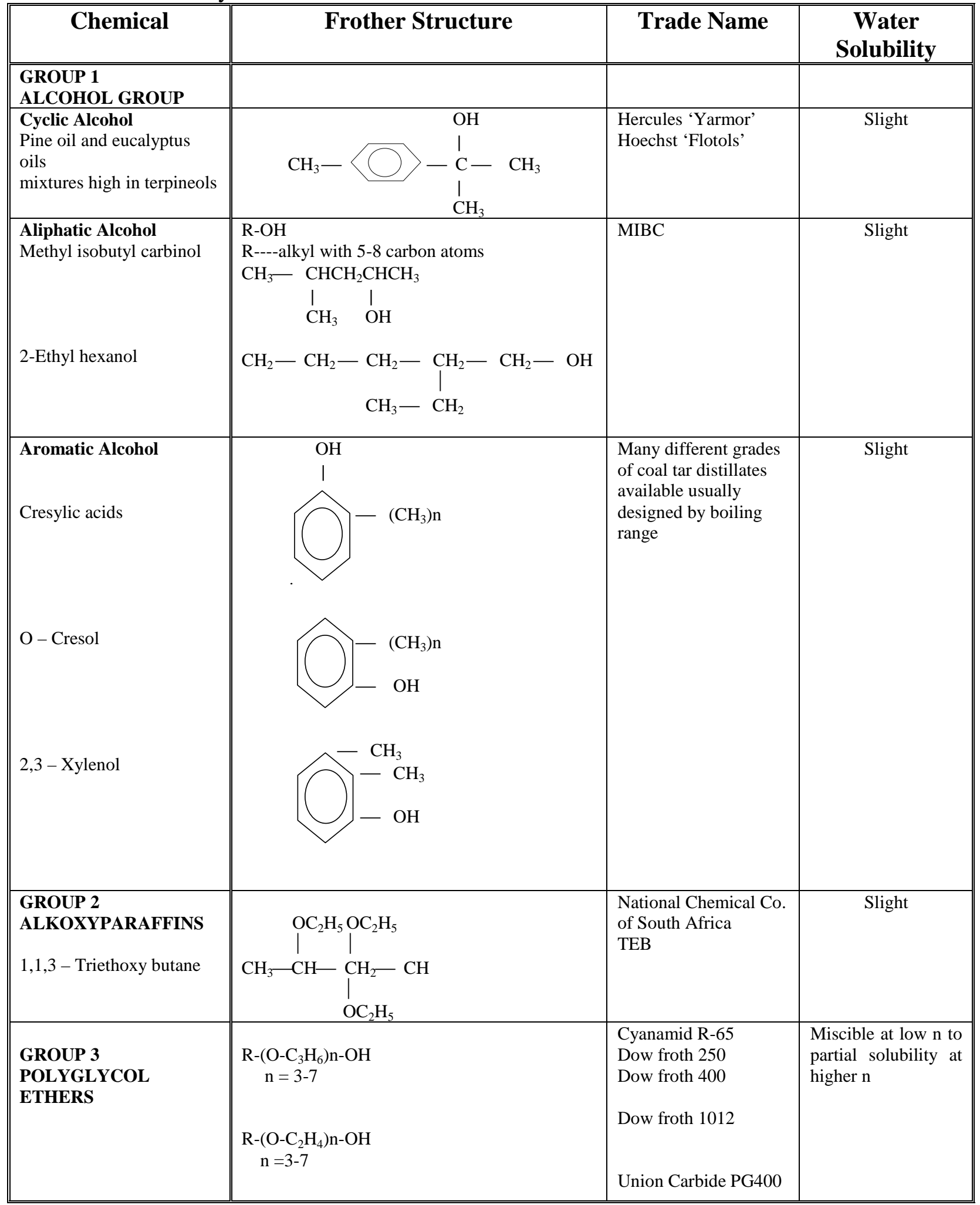


problems stated above. Currently, the mill operators are turning to MIBC and other synthetic non-collecting soluble frothers.

\section{Aromatic Alcohols}

Typical specifications for flotation grade cresylic acids are: distillation range of 190$235^{\circ} \mathrm{C}$, with less than $2 \%$ distilling below $190^{\circ} \mathrm{C}$, no less than $75 \%$ distilling below $235^{\circ} \mathrm{C}$, a density of 1.01 to $1.04 \mathrm{mg} / \mathrm{L}$ and a solubility of $1.7 \mathrm{~g} / \mathrm{L}$ in water. Typical commercial frothers are cut for boils between $220-250^{\circ} \mathrm{C}$ (Crozier and Ottley, 1978), and have typical compositions of meta, para-cresols, $0-1 \%$; 2, 4- and 2, 5-xylenols, 0-3\%; , 3- and 3, 5-xylenols, 10-12\%; 3, 4-xylenols, 20-30\%; and $\mathrm{C}_{9}$ phenols, 50-60\%. The same specification problems apply to the cresylic acids. As for pine oils, these products are also distilled from impure starting materials such as coal tars. Additionally, they have relatively strong collecting properties.

\subsubsection{Alkoxy Paraffins}

One of the best known products of alkoxy paraffins is TEB (triethoxybutane). However, this group of frothers has never had extensive applications outside South Africa.

\subsubsection{Polyglycol Ethers \\ Dow Froth Frothers}

The polypropylene glycol type of frothers represents the most flexible group of the synthetic frothers and is the second major class of commercial materials in use today. These are medium viscosity liquids that are uniform in quality and exhibit a wide spectrum of performance characteristics depending on molecular weight (commonly from 200 to $400 \mathrm{~g} / \mathrm{mol}$ ). The polypropylene glycol ether produces compact, lasting froth structures that break down readily in the cell. Unlike slightly soluble frothers, these frothers produce more tightly knit, more selective froths, and do not spatter on overfeeding the reagent. In addition, they range from being completely water-soluble with lower molecular weights to partially soluble with larger molecular weight. In general, they form fine froths that are somewhat selective and exhibit no collector action. These frothers are produced as byproducts of synthetic brake fluids. They are marketed by Dow Chemical Company (Midland, MI) under the name Dowfroth, by CYTEC (former Cynamid) as Aerofroth and ICI as Teefroth.

Most of the Dowfroth forthers are methoxy polypropylene glycols, with the general formula:

$$
\mathrm{CH}_{3}-\left[\mathrm{O}-\mathrm{C}_{3} \mathrm{H}_{6}\right]_{\mathrm{n}}-\mathrm{OH}
$$

Dowfroth 200, 250 and 1012 have molecular weights of 200, 250 and 400 respectively. Dowfroth 400 is a diol of 400 molecular weight of the formula:

$$
\mathrm{HO}-\left[\mathrm{C}_{3} \mathrm{H}_{6}\right]_{\mathrm{n}}-\mathrm{OH}
$$




\section{Union Carbide Frothers}

Union Carbide (South Charleston, WV) supplies similar products based on polypropylene glycols and polyethylene glycols, under the trade names PPG and Ucon, but there are little published papers regarding their characteristic properties in sulfide ore or coal flotation.

\subsection{Frother Performance in Flotation}

The flotation process may be considered as an interactive system consisting of many physico-chemical operation and equipment variables. Changing one of these variables may change the overall system response. The main factors that affect the frothability of frother include chemical structure of frother, interaction between collector and frother, collector dosage, frother dosage, dispersion of frothers, water quality, flotation system equipment structure and surface properties of particles.

\subsubsection{The Interactions Between Frothers and Collectors}

Ideally, the frother should not influence the state of mineral surface, however, the interaction does happen among the frother, collector, and solid surface (Laskowski, 1993). Many investigators have studied the interactions between frothers and collectors, and they concluded that the collector and the frother probably do not perform totally in independent functions, which complicates the selections of collectors and frothers (Crozier and Ottley, 1978). Leja et al. (1989) postulated that the occurrence of chemical interactions between collectors and frothers on the basis of froth suppression takes place under some sets of conditions. For example, certain proportions of sodium oleate and sodium alkyl sulphonate produce no froth, although each can give good froth with a small proportion of the other component. Sodium oleate and pine oil are incompatible when used in certain ratios. Similarly, in flotation of sphalerite, ethyl xanthate and cresol can suppress frothing completely when some quantity of cresol is added. Leja and Schulman (1954) postulated the simplest form of frother collector complex using interpenetration theory. They proposed that, in consequence of this tendency to interact, the actual attachment of collector-frother coated particles to frother-collector coated air bubble under dynamic conditions in flotation is analogous to penetration of the two interfaces, air/water and solid/water, leading to the establishment of a new solid/air interface.

\subsubsection{Frother and Particle Size}

The existing chemical products were originally designed and developed to adequately float average particles well. But when significant amounts of finer or coarser particles are present, their performance drops off (Klimpel, 1988). There is a significant difference in different frother chemical structures that actually float coarse particles (Klimpel and Hansen, 1987a; Klimpel and Hansen, 1987b). The polyglycol type frothers are more efficient in improving coarse particle recovery, while alcohol type frothers can be more effective in selective flotation of fine particles. No single chemical structure can effectively float a broad size range of particles. Individual chemical frother species have rather well defined optimal particle sizes and rate of flotation (Klimpel and Isherwood, 1991; Riggs, 1986). Thus, blending of frother chemicals for broad feed size distributions 
has gained more consideration (Klimpel, Hansen and Meyer, 1982; Klimpel and Hansen, 1987a).

\subsubsection{Frother Blending}

Aliphatic alcohols, such as MIBC, produces fine textured selective froth. The alkoxy type frothers, e.g. 1,1,3-triethoxybutane (TEB), are basically frother refinements of the previous alcohol types with similar overall characteristics. Dow froth frother families were found to be consistently capable of floating the larger particle than corresponding alcohol type frothers, which, however, were more selective for finer particle sizes.

Frother blending can not only make frother components to specifically match the existing flotation feed and then improve recovery of coarse particles, but also make it possible to improve flotation performance over single frother component. Klimpel (1995) studied the shifts in $\mathrm{Cu}$ recovery for various sizes as a function of collector dosage and changes in frother structure. The standard frother being used was polypropylene glycol methyl ether of a narrow molecular weight range centered on 250. For comparison, a frother, which consisted of a blend of polypropylene glycol methyl ethers ranging from 200 to 400 molecular weight at the intermediate collector dosage of $50 \mathrm{~g} / \mathrm{Mt}$, was used. The effect of the blended frothers on total recovery was noticeably greater than any change possible by changing the collector dosage. Being able to effectively recover mineral values in broader feed sizes by appropriate frother choice is quite easier and cheaper than doing the same by collector dosage manipulation. Klimpel (1988) observed that Dow froth 250 shows high recovery and low selectivity over both fine and coarse size fraction and XK 35004.00L gives both high recovery and good selectivity of the fine particles but somewhat lowers recovery of the coarse fraction. However, the blending of the Dow froth 1012 with XK 35004.00L frother gives good overall recovery and selectivity of both fine and coarse particles.

\section{3. Testing Methods for Evaluation of Frother Performance}

The commonly used methods for evaluation of frother performance are flotation, froth column meter and graduated cylinder tests.

\subsubsection{Flotation Batch Test}

Flotation batch test appears to be a common practice to make a comparative analysis of frother performance in flotation processes. This methodology, though quite easy and rapid, ignores the fact that the performance and behavior of a frother has been found to be affected by the nature of the associated collector. Nevertheless, results of batch flotation tests have been used as a basis to classify different frothers with respect to their quality. Hansen and Klimpel (1985) used a standardized batch laboratory technique involving an automated froth paddle removal system to collect reproducible time-recovery data as a function of particle size. The result is then characterized using a mathematical model of the form (Huber-Panu, et al., 1976).

$$
\mathrm{R}=\mathrm{R}_{\mathrm{m}}\left[1-\left(\frac{1}{\mathrm{Kt}}(1-\exp (-\mathrm{Kt}))\right)\right]
$$


where $\mathrm{R}$ is cumulative recovery of some component at time $t, \mathrm{R}_{\mathrm{m}}$ is the ultimate recovery of this component at infinite flotation time $(\mathrm{t} \rightarrow \infty)$, and $\mathrm{K}$ is a rate constant.

Dho et al. (1990) investigated the effects of flow rate and the nature of the floated mineral on the froth volume. These investigators also used the Equation (2-1) for analysis of their results to evaluate the frother performance in flotation. This mathematical model has been found to be an excellent simple model to represent coal/mineral flotation in the laboratory and in the plant.

\section{3. 2 Frother Evaluation by Column Froth Meter}

Since frothability and gas dispersion depend on surface activity of the frother at the gas-liquid interface, Dey et al. (1998) proposed that the evaluation of the frothers should be based on the comparison of a surface parameter which is directly related to the dynamic properties of gas/liquid interface. Sun (1952) used a column froth meter to measure the frothability of different alcohol frothers. The volume and persistence of froth were measured, respectively, at the end of 4 and 6 minutes of aeration at a constant rate of airflow. Two indexes were proposed in evaluating the test results. They are Frothability Index (FI) and Stability Index (SI):

$$
\begin{aligned}
& \mathrm{FI}=100\left(\mathrm{~F}_{1} / \mathrm{F}\right) \\
& \mathrm{SI}=100\left(\mathrm{~S}_{1} / \mathrm{S}\right)
\end{aligned}
$$

where $\mathrm{F}$ was froth volume of standard frother, $\mathrm{mL} / \mathrm{cm}^{2}$, and $\mathrm{S}$ was the time of froth persistence for the standard frother, s. $F_{1}$ and $S_{1}$ are the volume and the time of froth persistence for a new test frother, respectively. FI was a useful index to compare different frothers. However, the drawback of FI was that it is not related to any dynamic physico-chemical properties of the system being investigated. Therefore, it might lead to a wrong conclusion. For example, some frothers might exhibit the best frothability at some concentration, although less at arbitrary concentration. Laughlin et al. (1993) compared the frothers by using a froth column meter. Frother was aerated in a synthetic chalcocite $\left(\mathrm{Cu}_{2} \mathrm{~S}\right)$ slurry with a constant flow rate of air passed through a sintered glass disk at the base of the froth column. The froth height was used as a measure of frothing power, and the rate of froth collapse after termination of aeration was measured as a criterion for froth stability.

Malysa, et al. (1987) proposed to define a new parameter, dynamic frothability index (DFI), based on the parameter, Rt. Retention time, Rt, which was equal to the ratio of the froth volume, $\mathrm{Vg}$, to gas flow rate of aeration, $\mathrm{Ug}$, was used to evaluate frother. Rt values characterized the solution for a given concentration only, rather than the frother itself. These investigators proposed to define DFI as the limiting slope of the Rt versus concentration curve for $\mathrm{C} \rightarrow 0$.

$$
\mathrm{Rt}-2.4=\mathrm{Rt}_{\mathrm{a}}[1-\exp (-\mathrm{KC})]
$$

DFI was thus expressed as

$$
\mathrm{DFI}=\left.\frac{\mathrm{d}(\mathrm{Rt})}{\mathrm{dC}}\right|_{\mathrm{C} \rightarrow 0}=\mathrm{Rt}_{\mathrm{a}} \mathrm{K}
$$

when $\mathrm{C} \rightarrow 0$, Equation (2-4) is rewritten as

$$
\mathrm{Rt}-2.4=\mathrm{Rt}_{\mathrm{a}} \cdot \mathrm{K} \cdot \mathrm{C}=\mathrm{DFI} \cdot \mathrm{C}
$$


where $\mathrm{Rt}_{\mathrm{a}}$ is the limiting $\mathrm{Rt}$ values for $\mathrm{C} \rightarrow 0, \mathrm{~K}$ is a constant. DFI values can be determined on the basis of a set of experimental data. The value of 2.4 in Equations (2-4) and (2-6) is the value of Rt obtained for the distilled water used in experiments. The product of DFI and frother concentration, C, shown in Equation (2-6) provides the information of the frothing properties of a given frother. DFI is only applicable to the systems such as alcohol frothers, which produces the linear changing rate of the retention time with frother concentration. Some of the values obtained for the alcohols are given in Table 2-2.

Table 2-2 Value of Dynamic Frothability Index (DFI)

\begin{tabular}{|c|c|c|}
\hline \multirow[b]{2}{*}{ Alcohols } & \multicolumn{2}{|c|}{ DFI } \\
\hline & s.dm $/$ mole & $\mathrm{s} . \mathrm{dm}^{3} / \mathrm{g}$ \\
\hline Ethyl alcohol & $5.6 \times 10^{1}$ & 1.2 \\
\hline n-propyl alcohol & $2.8 \times 10^{2}$ & 4.7 \\
\hline n-butyl alcohol & $1.6 \times 10^{3}$ & 21.6 \\
\hline n-amyl alcohol & $4.6 \times 10^{4}$ & 52.3 \\
\hline n-Hexyl alcohol & $1.7 \times 10^{4}$ & 166.7 \\
\hline Diacetone alcohol & $2.9 \times 10^{3}$ & 25.0 \\
\hline$\alpha$-terpineol & $1.1 \times 10^{3}$ & 713.3 \\
\hline
\end{tabular}

\section{3. 3 Graduated Cylinder Tests}

This method was used by Numata (1991) to measure the amount of mineral particles sample was placed in a $100 \mathrm{~mL}$ frother solution. The graduated cylinder holding this mixed solution was placed in a thermostatically controlled water bath $\left(25^{\circ} \mathrm{C}\right)$ for 20 minutes. Air bubble was introduced by a $10 \mathrm{~mm}$ ID glass tube, which was pressed against the mineral particles for a few seconds. The particles picked up by the air bubbles were dried and weighted. The same experiment was repeated for ten times. The recorded result was the average weight of mineral particles for ten pick-up trials.

Dho et al. (1990) used the graduated cylinder method to clarify the dispersing mechanism of sodium silicate and froth characteristics in the anionic flotation of phosphate. The froth height and froth persistence was measured after the sample in a 100 $\mathrm{mL}$ glass-stopped graduated cylinder was vigorously shaken manually for $10 \mathrm{sec}$. The froth height was measured in terms of the milliliter divisions in each cylinder and then converted to centimeters. The froth persistence was determined in seconds until a frothfree area appeared at the surface.

\subsection{Surface tension}

Numuta (1991) showed that frothers could lower the surface tensions at a static equilibrium state. It was found that the surface tension lowering ability was largest for 4

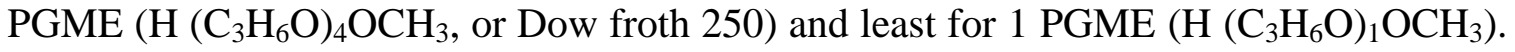
The surface tension lowering ability was closely related to the number of propylene groups in the molecule of poly PGME, which was highly soluble in water. In terms of the chemical structure, -O-, and -OH groups of poly PGME function both as proton 
donors as well as acceptors. The investigator applied Wang's equation (1982) to predict the frothability of different frothers, based on the computation of molecule structure.

$$
\sigma=\left[\left(\sum \mathrm{n} \times \mathrm{p}\right) \times \frac{\mathrm{d}}{\mathrm{M}}\right]^{4}
$$

where $\sigma\left(10^{-3} \mathrm{~N} / \mathrm{M}\right)$ is surface tension, $\mathrm{n}$ is number of the atoms of a given element in frother (see Table 2-3), $\mathrm{p}$ is the molar volume of the frother when the surface tension of the frother is $1(\mathrm{~N} / \mathrm{M}), \mathrm{M}$ is molecular weight, and $\mathrm{d}$ is density of the frother.

Table 2-3 Mole volume value $\mathrm{p}$ of some element in a frother

\begin{tabular}{|c|c|c|c|c|c|c||}
\hline Element & $\mathrm{H}$ & $\mathrm{C}$ & $\mathrm{O}$ & $\mathrm{N}$ & $\mathrm{S}$ & $\mathrm{Cl}$ \\
\hline \hline $\mathrm{P}$ & 17.1 & 4.8 & 20.0 & 12.5 & 48.2 & 54.3 \\
\hline
\end{tabular}

Table 2-4 shows that there is not much difference in the surface tensions among the different types of frothers studied. In practice, the investigator reported that there was marked difference in frothability for these frothers. In one case, MIBC even gave the

Table 2-4 Calculated surface tension of some commonly used frothers

\begin{tabular}{||l||c|c|c||}
\hline Frother & density $\left(\mathrm{g} / \mathrm{cm}^{3}\right)$ & Molecular weight & $\sigma\left(10^{-3} \mathrm{~N} / \mathrm{M}\right)$ \\
\hline \hline MIBC & 0.808 & 102.18 & 26.91 \\
\hline Hexyl Carbitol & 0.989 & 206.3 & 30.40 \\
\hline Ethoxytriglycol & 1.023 & 178.2 & 35.84 \\
\hline Butoxytriglycol & 0.935 & 190.3 & 32.03 \\
\hline 4 PGME (Dow froth 250) & 0.97 & 264 & 30.08 \\
\hline 1 PGME & $\sim 0.97$ & 90 & 37.89 \\
\hline
\end{tabular}

higher froth height than Dow froth 250. The shortcoming of the equation given by Wang was that the expression did not consider the position of the polar groups in the molecular structure.

Using the surface tension alone is not sufficient to estimate and compare the frothability of different frothers due to the highly dynamic nature and turbulence in flotation processes. From a practical viewpoint, for determining the potential of frothing agent for flotation, a preliminary screening of chemicals should be conducted using the general guidelines, and then followed by appropriate laboratory and plant flotation tests. Additionally, the interactions between collectors and frothers and other parameters in the flotation process system, etc. must be investigated before one can predict frothability of frothers.

\subsection{Some Fluid Dynamical Aspects of Bubbles}

The knowledge of the overall movement of gas bubble rising through a liquid or slurry is of great importance to understand frothing characteristics of frothing reagent in flotation process. 


\subsubsection{The Role of Frothing Reagent on the Rising Velocity of Bubbles}

A bubble rising in a liquid is subject to buoyancy force, gravity force and frictional (drag) force. The force balance on the bubble determines velocity. As a bubble rises in an aqueous surfactant solution, the surfactant accumulates on the bubble surfaces. The adsorbed surfactant molecule is oriented in such a way that the polar group is directed towards the solution, while the hydrocarbon chain points towards the gas phase. If the velocity of a bubble is high enough, the distribution of the adsorbed species will deviate from the equilibrium state. The bubble size decreases with frother concentration and bubble velocity acceleration height also decreases with bubble size. Jordan et al. (1993) found that these two trends become less effective with the addition of surfactant. The explanation was that the bubbles become progressively covered with surfactant as they rose until surfactant saturation was reached. The rising distance to reach surfactant saturation decreases with increasing concentration of surfactant. Warszynski et al. (1996) demonstrated a non-equilibrium distribution of surfactant over the surface of the bubbles during the lifetime of bubbles with different rising distance. During movement of bubbles in liquid, the surfactant molecules adsorbed on the surface of bubbles will be swept away to a low surface coverage region. Therefore, a gradient of surface coverage is established. The non-uniformly distributed surfactants will tend to diffuse from the region with high surface coverage to low coverage, and the surfactant diffusion is balanced by viscous tangential stress on the interface.

\subsubsection{Velocity Profile in Liquid}

The terminal velocity of a bubble depends upon the frother concentration and frother type. The rising velocity of a bubble in surfactant solution decreases with increasing concentration until a minimum velocity is reached, and further increase in surfactant concentration does not affect the velocity (Zhou et al., 1992). Fdhila and Duineveld (1996) measured the velocity at a given height above the point of release and found a similar concentration effect.

Mclaughlin (1996) modeled single-bubble motion using the insoluble surfactant model and numerical solution of the free boundary problem, the bubble Reynolds number, Re, ranged up to nearly 600. Sam et al. (1996) measured the local (near instantaneous) velocity as a function of height. These investigators found that the velocity of a bubble in a column of liquid has up to three stages: acceleration to a maximum followed by deceleration to a constant velocity. To estimate the velocity in pure water, Sam et al. (1996) proposed that since the acceleration period is so short $(<<1 \mathrm{~s})$ that the maximum velocity attained can be taken as a measure of the terminal velocity. For surfactant solutions, the terminal velocity is equated with a constant velocity. Similarly, the velocity was first increased to the maximum and then decreased, and if time was sufficient, it reached the third stage, a constant or terminal velocity stage. Time to reach the terminal velocity depends on frother type and concentration. The authors compared three different frothers in their test. It was found that, at the surfactant concentration of $30 \mathrm{ppm}$, the terminal velocity of a bubble with a $2.7 \mathrm{~mm}$ diameter gave the terminal velocity of $18 \mathrm{~cm} / \mathrm{s}$ in pine oil solution, $22 \mathrm{~cm} / \mathrm{s}$ in MIBC solution, $21 \mathrm{~cm} / \mathrm{s}$ in Dowfroth 
250 , and $26 \mathrm{~cm} / \mathrm{s}$ in distilled water respectively. In all of hem, time for the bubble to reach the terminal velocity is very short $(<1$ second). If the concentration is increased, the terminal velocity will decrease and the time to reach the constant velocity will decrease. If the concentration is maintained at $30 \mathrm{ppm}$, the bubble size is decreased, and thus the terminal velocity is decreased. For example, the terminal velocity of a bubble in MIBC solution decreased from $22 \mathrm{~cm} / \mathrm{s}$ to $12 \mathrm{~cm} / \mathrm{s}$ when bubble size was reduced from $2.7 \mathrm{~mm}$ to $0.9 \mathrm{~mm}$. They termed this as "velocity profile" and examples of this are illustrated in Figure 2-1. It should be noted that, in their test experiments, the bubble generation frequency selected was very low $(<80$ bubbles/min) to guarantee the velocity is independent of frequency.

Zhang and Finch (1999) applied the same reasoning in their determination of the terminal velocity of a single bubble in distilled water and in surfactant solution. They found little difference of terminal velocity between distilled water and low concentration $(<1 \mathrm{ppm})$. The acceleration period was sufficiently short. Thus, the maximum velocity in the profile was a good measurement of the terminal velocity in distilled water.

From the above it is concluded that the rising velocity of a single bubble changes with the properties of the fluid, the concentration of frother, bubble size and time. In a surfactant solution, the velocity profile exists. 


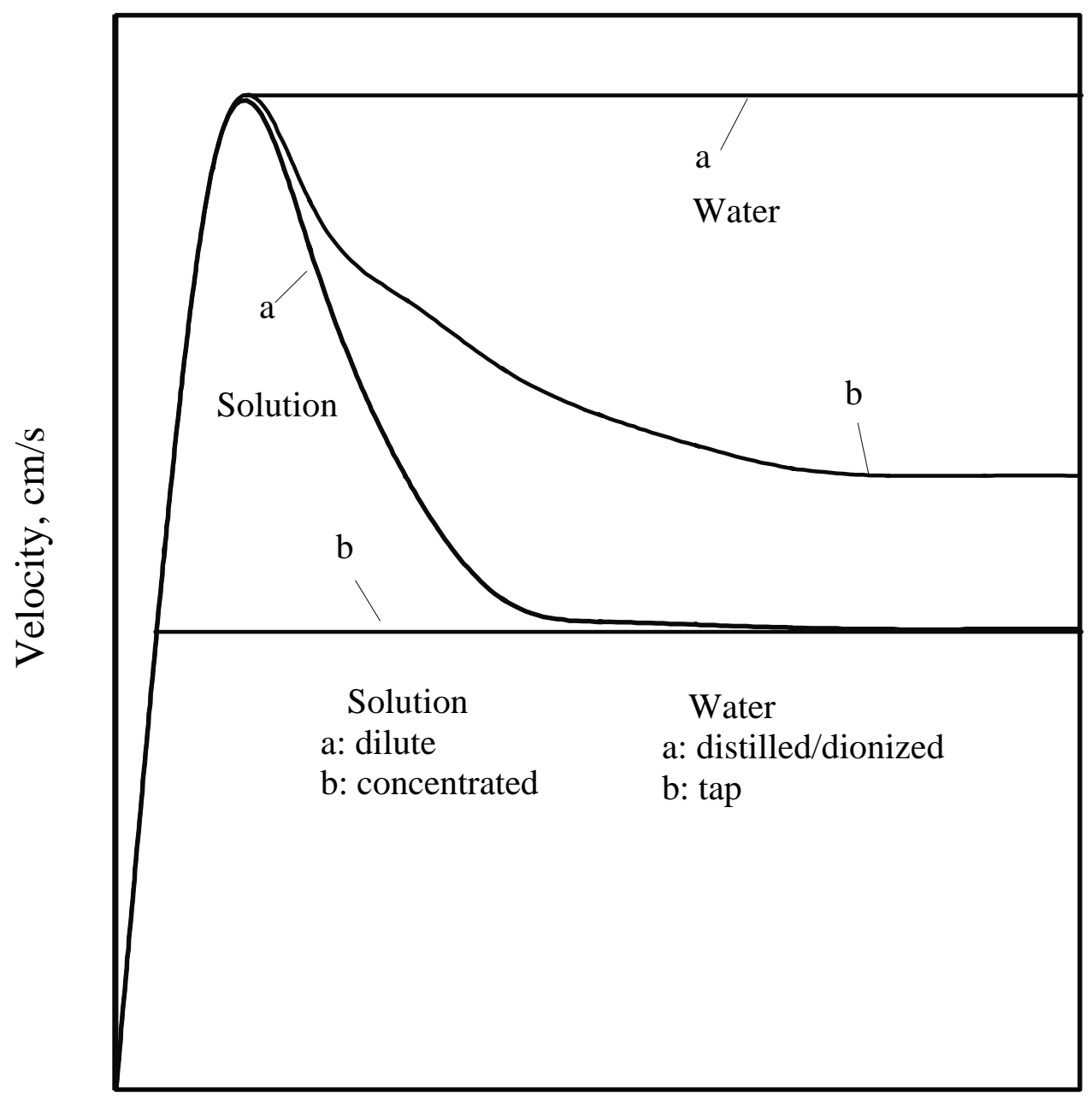

Height, cm

Figure 2-1 Typical single bubble velocity profiles 


\section{CHAPTER 3}

\section{EXPERIMENT}

\subsection{Solvents and Apparatus for Frothability Evaluation}

The solvents used in this evaluation are summarized in Table 3-1. The detailed physical and chemical properties of the solvents are given in Appendix A. Among fourteen solvents used in this evaluation, seven of them are glycol ethers. Solvents 3, 4, 5 and 6 are almost pure glycol ethers and Solvents 6,7 and 9 are the mixtures of glycol ethers. Solvents 1, 7 and 10 are alcohol mixtures, while Solvent 12 is acetone polymer. The reference frothers selected are MIBC (Solvent 2), Dow Froth 250 (Solvents 13) and Dow Froth 150 (Solvent 14).

Figure 3-1 shows the schematic diagram of a froth column meter. The column is made of $56 \mathrm{~mm}$ ID and $1.5 \mathrm{~m}$ height plexiglass cylindrical tube. The froth is generated by aerating a solution of solvent using a fritted glass disc (sparger) at the bottom of the froth column. The fritted glass has $20 \mathrm{~mm}$ diameter and pore size of $40-60 \mu \mathrm{m}$. The compressed air from the building is used in the experiment. The airflow rate is initially controlled by a shut-off valve and a pressure gauge. The air is further passed through the drierit absorbent, sulfuric acid, water and cotton traps to remove the impurity and moisture present in the building air. A flow meter with a precision needle valve is used to control the airflow rate into the froth column. A scale is attached to the froth column to measure the collapse of froth layers as a function of time.

To start the test, glass column (56 mm ID) is filled with 2 liters of distilled water. The initial height of liquid in the column, $\mathrm{H}_{\mathrm{i}}$, is recorded. A small amount of compressed air is then introduced to flush out the water trapped in the fritted glass disc. Predetermined amount of solvent $(0-300 \mathrm{ppm})$ is added to the distilled water from the top of column using a syringe. The needle valve of the flowmeter is set to a predetermined air flow rate $(0-2.5 \mathrm{~L} / \mathrm{min})$. When the froth height reaches the equilibrium, the total froth height (maximum height of froth), $\mathrm{H}_{\mathrm{f}}$, is recorded. The froth volume, which is froth height, $\mathrm{h}$, times the cross sectional area of the column, $\mathrm{A}$, is measured to determine the frothability of the solutions of solvents at different concentration levels and aeration rates. As illustrated in Figure 3-2, the froth height, $h$, is the summation of froth and bubbles trapped in the liquid per unit cross sectional area of column, or the difference between total froth height and initial liquid height.

$$
\mathrm{H}=\mathrm{H}_{\mathrm{f}}-\mathrm{H}_{\mathrm{i}}
$$

\subsection{Experimental Procedures for Frothability Measurement}

For measuring the froth collapse rate or bubble coalescence rate, the aeration is turned-off, while simultaneously starting to record the changes of the froth height with time until the froth layer disappears. The bubble coalescence proceeds gradually from the top of froth layer to the interface of air and solution. The froth collapse rates as a function of solvent concentrations and aeration rates are determined. When the shut-off valve is closed, there is a residual air remained in the solution. This residual air will 
Table 3-1 Solvents Identification Numbers and Components

\begin{tabular}{|c|c|c|}
\hline $\begin{array}{l}\text { Solvent } \\
\text { ID }\end{array}$ & Name & Component \\
\hline 1 & $\begin{array}{l}\text { UNFLITERED } \\
\text { TAFT OXO MIXTURE }\end{array}$ & $\begin{array}{l}\text { Isobutanol }<=50 \% \text {, } \\
\text { 2-ethyl-3-hydroxyhexyl ester, butanoic acid etc. }\end{array}$ \\
\hline 2 & $\begin{array}{l}\text { METHYL AMYL } \\
\text { ALCOHOL }\end{array}$ & $\begin{array}{l}\text { Methyl isobutyl carbinol, } \\
\left(\mathrm{CH}_{3}\right)_{2} \mathrm{CHCH}_{2} \mathrm{CH}(\mathrm{OH}) \mathrm{CH}_{3} \\
100 \% \quad 102.18 \mathrm{mg} / \mathrm{mol}\end{array}$ \\
\hline 3 & BUTOXYTRIGLYCOL & $\begin{array}{l}\text { Triethylene glycol monobutyl ether } \\
\mathrm{CH}_{3} \mathrm{CH}_{2} \mathrm{CH}_{2} \mathrm{CH}_{2} \mathrm{O}\left(\mathrm{CH}_{2} \mathrm{CH}_{2} \mathrm{O}\right)_{3} \mathrm{H} \\
85-100 \% 206.3 \mathrm{~g} / \mathrm{mol}\end{array}$ \\
\hline 4 & ETHOXYTRIGLYCOL & $\begin{array}{l}\text { Triethylene glycol monoethyl ether } \\
\mathrm{CH}_{3} \mathrm{CH}_{2} \mathrm{O}\left(\mathrm{CH}_{2} \mathrm{CH}_{2} \mathrm{O}\right)_{3} \mathrm{H} \\
85-90 \% \quad 178 \mathrm{~g} / \mathrm{mol}\end{array}$ \\
\hline 5 & $\begin{array}{l}\text { HEXYL CARBITOL } \\
\text { SOLVENT }\end{array}$ & $\begin{array}{l}\text { Diethylene glycol monohexyl ether } \\
\mathrm{CH}_{3} \mathrm{CH}_{2} \mathrm{CH}_{2} \mathrm{CH}_{2} \mathrm{CH}_{2} \mathrm{CH}_{2} \mathrm{O}\left(\mathrm{CH}_{2} \mathrm{CH}_{2} \mathrm{O}\right)_{2} \mathrm{H} \\
97-100 \% \quad 190.3 \mathrm{~g} / \mathrm{mol}\end{array}$ \\
\hline 6 & $\begin{array}{l}\text { ECOSOFT(TM) SOLVENT } \\
\text { PH }\end{array}$ & $\begin{array}{l}\text { Glycol ethers mixture } \\
\mathrm{CH}_{3} \mathrm{CH}_{2} \mathrm{CH}_{2} \mathrm{CH}_{2} \mathrm{CH}_{2} \mathrm{CH}_{2} \mathrm{O}\left(\mathrm{CH}_{2} \mathrm{CH}_{2} \mathrm{O}\right)_{3} \mathrm{H} \\
\text { Triethylene monohexyl ether } 40-85 \% \\
\text { Polyethylene glycol monohexyl ether } 5-25 \% \\
\text { Diethylene glycol monohexyl ether }<25 \%\end{array}$ \\
\hline 7 & $\begin{array}{l}\text { FILTERED } \\
\text { TAFT OXO MIXTURE }\end{array}$ & $\begin{array}{l}\text { Isobutanol }<=50 \% \text {, } \\
\text { 2-ethyl-3-hydroxyhexyl ester, butanoic acid etc. }\end{array}$ \\
\hline 8 & $\begin{array}{l}\text { ECOSOFT(TM) SOLVENT } \\
\text { PB }\end{array}$ & $\begin{array}{l}\text { Glycol ethers mixture } \\
\text { Polyethylene glycol monobutyl ether 98-99\% }\end{array}$ \\
\hline 9 & $\begin{array}{l}\text { ECOSOFT(TM) SOLVENT } \\
\text { PE }\end{array}$ & $\begin{array}{l}\text { Glycol mixture } \\
\text { Polyethylene glycol monoethy ether } 50-90 \% \\
\text { Triethylene glycol monoethy ether }<25 \%\end{array}$ \\
\hline 10 & $\begin{array}{l}\text { TEXAS CITY OXO } \\
\text { MIXTURE }\end{array}$ & $\begin{array}{l}\text { 2-Ethyl hexyl alcohol, octyl alcohol, butanol, } 2 \\
\text { methyl butanol etc. }\end{array}$ \\
\hline 11 & $\begin{array}{l}\text { BUTYL CARBITOL } \\
\text { (TM) SOLVENT }\end{array}$ & $\begin{array}{l}\text { Diethylene glycol monobutyl ether } \\
\mathrm{C}_{3} \mathrm{HCH}_{2} \mathrm{CH}_{2} \mathrm{CH}_{2} \mathrm{O}\left(\mathrm{CH}_{2} \mathrm{CH}_{2} \mathrm{O}\right)_{2} \mathrm{H} \\
99-100 \%\end{array}$ \\
\hline 12 & $\begin{array}{l}\text { ACETONE POLYMER } \\
\text { (CDTA REGULATED) }\end{array}$ & NA \\
\hline 13 & DOW FROTH 250 & $\mathrm{CH}_{3} \mathrm{O}\left(\mathrm{CHCH}_{3} \mathrm{CH}_{2} \mathrm{O}\right)_{4} \mathrm{H}$ \\
\hline 14 & DOW FROTH 150 & $\mathrm{CH}_{3} \mathrm{O}\left(\mathrm{CHCH}_{3} \mathrm{CH}_{2} \mathrm{O}\right)_{2} \mathrm{H}$ \\
\hline
\end{tabular}




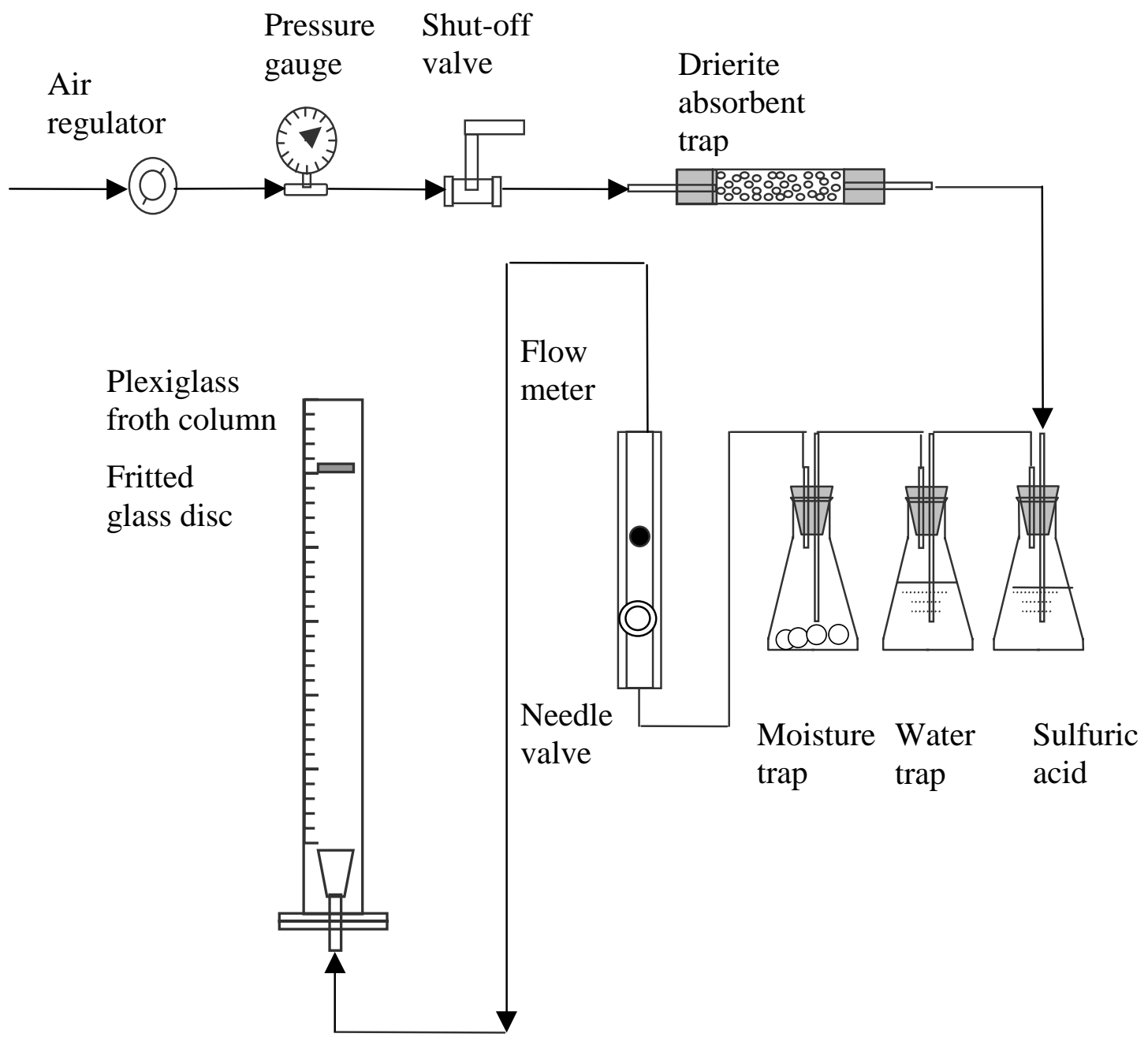

Figure 3-1 Schematic diagram of froth column meter 


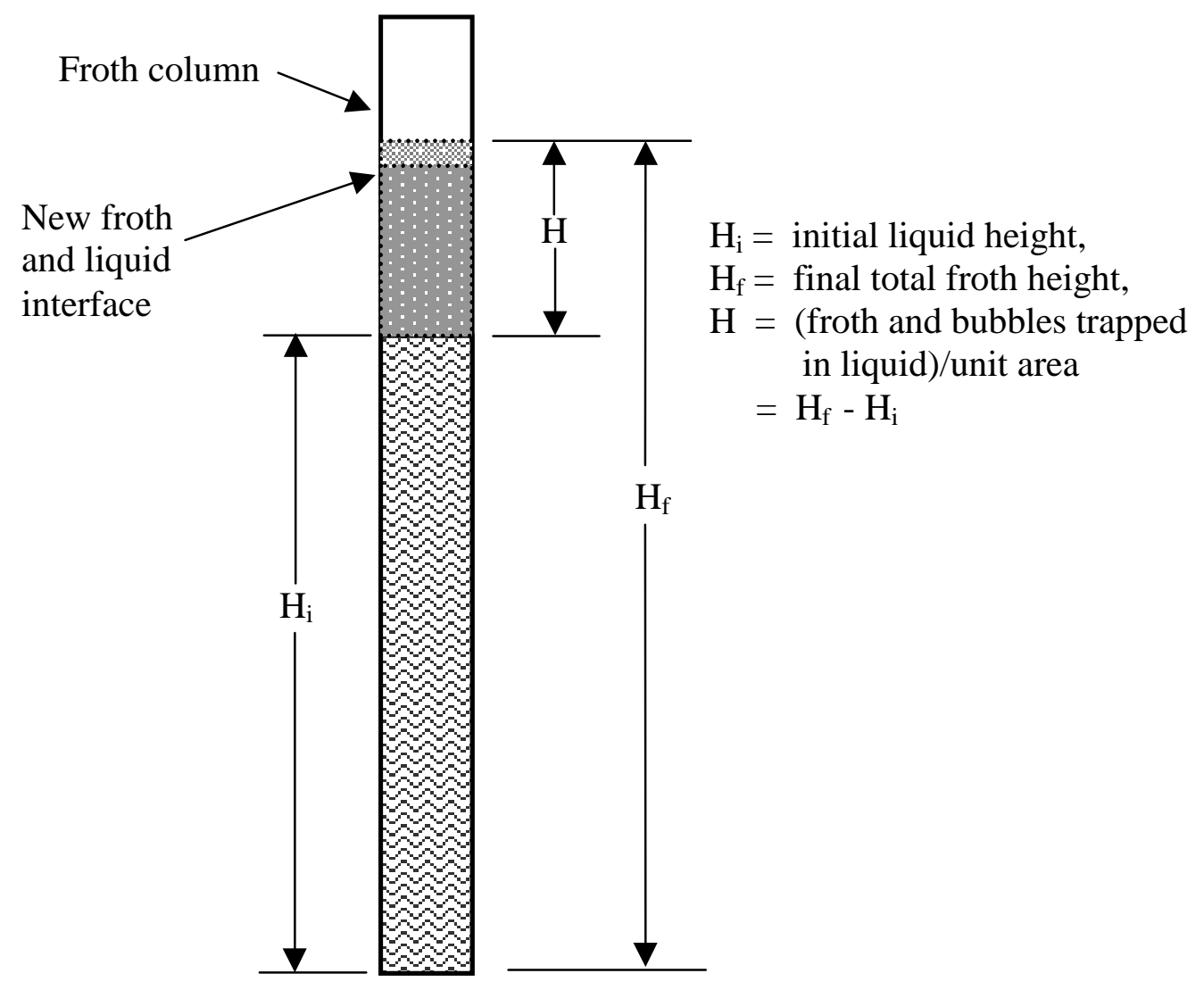

Figure 3-2 Froth and liquid interface in froth column meter 
continue to support the froth layer until the air completely evolves off the column. Five repetitive runs are made for each solvent concentration level and airflow rate. At the end of each test, the froth column and the sparger is thoroughly cleaned with water, and rinsed with distilled water. All the experiment is conducted at a room temperature of 20 ${ }^{\circ} \mathrm{C}$.

\subsection{Coal Sample and Fine coal flotation}

The coal used in this study is Pittsburgh Seam coal from Bentleyville, Green County, PA. Numerous studies by many investigators shows that Pittsburgh Seam coal is an appropriate coal for reagent evaluation and comparisons because of its typical flotation characteristics of Bituminous coal. The raw coal, as received, is air dried and crushed by a jaw crusher, and then screened through a $5 \mathrm{~mm}$ sieve, minus $5 \mathrm{~mm}$ size fraction is further ground in a pulverizing mill. The grinding mill product, which has a size distribution given in Table 3-2, is split subsequently into $180 \mathrm{~g}$ size samples and the split coal samples are stored individually in the plastic bag and placed in a freezer until use. The ash content of raw coal, determined by using ASTM method, came to be $26.35 \%$.

Denver laboratory flotation machine, model D-12, with a $2000 \mathrm{~mL}$ flotation cell equipped with an automated double froth paddles and froth removal system is used for the fine coal flotation. The paddle rotation speed is adjusted to $35 \mathrm{rpm}$ using a constant torque speed controller and a gear motor. Spraying water is used to wash off the froth on the paddles and the sides of the cell during flotation.

A $180 \mathrm{~g}$ coal sample is conditioned in $1000 \mathrm{~mL}$ distilled water at impeller speed of $1200 \mathrm{rpm}$ for 6 minutes. After initial conditioning, the collector, kerosene, is added and conditioned for 3 minutes. The frother is then added, followed by another 1 minute conditioning period and addition of $800 \mathrm{~mL}$ distilled water. Futher conditioning for 1 minute is done, after which, the air valve and the paddles are turned on simultaneously for flotation. The volumetric air flow rate kept at is $1.42 \mathrm{~L} / \mathrm{min}$./L cell volume and the impeller speed at $1200 \mathrm{rpm}$.

Table 3-2 Size distribution of flotation feed

\begin{tabular}{|c||c|c||}
\hline $\begin{array}{c}\text { Particle size } \\
(\mu \mathrm{m})\end{array}$ & Wt\% & Cum. Wt\% Retained \\
\hline \hline+212 & 13.28 & 13.28 \\
$125-212$ & 21.09 & 34.37 \\
$106-125$ & 10.07 & 44.44 \\
$75-106$ & 9.02 & 53.46 \\
$43-75$ & 26.65 & 80.11 \\
$37-43$ & 16.94 & 97.05 \\
-37 & 2.95 & 100.00 \\
\hline
\end{tabular}

The froth is collected at intervals of 20, 40, 60, 120, and 180 seconds. The concentrates and the tails are vacuum filtered using Whatman No. 42 filter paper, air 
dried overnight, and further dried in an oven at $110^{\circ} \mathrm{C}$. The dried samples are weighed, and their ash contents are determined. The froth concentrate is then sieved to determine the particle size distribution.

The combustible recoveries and ash contents of clean coal products as a function of time are determined for different collector and frother dosages. The combustible recovery, $\mathrm{R}_{\mathrm{c}}$, and ash recovery, $\mathrm{R}_{\mathrm{A}}$ are defined as

$$
\begin{aligned}
\mathrm{R}_{\mathrm{c}} \% & =\frac{\mathrm{Y}_{\mathrm{c}}\left(100-\mathrm{A}_{\mathrm{C}}\right)}{\mathrm{Y}_{\mathrm{f}}\left(100-\mathrm{A}_{\mathrm{f}}\right)} \times 100 \% \\
\mathrm{R}_{\mathrm{A}} \% & =\frac{\mathrm{Y}_{\mathrm{c}} \mathrm{A}_{\mathrm{c}}}{\mathrm{Y}_{\mathrm{f}} \mathrm{A}_{\mathrm{f}}} \times 100 \%
\end{aligned}
$$

where $Y_{f}$ and $Y_{c}$ are the weights of feed and product in percentage, and $A_{f}$ and $A_{c}$ are the ash contents of feed and product in percentage respectively.

The performance of fine coal flotation is evaluated using flotation rate constant and the ultimate recovery. The following expression proposed by Huber-Penu et al. (1976) is used to describe the combustible and ash recovery of flotation product as a function of time.

$$
\mathrm{R}=\mathrm{R}_{\mathrm{m}}\left[1-\left(\frac{1}{\mathrm{Kt}}(1-\exp (-\mathrm{Kt}))\right)\right]
$$

where $\mathrm{R}$ represents the cumulative recovery of some component in the product at time $\mathrm{t}$, $\mathrm{R}_{\mathrm{m}}$ is the ultimate (equilibrium) recovery of some component at infinite flotation time, and $\mathrm{K}$ is rate constant of the recovery.

To determine the parameters, $K$ and $R_{m}$ in Equation (3-3), a non-line parameter estimation based on Conjugate gradient method, in $\mathrm{C}$ source codes, is developed and used (see Appendix C). The criterion used for estimating parameter values is the minimization of the absolute sum of the squares of the difference between observed and calculated values of some component recovery at a given type and concentration of frother.

$$
\min \left\{\operatorname{Sum}=\sum_{\mathrm{i}=1}^{\mathrm{n}}\left[\left(\mathrm{R}_{\text {obs }}\right)_{\mathrm{i}}-\left(\mathrm{R}_{\text {calc }}\right)_{\mathrm{i}}\right]^{2}\right\}
$$

where $R_{o b s}$ is the observed value of some component recovery, $R_{\text {calc }}$ is the calculated value of some component recovery, and $\mathrm{n}$ is the number of experimental data points. 


\section{CHAPTER 4}

\section{RESULTS AND DISCUSSION}

\subsection{Terminal Rising Velocity of Bubbles}

For a fluid with a Reynolds number less than 20000, the drag coefficient $C_{d}$ can be expressed as (Schlichting, 1979):

$$
\begin{gathered}
C_{d}=\frac{24}{\operatorname{Re}}+\frac{6}{1+\sqrt{\operatorname{Re}}}+0.4 \\
0 \leq \operatorname{Re} \leq 2 \times 10^{5}
\end{gathered}
$$

For a fixed bubble size and a constant aeration rate $\mathrm{Q}$, the equation of a motion for a bubble in the column is

$$
\begin{aligned}
\mathrm{m} \frac{\mathrm{d} v}{\mathrm{dt}} & =\frac{4}{3} \pi \mathrm{r}^{3} \rho_{\mathrm{L}}-\frac{1}{2} \rho_{\mathrm{L}} v^{2} \pi(\mathrm{ra})^{2} \mathrm{C}_{\mathrm{d}} \\
\mathrm{m} & =\frac{4}{3} \pi \mathrm{r}^{3}\left(\mathrm{a}^{3}-1\right) \rho_{\mathrm{L}}
\end{aligned}
$$

where $v$ is the rising velocity of a bubble in column, $\mathrm{cm} / \mathrm{s}$, a is the ratio of thickness of boundary layer on bubble to the diameter of bubble, $\mathrm{cm}, \mathrm{r}$ is the radius of the bubble, $\mathrm{cm}$, $\mathrm{m}$ is the material quantity, and $\rho_{L}$ is the density of liquid in column, $\mathrm{g} / \mathrm{cm}^{3}$.

$$
\begin{aligned}
\frac{4}{3} \pi r^{3}\left(a^{3}-1\right) \rho_{L} \frac{d v}{d t} & =\frac{4}{3} \pi r^{3} \rho_{L}-\frac{1}{2} \rho_{L} v^{2} \pi(r a)^{2} C_{d} \\
\frac{d v}{d t} & =\frac{\rho_{L}}{\left(a^{3}-1\right) \rho_{L}} g-\frac{3 a^{2}}{8 r\left(a^{3}-1\right)} C_{d} v^{2} \\
\frac{d v}{d t} & =\frac{g}{\left(a^{3}-1\right)}-\frac{3 a^{2}}{8 r\left(a^{3}-1\right)} C_{d} v^{2}
\end{aligned}
$$

when $\frac{\mathrm{d} v}{\mathrm{dt}}=0, v$ equals terminal velocity $\mathrm{V}_{\mathrm{t}}$ of the bubble in liquid.

$$
V_{t}=\sqrt{\frac{8 r g}{3 a^{2} C_{d}}}
$$

\subsection{Retention time}

From Equation (4-4) and Figure 2-1, the velocity of a bubble in a liquid of column can be considered as a constant, which is approximately the terminal velocity. The retention time for a bubble in liquid can be estimated using

$$
\mathrm{L} \approx \mathrm{V}_{\mathrm{t}} \mathrm{T}
$$


$\mathrm{L}$ is the liquid height in a froth column meter, $98.8 \mathrm{~cm}, \mathrm{~T}$ is the average retention time of a bubble in the liquid of a 2-inch ID column, s. Since $\mathrm{T}$ is also equal to the average retention time of froth in liquid column, the following equation is used to estimate $\mathrm{T}$

$$
\mathrm{T}=\frac{\mathrm{d}(\text { froth volume })}{\mathrm{d}(\text { air volume })}=\frac{\mathrm{d}\left(\mathrm{H} \times \pi \times 2.54^{2}\right)}{\mathrm{d}\left(\mathrm{Q} \times \frac{1000}{60}\right)} \approx 1.215 \frac{\mathrm{dH}}{\mathrm{dQ}}
$$

where, $\mathrm{H}$ is the froth height in column, $\mathrm{cm}$, and $\mathrm{Q}$ is aeration rate, $\mathrm{L} / \mathrm{min}$. Substituting the Equation (4-4) and (4-6) into Equation (4-5) yield

$$
\mathrm{L}=98.8 \mathrm{~cm}=\mathrm{V}_{\mathrm{t}} \mathrm{T}=\sqrt{\frac{8 \mathrm{rg}}{3 \mathrm{a}^{2} \mathrm{C}_{\mathrm{d}}}} \times 1.215 \frac{\mathrm{dH}}{\mathrm{dQ}}=62.13 \sqrt{\frac{\mathrm{r}}{\mathrm{a}^{2} \mathrm{C}_{\mathrm{d}}}} \frac{\mathrm{dH}}{\mathrm{dQ}}
$$

Substituting Equation (4-1) into Equation (4-7) yields

$$
\frac{\mathrm{dH}}{\mathrm{dQ}}=1.59 \frac{\mathrm{a}}{\sqrt{\mathrm{r}}} \sqrt{\mathrm{C}_{\mathrm{d}}}=1.59 \frac{\mathrm{a}}{\sqrt{\mathrm{r}}} \sqrt{\frac{24}{\mathrm{Re}}+\frac{6}{1+\sqrt{\mathrm{Re}}}+0.4}
$$

The Reynolds number, Re, of a bubble in the column froth meter is

$$
\operatorname{Re}=\frac{2 \mathrm{r} \mathrm{V}_{\mathrm{g}} \rho_{\mathrm{L}}}{\mu}
$$

where $\mathrm{V}_{\mathrm{g}}$ is the velocity of bubble, $\mathrm{cm} / \mathrm{s}$. Thus

$$
\begin{aligned}
& \mathrm{V}_{\mathrm{g}}=\frac{\mathrm{Q}}{\pi \times \mathrm{A}^{2}}=\frac{\mathrm{Q} \times 1000}{60 \times 3.14 \times 2.54^{2}}=0.823 \mathrm{Q} \\
& \mathrm{Re}=\frac{2 \mathrm{r} \times 0.823 \mathrm{Q} \times 1}{0.01}=0.823 \mathrm{Q} \\
& \frac{\mathrm{dH}}{\mathrm{dQ}}=1.59 \frac{\mathrm{a}}{\sqrt{\mathrm{r}}} \sqrt{\frac{24}{164.6 \mathrm{Qr}}+\frac{6}{1+\sqrt{164.6 \mathrm{Qr}}}+0.4}
\end{aligned}
$$

From Equation (4-9), if the radius of a bubble, $r$, is given, the changes of froth height, $\mathrm{H}$, with the aeration rate, $\mathrm{Q}$, can be calculated. However, the bubble average size in the column changes during its upward movement in column because of bubble coalescence. In order to investigate the changing of bubble size during coalescence, a step growth model regarding the bubble coalescence is established (see Appendix B). Based on the step growth model of bubble, the following expression is obtained

$$
\frac{1}{[\mathrm{~B}]}-\frac{1}{[\mathrm{~B}]_{\mathrm{O}}}=\mathrm{K}_{\mathrm{c}} \mathrm{t}
$$

where $[\mathrm{B}]$ is the number of bubbles per unit volume in column involved in the process of bubble coalescence, $[\mathrm{B}]_{\mathrm{O}}$ is initial number of bubbles per unit volume in column at the beginning of the process of bubble coalescence, $\mathrm{K}_{\mathrm{c}}$ is the bubble collapse rate constant, and $t$ is the time, s. If $\mathrm{Q}_{\mathrm{T}}$ is the froth volume per unit volume in column, then $[\mathrm{B}]$ and $[\mathrm{B}]_{\mathrm{o}}$ can be expressed as: 


$$
\begin{gathered}
{[\mathrm{B}]=\frac{\mathrm{Q}_{\mathrm{T}}}{\frac{4}{3} \pi \mathrm{r}_{\text {ave }}{ }^{3}}} \\
{[\mathrm{~B}]_{\mathrm{o}}=\frac{\mathrm{Q}_{\mathrm{T}}}{\frac{4}{3} \pi \mathrm{r}_{\text {aveo }}{ }^{3}}}
\end{gathered}
$$

where $r_{\text {ave }}$ is the average bubble radius involved in the process of bubble coalescence and $\mathrm{r}_{\text {aveo }}$ is the average bubble radius at the beginning of process of bubble coalescence respectively.

Substituting Equations (4-11) and (4-12) into Equation (4-10) yields

$$
\frac{\mathrm{Q}_{\mathrm{T}}}{\frac{4}{3} \pi \mathrm{r}_{\text {ave }}{ }^{3}}-\frac{\mathrm{Q}_{\mathrm{T}}}{\frac{4}{3} \pi \mathrm{r}_{\text {aveo }}{ }^{3}}=\mathrm{K}_{\mathrm{C}} \mathrm{t}
$$

Equation (4-8) shows that the sizes of the bubble are dependent upon the froth volume trapped in the column, $\mathrm{Q}_{\mathrm{T}}$, bubble coalescence constant, $\mathrm{K}_{\mathrm{c}}$, and time, t. Figure 4-1 shows that the bubble retention time, $\mathrm{A} \frac{\mathrm{dH}}{\mathrm{dQ}}$, decreases with increasing bubble size and aeration rate. If the aeration rate is over $1.5 \mathrm{~L} / \mathrm{min}$, its effect on retention time diminishes.

\subsection{Definition of Initial Dynamics Froth Index (IDFI)}

\subsubsection{Ultimate froth height}

Malysia et al. (1987) studied the frothability of three alcohols including n-butanol, npentanol and $n$-hexanol solutions in a column froth meter. A parameter, retention time, $\mathrm{Rt}$, is introduced to describe the frothability of these alcohol solutions. The retention time, Rt, seconds, is defined as a slope of the linear part of the relationship, $\mathrm{Vg}=\mathrm{f}(\mathrm{Ug})$, where $\mathrm{Vg}, \mathrm{L}$, is the froth volume trapped in the liquid and $\mathrm{Ug}, \mathrm{L} / \mathrm{min}$, is the aeration rate.

$$
\mathrm{Rt}=\frac{\Delta \mathrm{Vg}}{\Delta \mathrm{Ug}} \times 60
$$

Figure 4-2 shows the relationship between the froth height and aeration rate for the distilled/deionized water in this study. The result shows a stable retention time value (the slope), which is independent of the gas flow rate and the geometry of the measuring column. Figure 4-3 shows that the system containing MIBC solution also has the linear relationship between the froth height and the aeration rate. The figure clearly shows that the slope depends upon the solvent concentration. For this study, the froth height is defined as froth volume divided by cross-sectional area of the column. However, the plots of froth height and aeration rate for polyglycol ether type solvent show a typical non-linear relationship as shown in Figure 4-4 for Butoxytriglycol (Solvent 3). The froth height increases with aeration rate, but this increase is not proportional to the 


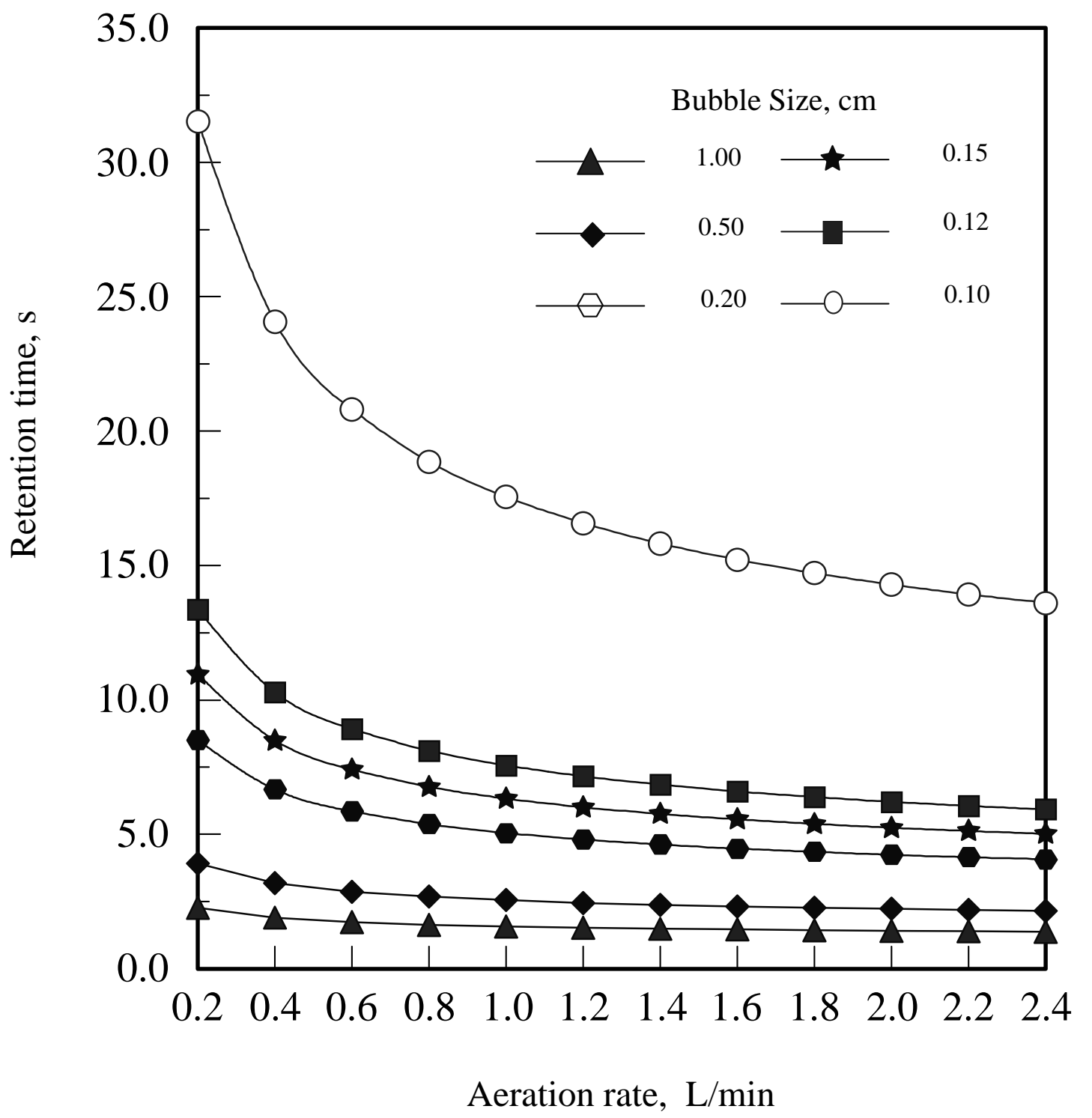

Figure 4-1 Dependence of retention time on aeration rate 


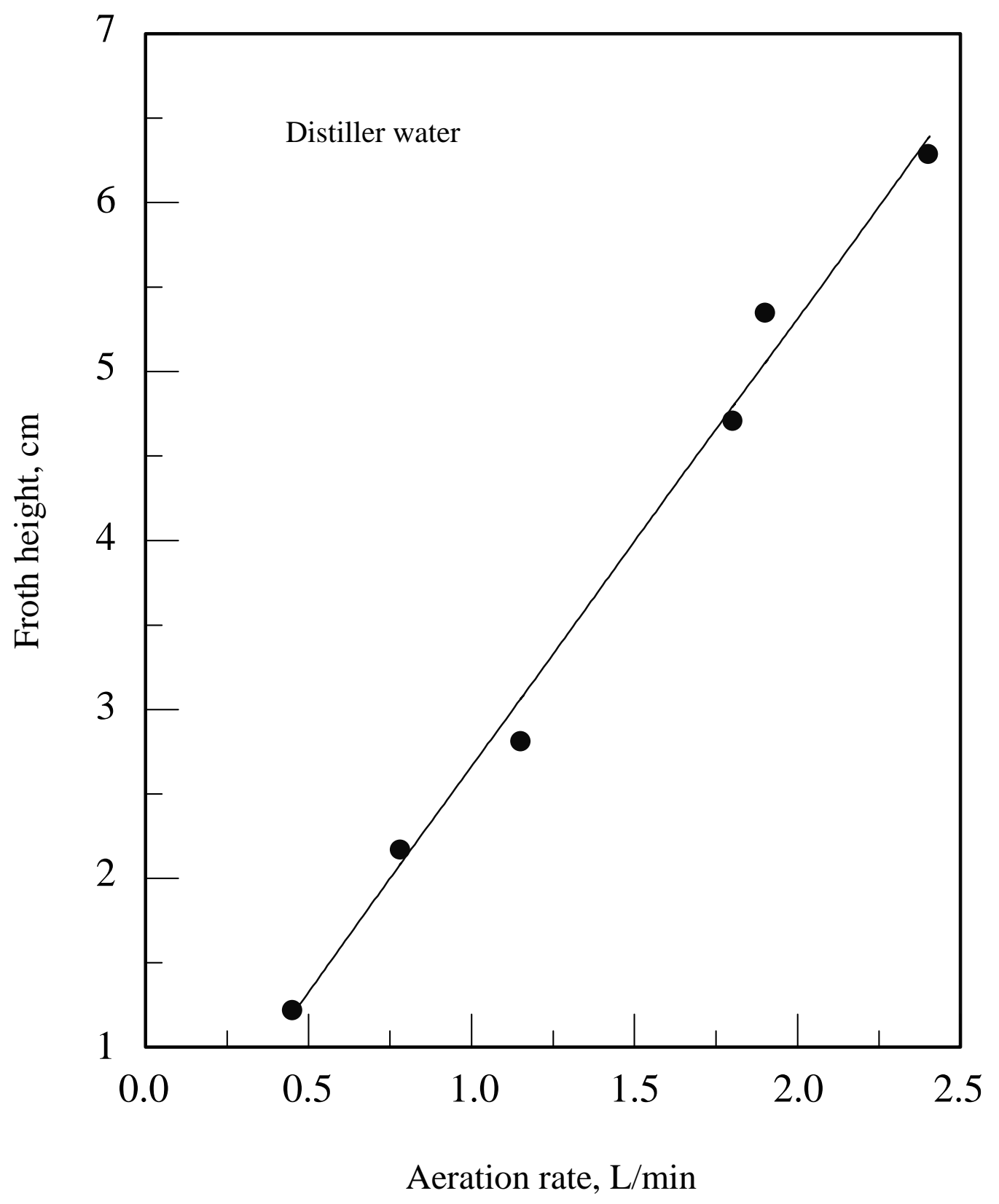

Figure 4-2 Froth height as a function of aeration rate in pure water 




Figure 4-3 Froth height as a function of aeration rate at various solvent concentrations (MIBC, Solvent 2) 


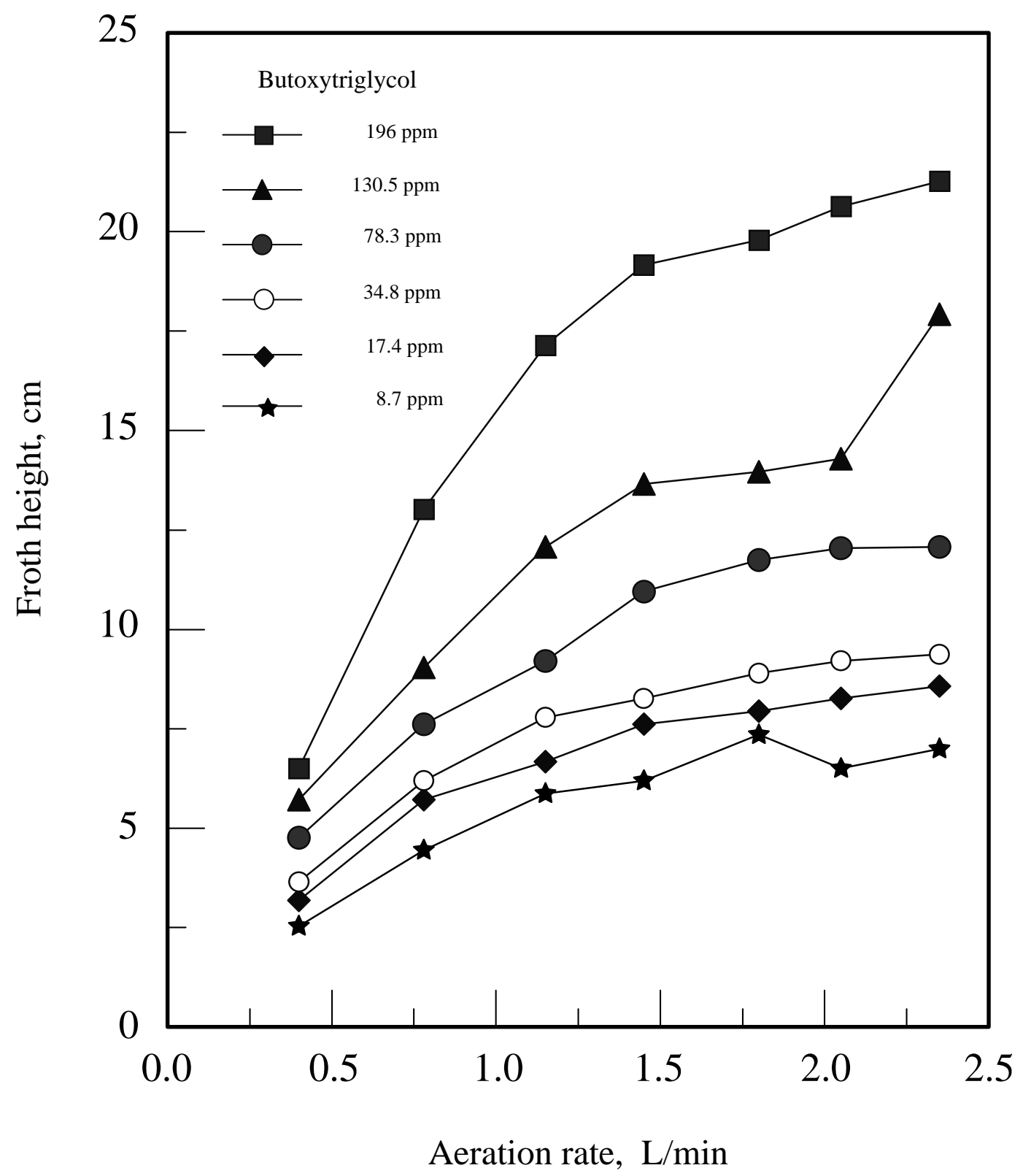

Figure 4-4 Froth height as a function of aeration rate at various solvent concentration (Butoxytriglycol, Solvent 3) 
corresponding increase in aeration rate. The growth of froth height slows down with increasing aeration rate until the froth height reaches a plateau, an ultimate froth height. The ultimate froth height increases with the solvent concentration and the aeration rate. Thus, to apply the concept linearity of retention time proposed by Malysa to describe the frothing characteristics of Polyglycol ethers type solvents is inappropriate.

The following mathematical model is used to describe the relationship of froth height and aeration rate at various solvent concentrations for each Solvent.

$$
\begin{aligned}
\mathrm{H} & =\mathrm{H}_{0}\left(1-\exp \left(-\mathrm{K}_{\mathrm{f}} \mathrm{Q}\right)\right) \\
\mathrm{AH} & =\mathrm{AH}_{0}\left(1-\exp \left(-\mathrm{K}_{\mathrm{f}} \mathrm{Q}\right)\right)
\end{aligned}
$$

where $\mathrm{H}$ is froth height, $\mathrm{cm}$, at aeration rate $\mathrm{Q}, \mathrm{mL} / \mathrm{min}, \mathrm{H}_{\mathrm{o}}$ is ultimate froth height, $\mathrm{K}_{\mathrm{f}}$ is a froth volume constant, and $\mathrm{H}_{\mathrm{o}}$ denotes the ultimate froth height, $\mathrm{cm}$, its value depends on solvent concentrations. $\mathrm{A}\left(=(\mathrm{D} / 2)^{2} \cdot \pi\right)$ is the cross sectional area of column, $\mathrm{cm}^{2}$. $\mathrm{AH}$ is the froth volume, mL. Equation (4-15) represents the change of froth height or froth volume with the aeration rate.

A non-linear parameter estimating method (See Appendix C) is employed to estimate the parameters of Equation (4-15). The results for Solvent 3 (Butoxytriglcol ether) at concentration of $17.4 \mathrm{ppm}$ and $78.3 \mathrm{ppm}$ as well as distilled water are exhibited in Figure 4-5. The ultimate froth height and the rate constant for all solvents tested at various concentration levels are given in Table 4-1.

\subsubsection{Initial Retention Time}

From Equation (4-15), the instantaneous retention time, Rt, can be derived

$$
\mathrm{Rt}=\frac{\mathrm{d}(\mathrm{AH})}{\mathrm{dQ}}=\mathrm{A} \frac{\mathrm{dH}}{\mathrm{dQ}}=\mathrm{AH}_{0} \mathrm{~K}_{\mathrm{f}} \exp \left(-\mathrm{K}_{\mathrm{f}} \mathrm{Q}\right)=\operatorname{IRT} \exp \left(-\mathrm{K}_{\mathrm{f}} \mathrm{Q}\right)
$$

when $\mathrm{Q} \rightarrow 0$, Rt approaches to a maximum value of $\mathrm{AH}_{0} \mathrm{~K}_{\mathrm{f}}$, which is initial retention time, IRT. IRT characterizes the frother at a given concentration only, but not frother itself. Dependencies of IRT values on the solvent concentration are presented in Figure 4-6a, 4$6 \mathrm{~b}$ and 4-6c for all tested solvents. IRT increases with the increasing of solvent concentration. Once the solvent concentration is above a certain level, IRT starts leveling off. It is also observed that some alcohol type solvents such as Solvent 2 (MIBC), Solvent 7 (alcohol mixture) and Solvent 1 (alcohol mixture), reach their initial retention time at a lower concentration level than the polyglycol ether type solvents.

IRT represents the largest value of the retention time at a given solvent concentration. A higher value of IRT means more time for a bubble to stay in the froth phase, and hence to maintain a higher froth height. Though IRT provides the information about the highest retention time of froth at a given concentration, it is not related to dynamic properties of frothing for forthers. IRT value, similar to Sun's (1953) frothability index, FI, characterizes only the solution with a given concentration but not the solvent itself. 


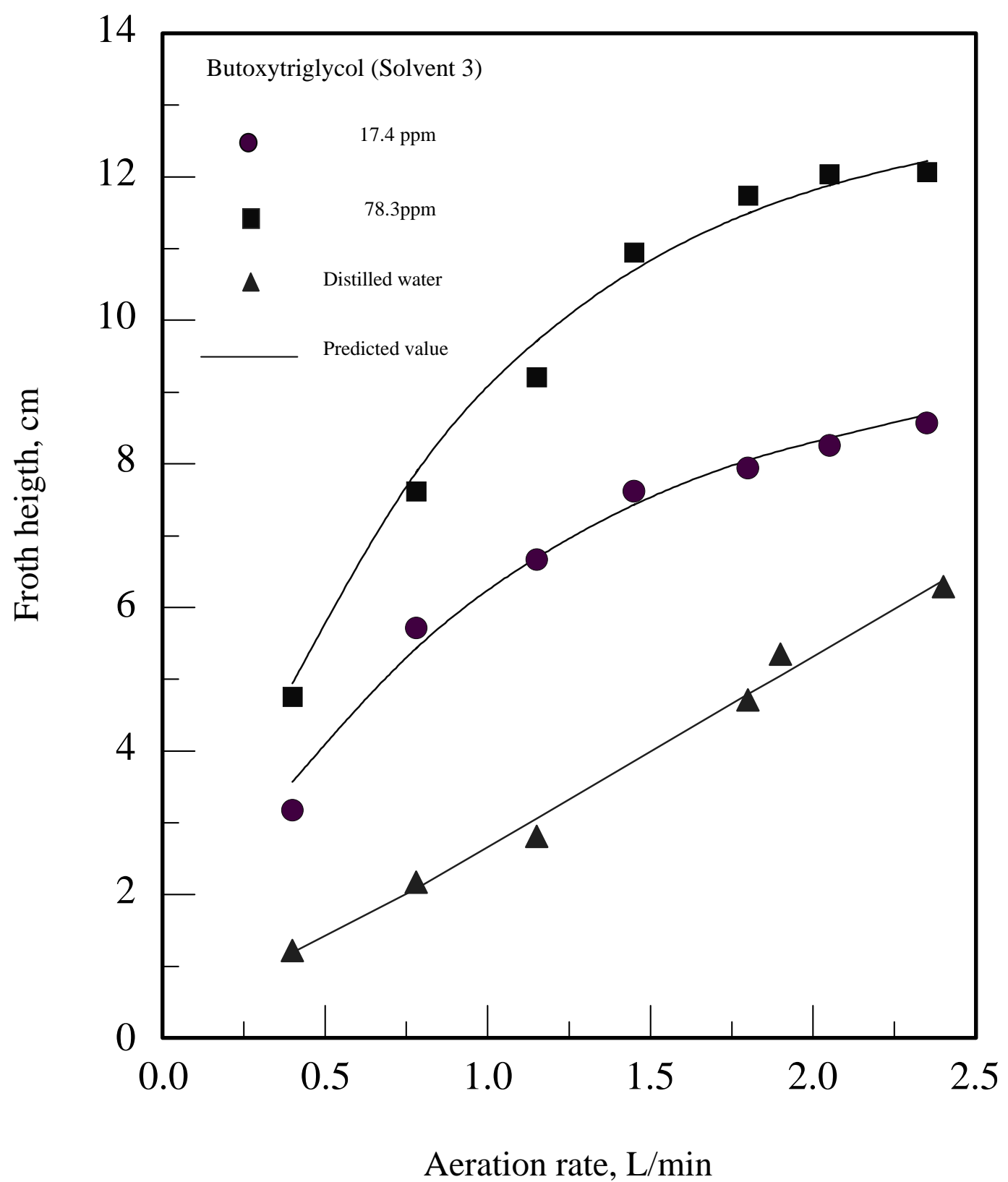

Figure 4-5 Froth height as a function of aeration rate for Butoxytriglycol (Solvent 3) 
Table 4-1 Ultimate froth height and volume constant as a function of frother concentration

\begin{tabular}{|c|c|c|c|c|c|}
\hline Solvent Name & $\begin{array}{c}\text { Concentrati } \\
\text { on ppm }\end{array}$ & $\begin{array}{l}\text { Ultimate } \\
\text { Froth } \\
\text { height, Ho } \\
\mathrm{cm}\end{array}$ & $\begin{array}{c}\text { Volume } \\
\text { Constant, } \\
\text { Ka } \\
\text { Min/L }\end{array}$ & $\begin{array}{l}\text { Sum of } \\
\text { Least } \\
\text { Squares } \\
\mathrm{cm}^{2}\end{array}$ & $\begin{array}{c}\text { Standard } \\
\text { Deviation } \\
\mathrm{cm}\end{array}$ \\
\hline \multirow[t]{2}{*}{ Solvent 1} & 7.00 & 10.48 & 0.68 & 13.46 & 1.64 \\
\hline & 14.00 & 10.82 & 0.87 & 8.01 & 1.27 \\
\hline \multirow{4}{*}{$\begin{array}{l}\text { Unfiltered TAFT } \\
\text { OXO Mixture }\end{array}$} & 28.00 & 11.45 & 0.95 & 5.99 & 1.09 \\
\hline & 53.00 & 13.01 & 1.22 & 1.81 & 0.60 \\
\hline & 105.00 & 13.80 & 1.28 & 4.72 & 0.97 \\
\hline & 158.00 & 14.05 & 1.69 & 0.85 & 0.41 \\
\hline \multirow[t]{2}{*}{ Solvent 2} & 6.00 & 11.34 & 0.36 & 4.86 & 3.12 \\
\hline & 12.00 & 12.22 & 0.55 & 2.82 & 2.37 \\
\hline \multirow{4}{*}{$\begin{array}{l}\text { Methyl Amyl Alcohol } \\
\text { (MIBC) }\end{array}$} & 24.00 & 13.73 & 0.60 & 3.02 & 2.46 \\
\hline & 52.00 & 15.76 & 0.55 & 45.74 & 3.02 \\
\hline & 75.00 & 19.18 & 0.43 & 90.23 & 4.39 \\
\hline & 121.00 & 19.72 & 0.44 & 109.40 & 4.68 \\
\hline \multirow[t]{2}{*}{ Solvent 3} & 8.70 & 7.46 & 0.95 & 3.10 & 0.79 \\
\hline & 17.40 & 8.90 & 0.97 & 3.35 & 0.82 \\
\hline \multirow[t]{4}{*}{ Butoxytriglycol } & 34.80 & 9.80 & 1.01 & 3.52 & 0.84 \\
\hline & 78.30 & 13.01 & 1.19 & 0.52 & 0.32 \\
\hline & 130.50 & 17.63 & 0.65 & 44.87 & 3.00 \\
\hline & 196.00 & 23.03 & 0.77 & 48.16 & 3.10 \\
\hline \multirow[t]{2}{*}{ Solvent 4} & 9.62 & 7.64 & 0.54 & 1.12 & 1.50 \\
\hline & 19.20 & 9.16 & 0.55 & 1.58 & 1.78 \\
\hline \multirow[t]{4}{*}{ Ethoxytriglycol } & 38.50 & 9.59 & 0.84 & 6.55 & 1.14 \\
\hline & 72.20 & 10.44 & 0.82 & 8.34 & 1.29 \\
\hline & 144.30 & 12.11 & 0.82 & 1.05 & 1.45 \\
\hline & 216.50 & 12.78 & 0.81 & 1.26 & 1.59 \\
\hline \multirow[t]{2}{*}{ Solvent 5} & 9.10 & 8.45 & 1.09 & 1.79 & 0.60 \\
\hline & 18.20 & 11.09 & 0.82 & 1.90 & 1.34 \\
\hline \multirow{4}{*}{$\begin{array}{c}\text { Hexyl Carbitol } \\
\text { Solvent }\end{array}$} & 36.40 & 13.62 & 0.77 & 1.59 & 1.78 \\
\hline & 68.20 & 16.96 & 0.82 & 2.14 & 2.07 \\
\hline & 136.40 & 25.74 & 0.51 & 143.45 & 5.36 \\
\hline & 204.50 & 31.07 & 0.50 & 165.51 & 5.75 \\
\hline \multirow[t]{2}{*}{ Solvent 6} & 8.90 & 12.12 & 0.62 & 2.10 & 2.05 \\
\hline & 17.70 & 16.16 & 0.44 & 7.05 & 3.76 \\
\hline \multirow{3}{*}{$\begin{array}{c}\text { Ecosoft( TM ) } \\
\text { Solvent PH }\end{array}$} & 66.40 & 18.40 & 0.48 & 8.02 & 4.00 \\
\hline & 132.80 & 22.19 & 0.56 & 8.82 & 4.20 \\
\hline & 200.25 & 30.02 & 0.44 & 233.60 & 6.83 \\
\hline \multirow{5}{*}{$\begin{array}{c}\text { Solvent } 7 \\
\text { Filtered TAFT OXO } \\
\text { Mixture }\end{array}$} & 8.93 & 9.23 & 0.90 & 4.63 & 0.96 \\
\hline & 33.30 & 10.52 & 0.96 & 4.92 & 0.99 \\
\hline & 62.50 & 10.35 & 1.20 & 1.95 & 0.62 \\
\hline & 125.00 & 11.27 & 0.90 & 6.54 & 1.14 \\
\hline & 187.00 & 11.59 & 0.89 & 6.86 & 1.17 \\
\hline
\end{tabular}


Table 4-1 Ultimate froth height and volume constant as a function of frother concentration

(Cont'ed)

\begin{tabular}{|c|c|c|c|c|c|}
\hline Solvent Name & $\begin{array}{l}\text { Concentrati } \\
\text { on ppm }\end{array}$ & $\begin{array}{l}\text { Ultimate } \\
\text { Froth } \\
\text { height, Ho } \\
\mathrm{cm}\end{array}$ & $\begin{array}{c}\text { Volume } \\
\text { Constant, } \\
\mathrm{Ka} \\
\mathrm{Min} / \mathrm{L}\end{array}$ & $\begin{array}{c}\text { Sum of } \\
\text { Least } \\
\text { Squares } \\
\mathrm{cm}^{2}\end{array}$ & $\begin{array}{c}\text { Standard } \\
\text { Deviation } \\
\mathrm{cm}\end{array}$ \\
\hline \multirow[t]{2}{*}{ Solvent 8} & 10.40 & 10.84 & 0.68 & 13.76 & 1.66 \\
\hline & 41.60 & 13.70 & 0.78 & 15.89 & 1.78 \\
\hline \multirow{3}{*}{$\begin{array}{l}\text { Ecosoft ( TM ) } \\
\text { Solvent PB }\end{array}$} & 78.10 & 23.52 & 0.76 & 107.58 & 4.62 \\
\hline & 156.20 & 40.47 & 0.90 & 177.37 & 5.95 \\
\hline & 234.00 & 57.59 & 0.75 & 432.19 & 9.30 \\
\hline \multirow[t]{2}{*}{ Solvent 9} & 10.40 & 9.07 & 0.74 & 8.51 & 1.30 \\
\hline & 41.60 & 9.68 & 0.760 & 8.50 & 1.30 \\
\hline \multirow{3}{*}{$\begin{array}{l}\text { Ecosoft ( TM ) } \\
\text { Solvent PE }\end{array}$} & 78.10 & 10.52 & 0.76 & 7.07 & 1.19 \\
\hline & 156.20 & 19.93 & 0.43 & 1.15 & 4.71 \\
\hline & 234.00 & 22.29 & 0.54 & 106.90 & 4.62 \\
\hline \multirow[t]{2}{*}{ Solvent 10} & 7.10 & 9.07 & 0.74 & 8.51 & 1.30 \\
\hline & 28.40 & 9.68 & 0.76 & 8.50 & 1.30 \\
\hline \multirow{3}{*}{$\begin{array}{c}\text { TEXAS City OXO } \\
\text { Mixture }\end{array}$} & 51.10 & 10.52 & 0.86 & 7.07 & 1.19 \\
\hline & 106.40 & 11.16 & 1.48 & 1.36 & 0.52 \\
\hline & 160.00 & 11.39 & 1.72 & 1.70 & 0.58 \\
\hline \multirow[t]{2}{*}{ Solvent 11} & 9.00 & 5.67 & 0.43 & 1.18 & 1.53 \\
\hline & 36.00 & 6.14 & 0.87 & 1.17 & 1.53 \\
\hline \multirow{3}{*}{$\begin{array}{l}\text { Butyl Carbitol } \\
\text { ( TM ) Solvent }\end{array}$} & 67.50 & 13.33 & 1.23 & 6.68 & 2.99 \\
\hline & 135.00 & 19.39 & 0.85 & 7.13 & 3.78 \\
\hline & 202.50 & 21.59 & 0.70 & 6.64 & 3.64 \\
\hline \multirow[t]{2}{*}{ Solvent 12} & 10.80 & 6.35 & 0.49 & 3.50 & 2.67 \\
\hline & 43.00 & 6.42 & 0.496 & 2.16 & 2.08 \\
\hline \multirow{3}{*}{$\begin{array}{l}\text { Acetone Polymer } \\
\text { (CDTA regulated) }\end{array}$} & 81.00 & 6.94 & 0.54 & 1.56 & 1.76 \\
\hline & 125.00 & 7.73 & 0.58 & 2.46 & 2.22 \\
\hline & 241.90 & 8.56 & 0.69 & 2.56 & 2.26 \\
\hline \multirow[t]{2}{*}{ Solvent 13} & 12.28 & 9.23 & 0.68 & 10.71 & 0.46 \\
\hline & 49.12 & 13.57 & 0.77 & 1.62 & 1.80 \\
\hline \multirow[t]{3}{*}{ Dow froth 250} & 92.10 & 18.46 & 0.62 & 5.02 & 3.17 \\
\hline & 184.20 & 28.20 & 0.57 & 10.96 & 5.45 \\
\hline & 276.20 & 36.32 & 0.47 & 24.02 & 8.06 \\
\hline \multirow{5}{*}{ Dow froth 150} & 13.00 & 10.54 & 057 & 1.89 & 1.94 \\
\hline & 52.00 & 11.33 & 0.77 & 1.11 & 1.49 \\
\hline & 97.50 & 12.04 & 0.93 & 7.27 & 1.21 \\
\hline & 195.00 & 14.47 & 1.12 & 6.13 & 1.11 \\
\hline & 292.50 & 16.76 & 1.01 & 7.85 & 1.25 \\
\hline
\end{tabular}




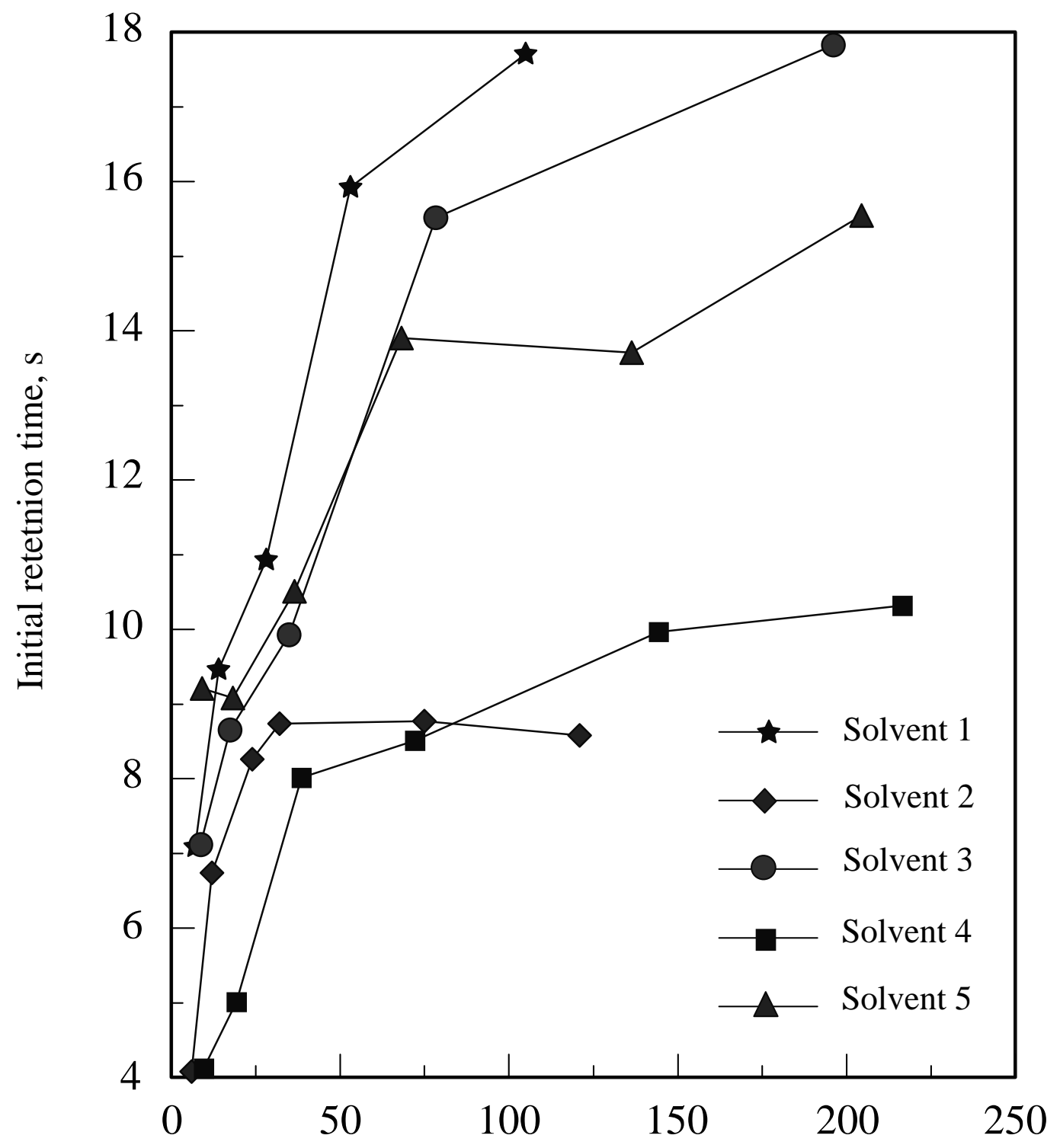

Frother concentration, ppm

Figure 4-6a Initial retention time as a function of solvent concentration 


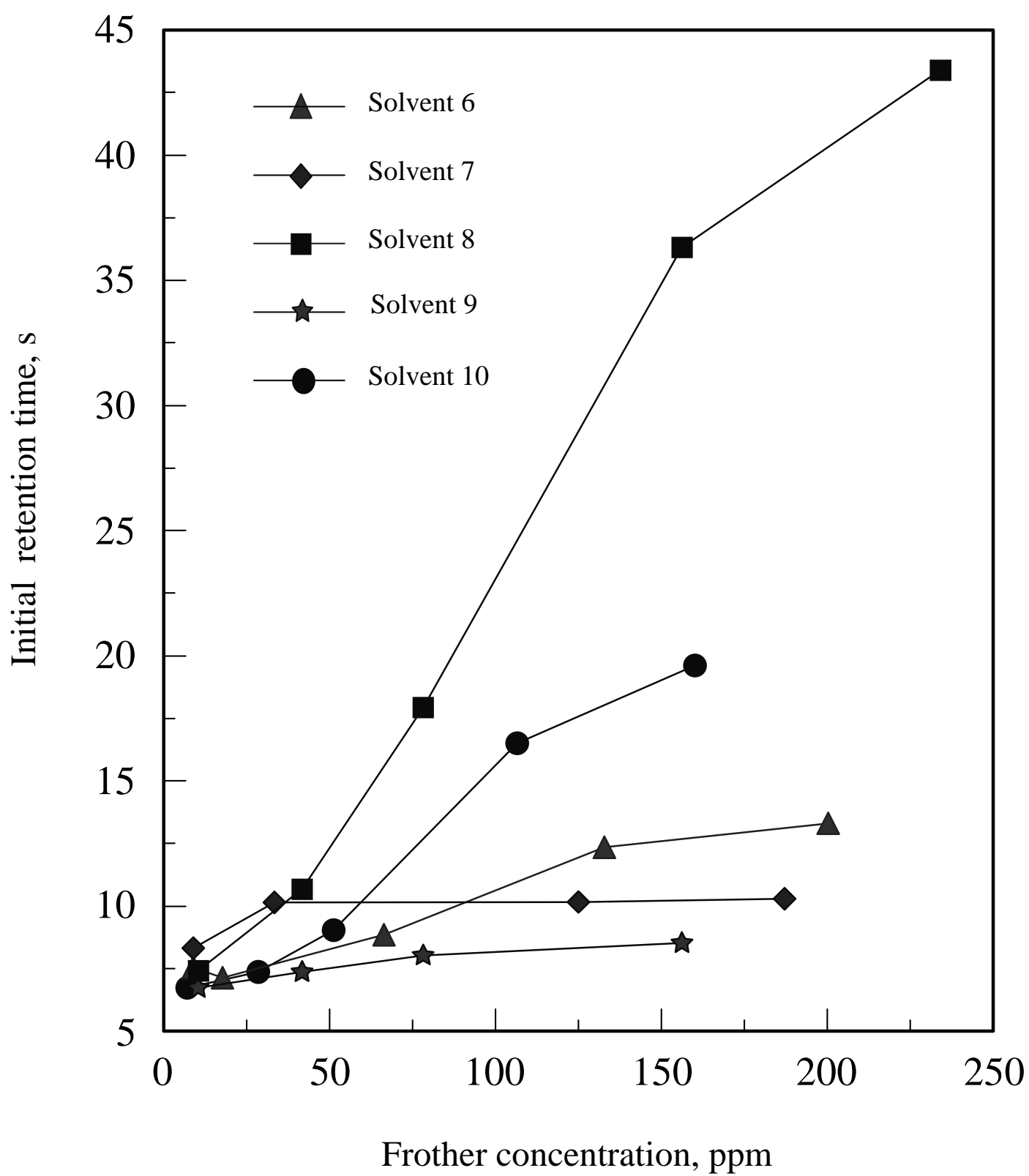

Figure 4-6b Initial retention time as a function of solvent concentration 


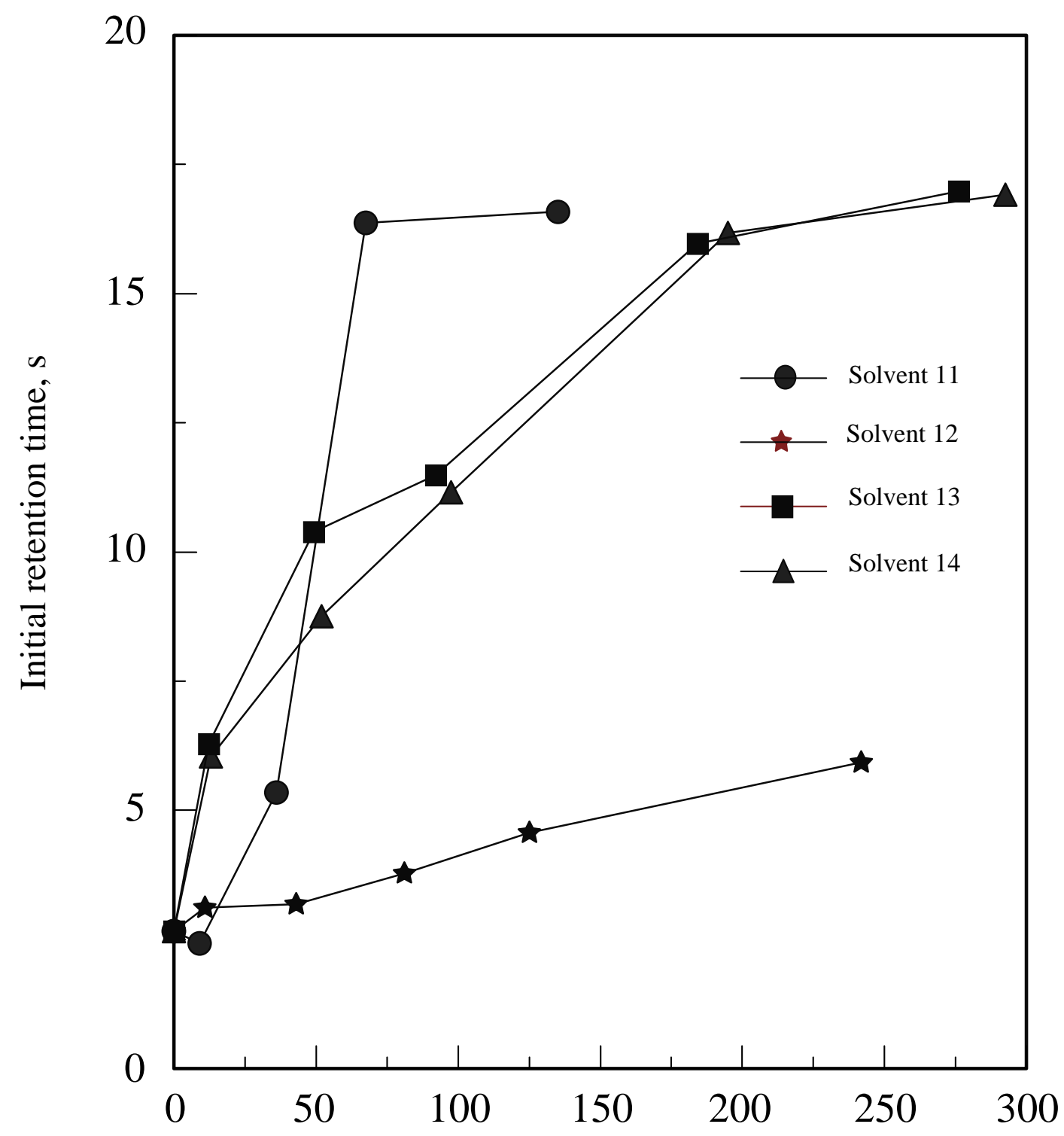

Frother concentration, ppm

Figure 4-6c Initial retention time as a function of solvent concentration 


\subsubsection{Initial Dynamic Froth Index (IDFI)}

To evaluate the frothability of the solvents such as polyglycol ethers, a new parameter is derived. This new parameter is derived from IRT versus solvent concentration curve for $\mathrm{C} \rightarrow 0$. This limiting slope, initial dynamic frothability index (IDFI), is defined as shown below

$$
\mathrm{IDFI}=\left[\frac{\mathrm{d}(\mathrm{IRT})}{\mathrm{dC}}\right]_{\mathrm{C} \rightarrow 0}
$$

IRT can be expressed as a function of solvent concentration, which can be written as

$$
\text { IRT }-2.6615=\operatorname{IRT}_{\infty}\left[1-\exp \left(-\mathrm{K}_{\mathrm{d}} \mathrm{C}\right)\right]
$$

where IRT $\infty$ is the limiting value of IRT for $\mathrm{C} \rightarrow 0$. C is the solvent concentration, and $\mathrm{K}_{\mathrm{d}}$ is a concentration constant. The quantity 2.6615 is the value of retention time, Rt, obtained for distilled water used in the measurements. Figure 4-7 shows the initial retention time as a function of solvent concentration for Solvent 13 (Dow froth 250). The solid line represents the best fits of Equation (4-18) to the experimental data points. To obtain the value of IDFI, Equation (4-18) is substituted into Equation (4-17) and yields

$$
\mathrm{IDFI}=\left(\frac{\partial(\mathrm{IRT})}{\partial \mathrm{C}}\right)_{\mathrm{C} \rightarrow 0}=\mathrm{IRT}_{\infty} \mathrm{K}_{\mathrm{d}}
$$

Thus, from Equations (4-17) and (4-18), the values for the initial dynamic frothability index and ultimate initial retention time can be obtained for solvents studied. The results are given in Table 4-2. The product of this new defined parameter, IDFI, and solvent concentration, $\mathrm{C}$, provide the information of the frothing properties for the solvents studied, under dynamic steady-state conditions. The fine coal flotation requires relatively low frother dosage (50 200 g/ton). When $\mathrm{C} \rightarrow 0$, rewriting the expression $\exp \left(-\mathrm{K}_{\mathrm{d}} \mathrm{C}\right.$ ) into a Taylor series expression gives

$$
\exp \left(-\mathrm{K}_{\mathrm{d}} \mathrm{C}\right)=1-\mathrm{K}_{\mathrm{d}} \mathrm{C}+\frac{1}{2 !}\left(\mathrm{K}_{\mathrm{d}} \mathrm{C}\right)^{2}-\frac{1}{3 !}\left(\mathrm{K}_{\mathrm{d}} \mathrm{C}\right)^{3}+\cdots+\frac{1}{(\mathrm{n}+1) !}\left(-\mathrm{K}_{\mathrm{d}} \mathrm{C}\right)^{\mathrm{n}}
$$

where $\mathrm{n} \rightarrow \infty$

Substituting Equation (4-20) into Equation (4-18) yields

$$
\begin{aligned}
\text { IRT }-2.6615 & =\operatorname{IRT}_{\infty}\left[1-\exp \left(-\mathrm{K}_{\mathrm{d}} \mathrm{C}\right)\right] \\
& =\operatorname{IRT}_{\infty}\left[\mathrm{K}_{\mathrm{d}} \mathrm{C}-\frac{1}{2 !}\left(\mathrm{K}_{\mathrm{d}} \mathrm{C}\right)^{2}+\frac{1}{3 !}\left(\mathrm{K}_{\mathrm{d}} \mathrm{C}\right)^{3}+\cdots-\frac{1}{(\mathrm{n}+1) !}\left(-\mathrm{K}_{\mathrm{d}} \mathrm{C}\right)^{\mathrm{n}}\right]
\end{aligned}
$$

At low frother concentration, the higher order terms can be ignored, and then Equation (4-21) becomes

$$
\text { IRT }-2.6615 \approx \mathrm{IRT}_{\infty} \mathrm{K}_{\mathrm{d}} \mathrm{C}=\mathrm{IDFI} \cdot \mathrm{C}
$$

The product of IDFI and $\mathrm{C}$ represents the initial retention time difference between the solvent in a solution and in the pure water.

From Table 4-2, IDFI for the solvents investigated decreases in the following order: Filtered TAFT OXO Mixture (Solvent 7) > Unfiltered TAFT OXO Mixture (Solvent 1) $\sim$ Hexyl Carbitol Solvent (Solvent 5) > MIBC (Solvent 2) > Butoxytriglycol (Solvent 3) $\sim$ Ecosoft (TM) Solvent PH (Solvent 6) $\sim$ Ecosoft (TM) Solvent PB (Solvent 8) > Butyl 


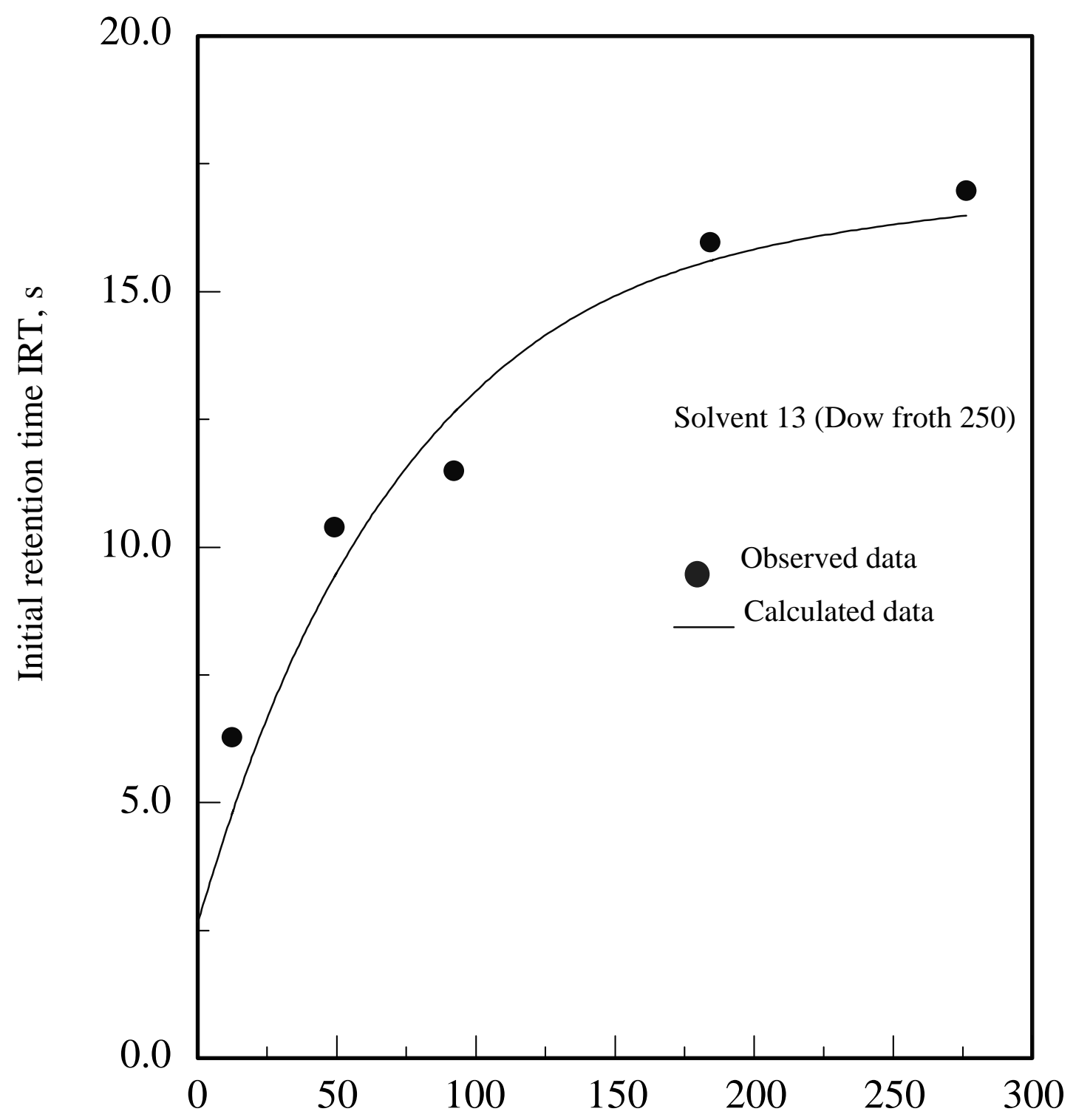

Frother concentration C, ppm

Figure 4-7 Initial retention time as a function of solvent concentration (Dow froth 250, Solvent 13) 
Table 4-2 Initial retention time as a function of frother concentration

\begin{tabular}{|l||r|r|r|r|r||}
\hline Solvent & \multicolumn{1}{|c|}{$\begin{array}{c}\text { IRT }_{\infty} \\
\mathrm{sec}\end{array}$} & $\begin{array}{c}\mathrm{K}_{\mathrm{d}}\left(\times 10^{-2}\right) \\
\mathrm{ppm}^{-1}\end{array}$ & $\begin{array}{c}\text { IDFI } \\
\mathrm{secdm}^{3} \mathrm{~g}^{-1}\end{array}$ & $\begin{array}{c}\text { Least Sum of } \\
\text { Squares } \\
\mathrm{sec}^{2}\end{array}$ & $\begin{array}{c}\text { Standard } \\
\text { Deviation } \\
\text { sec }\end{array}$ \\
\hline \hline 1 & 15.25 & 3.61 & 549.0 & 3.7435 & 1.1171 \\
\hline 2 & 6.27 & 7.45 & 467.1 & 1.0136 & 1.8534 \\
\hline 3 & 15.08 & 2.44 & 367.8 & 4.9703 & 1.2872 \\
\hline 4 & 7.55 & 2.40 & 181.0 & 1.1255 & 1.9514 \\
\hline 5 & 11.98 & 4.50 & 538.6 & 9.8432 & 1.8114 \\
\hline 6 & 9.32 & 3.94 & 367.0 & 1.2427 & 2.0353 \\
\hline 7 & 7.54 & 15.55 & 1166.2 & 0.1590 & 0.8470 \\
\hline 8 & 45.63 & 0.77 & 352.9 & 16.5680 & 4.5076 \\
\hline 9 & 7.06 & 3.53 & 249.2 & 3.3517 & 2.0270 \\
\hline 10 & 21.49 & 0.70 & 150.4 & 6.6870 & 2.7362 \\
\hline 11 & 16.74 & 1.62 & 270.7 & 4.1590 & 2.7659 \\
\hline 12 & 3.57 & 0.67 & 23.9 & 1.8666 & 1.5130 \\
\hline 13 & 14.21 & 1.11 & 158.3 & 7.6669 & 1.6090 \\
\hline 14 & 15.09 & 0.58 & 87.5 & 7.6678 & 3.0660 \\
\hline \hline
\end{tabular}

Carbitol (Solvent 11) Ecosoft (TM) Solvent PE (Solvent 9) > Ethoxytriglycol (Solvent 4) $\sim$ Dow froth 250 (Solvent 13) TEXAS CITY OXO Mixture (Solvent 10) > Dow Froth 150 (Solvent 14) > Aceton Polymer (Solvent 12).

\subsection{Factors Affecting Frothability}

\subsubsection{Molecular Weight Effect}

It has been known that increase in the length of the hydrophobic group of the frothers results in higher frothability. Introduction of branching or unsaturated chains into the hydrophobic group of the frother increases solubility in water and leads to loosely packed froth. The general characteristics normally is attributed to a linear branched alcohol such as MIBC which has faster kinetics, brittle froth and less tenacity.

The dependence of IDFI on the solvent molecular weight is shown in the Table 4-3 and in Figure 4-8 for the solvents having clearly known chemical structures. The results show that, if two solvents belong to the same frother type, and have similar molecular structure, increasing in the molecular weight, especially in hydrophobic groups, will result in a higher IDFI value. Solvent 3 and Solvent 4 are Triethylene glycol ethers, Solvent $3\left(\mathrm{CH}_{3} \mathrm{CH}_{2} \mathrm{CH}_{2} \mathrm{CH}_{2} \mathrm{O}\left(\mathrm{CH}_{2} \mathrm{CH}_{2} \mathrm{O}\right)_{3} \mathrm{H}\right)$, has IDFI of 367.8 , while Solvent 4 $\left(\mathrm{CH}_{3} \mathrm{CH}_{2} \mathrm{O}\left(\mathrm{CH}_{2} \mathrm{CH}_{2} \mathrm{O}\right)_{3} \mathrm{H}\right)$, has IDFI of 81.0. The IDFI value of Solvent 3 is higher than that of Solvent 4, which can be attributed to the additional two $-\mathrm{CH}_{2}$ - groups in Solvent 3. Similarly, Solvent 5 and Solvent 11 are Diethylene glycol ethers. Solvent 5 


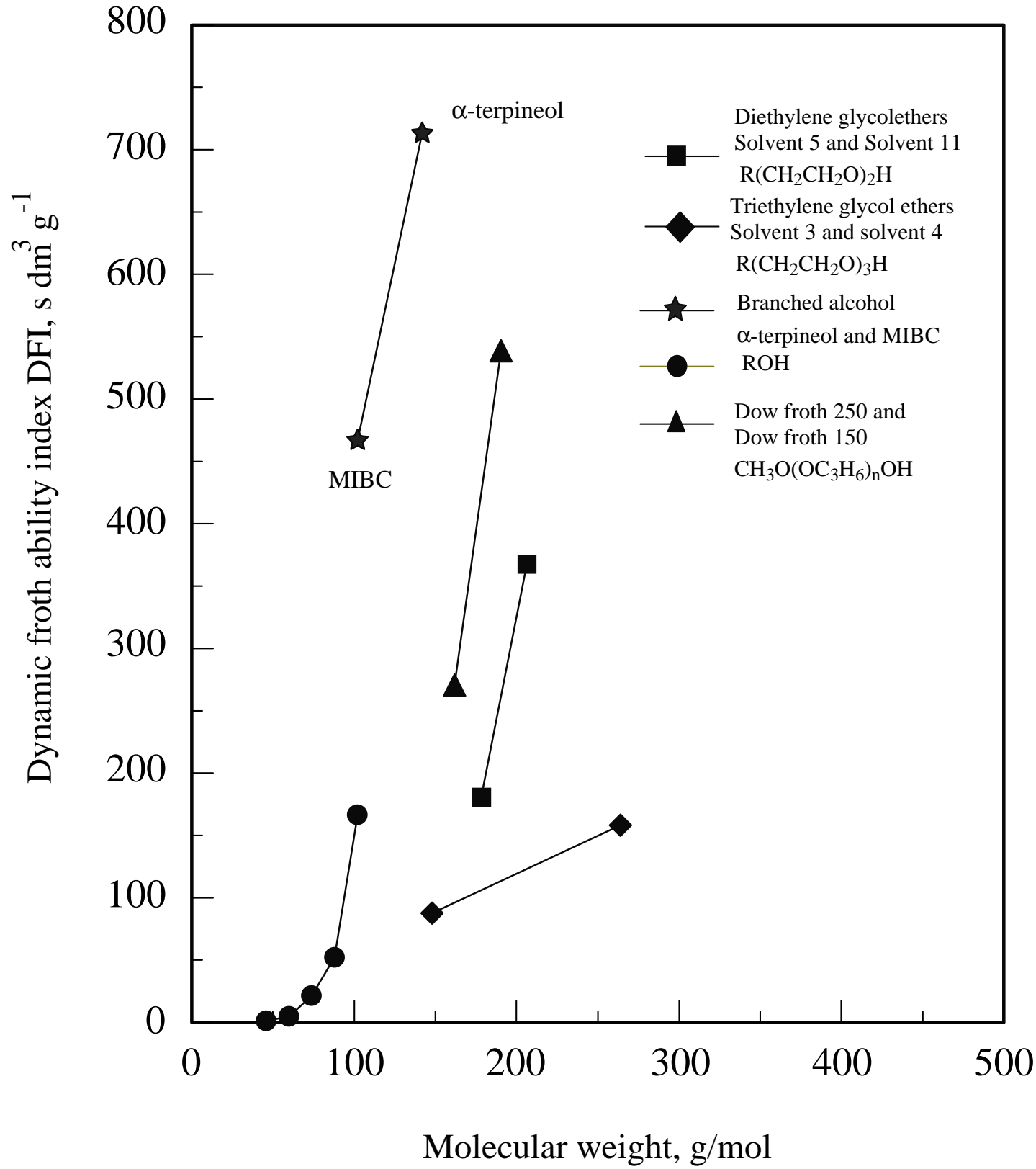

Figure 4-8 Dependence of DFI value on molecular weight 
$\left(\mathrm{CH}_{3} \mathrm{CH}_{2} \mathrm{CH}_{2} \mathrm{CH}_{2} \mathrm{CH}_{2} \mathrm{CH}_{2} \mathrm{O}\left(\mathrm{CH}_{2} \mathrm{CH}_{2} \mathrm{O}\right)_{2} \mathrm{H}\right)$ has IDFI of 538.6, and Solvent11 $\left(\mathrm{CH}_{3} \mathrm{CH}_{2} \mathrm{CH}_{2} \mathrm{CH}_{2} \mathrm{O}\left(\mathrm{CH}_{2} \mathrm{CH}_{2} \mathrm{O}\right)_{2} \mathrm{H}\right)$, has IDFI of 270.7. The difference of IDFI between Solvent 5 and Solvent 11 can be due to one additional $-\mathrm{CH}_{2}$ - group in Solvent 5. Solvent $13\left(\mathrm{CH}_{3} \mathrm{O}\left(\mathrm{CHCH}_{2} \mathrm{CH}_{2} \mathrm{O}\right)_{4} \mathrm{H}\right)$, has IDFI of 158.3, and Solvent 14 $\left(\mathrm{CH}_{3} \mathrm{O}\left(\mathrm{CHCH}_{2} \mathrm{CH}_{2} \mathrm{O}\right)_{2} \mathrm{H}\right)$, has IDFI of 87.5. It is clearly shown that the difference of IDFI between Solvent 13 and Solvent 14 may also be due to a larger group of PO in Solvent 13.

Table 4-3 IDFI values for several test solvents

\begin{tabular}{|c||l|c|c|}
\hline Solvent No. & \multicolumn{1}{|c|}{ Chemical Structure } & Molecular weight & IDFI \\
\hline \hline 2 & $\mathrm{CH}_{3} \mathrm{CHCH}_{3} \mathrm{CH}_{2} \mathrm{COHCH}_{3}$ & 102 & 467.1 \\
\hline 3 & $\mathrm{CH}_{3} \mathrm{CH}_{2} \mathrm{CH}_{2} \mathrm{CH}_{2} \mathrm{O}\left(\mathrm{CH}_{2} \mathrm{CH}_{2} \mathrm{O}\right)_{3} \mathrm{H}$ & 206.3 & 367.8 \\
\hline 4 & $\mathrm{CH}_{3} \mathrm{CH}_{2} \mathrm{O}\left(\mathrm{CH}_{2} \mathrm{CH}_{2} \mathrm{O}\right)_{3} \mathrm{H}$ & 178.0 & 81.0 \\
\hline 5 & $\mathrm{CH}_{3} \mathrm{CH}_{2} \mathrm{CH}_{2} \mathrm{CH}_{2} \mathrm{CH}_{2} \mathrm{CH}_{2} \mathrm{O}\left(\mathrm{CH}_{2} \mathrm{CH}_{2} \mathrm{O}\right)_{2} \mathrm{H}$ & 190.3 & 538.6 \\
\hline 11 & $\mathrm{CH}_{3} \mathrm{CH}_{2} \mathrm{CH}_{2} \mathrm{CH}_{2} \mathrm{O}\left(\mathrm{CH}_{2} \mathrm{CH}_{2} \mathrm{O}\right)_{2} \mathrm{H}$ & 162.3 & 270.7 \\
\hline 13 & $\mathrm{CH}_{3} \mathrm{O}\left(\mathrm{CHCH}_{3} \mathrm{CH}_{2} \mathrm{O}\right)_{4} \mathrm{H}$ & 260 & 158.3 \\
\hline 14 & $\mathrm{CH}_{3} \mathrm{O}\left(\mathrm{CHCH}_{3} \mathrm{CH}_{2} \mathrm{O}\right)_{2} \mathrm{H}$ & 146 & 87.5 \\
\hline
\end{tabular}

Two frothers from different frother types or families may also show a large difference in IDFI values even though they have the same molecular weights. Although Solvent 5 $(\mathrm{MW}=190.3)$ has a lower molecular weight than Solvent $3(\mathrm{MW}=206.3)$, Solvent 5 $($ IDFI $=538.6)$ shows a much higher IDFI than Solvent3 (IDFI = 367.8). The IDFI values of the frothers from the different types or families may be overlapped when their molecular weights are similar.

\subsubsection{Chemical Structure Effect}

For Polyglycol ethers, the hydrophobic groups include butylene oxide (BO) and propylene oxide (PO). The difference of hydrophobic properties for different frother types may also contribute to the difference in their IDFI values. The chemical structures of $\mathrm{BO}$ and $\mathrm{PO}$ are<smiles>CC(C=O)CC(=O)O</smiles><smiles>CC(O)CC(=O)O</smiles>

The hydrophilic groups include ethylene oxide (EO) and hydroxyl $-\mathrm{OH}$,

EO: $-\mathrm{CH}_{2}-\mathrm{CH}_{2}-\mathrm{CH}-\mathrm{O}-$

$\mathrm{OH}:-\mathrm{OH}$

The relative length of hydrophobic and hydrophilic groups in polyglycol ethers can be modified by changing the number of corresponding groups, and hence changing their frothing properties. Increasing the number of hydrophobic groups $\mathrm{PO}$ and $-\mathrm{CH}_{2}$ will 
increase the IDFI of frothers. This can be used to explain the higher IDFI values of Solvents 3, 13 and 5 than that of Solvents 4, 14, and11. Increasing number of hydrophilic groups EO and $-\mathrm{OH}$ will decrease the IDFI value of the frothers. There are more EO groups in the structure of Solvent 6 than that of Solvent 5. Although Solvent 6 has a higher molecular weight than Solvent 5, its IDFI value is low.

Increasing the number of PO group results in an increase in hydrophobicity of a solvent. However, this effect may be weakened by the combination of PO groups with a strong hydrophilic group. IDFI values of Dow Froth with PO groups are linked directly to an $-\mathrm{OH}$ group, its IDFI values are lower than that of other Polyglycol ether type frothers with similar molecular weight (Fig. 4-8). Thus, the IDFI value of a solvent is not only affected by the molecular weight, but also dependent on its chemical structure.

\subsubsection{Hydrophilic-Lipophilic Balance (HLB) Effect}

The value of hydrophilic-lipophilic balance (HLB) was an index or a scale to measure the hydrophilic-lipophilic balance of a solvent (Laskowski, 1993). The HLB value of a solvent with a known chemical structure can be calculated from the empirical values assigned to the groups. These values are listed in Table 4-4. The formula used to calculate HLB of solvents is given as:

$\mathrm{HLB}=($ hydrophilic group numbers $)+($ lipophilic group numbers $)+7$

Table 4-4 Hydrophilic-lipophilic balance (HLB) group numbers for solvents

\begin{tabular}{||c||l|l|c||}
\hline \multicolumn{1}{|c|}{ Group } & Group number & Group & Group number \\
\hline \hline Hydrophilic & & Lipophilic & \\
\hline \hline $\mathrm{OH}($ free $)$ & 1.9 & $-\mathrm{CH}_{2-}$ & -0.475 \\
\hline$-\mathrm{O}-$ & 1.3 & $\mathrm{CH}_{3-}$ & -0.475 \\
\hline$-\left(\mathrm{CH}_{2} \mathrm{CH}_{2} \mathrm{O}\right)-$ & 0.33 & derived & -0.15 \\
\hline
\end{tabular}

The HLB values of the solvents are given in Table 4-5, including the solvents having clearly defined chemical structures. Lower HLB value of a solvent means stronger hydrophilic characteristics of the solvent and less solubility in water.

Table 4-5 Hydrophilic-lipophilic balance (HLB) for Solvents

\begin{tabular}{|c||l|c|}
\hline Solvent No. & \multicolumn{1}{|c|}{ Chemical Structure } & HLB \\
\hline \hline 2 & $\mathrm{CH}_{3} \mathrm{CHCH}_{3} \mathrm{CH}_{2} \mathrm{COHCH}_{3}$ & 6.10 \\
\hline 3 & $\mathrm{CH}_{3} \mathrm{CH}_{2} \mathrm{CH}_{2} \mathrm{CH}_{2} \mathrm{O}\left(\mathrm{CH}_{2} \mathrm{CH}_{2} \mathrm{O}\right)_{3} \mathrm{H}$ & 7.99 \\
\hline 4 & $\mathrm{CH}_{3} \mathrm{CH}_{2} \mathrm{O}\left(\mathrm{CH}_{2} \mathrm{CH}_{2} \mathrm{O}\right)_{3} \mathrm{H}$ & 8.94 \\
\hline 5 & $\mathrm{CH}_{3} \mathrm{CH}_{2} \mathrm{CH}_{2} \mathrm{CH}_{2} \mathrm{CH}_{2} \mathrm{CH}_{2} \mathrm{O}\left(\mathrm{CH}_{2} \mathrm{CH}_{2} \mathrm{O}\right)_{2} \mathrm{H}$ & 6.71 \\
\hline 11 & $\mathrm{CH}_{3} \mathrm{CH}_{2} \mathrm{CH}_{2} \mathrm{CH}_{2} \mathrm{O}\left(\mathrm{CH}_{2} \mathrm{CH}_{2} \mathrm{O}\right)_{2} \mathrm{H}$ & 7.66 \\
\hline 13 & $\mathrm{CH}_{3} \mathrm{O}\left(\mathrm{CHCH}_{3} \mathrm{CH}_{2} \mathrm{O}\right)_{4} \mathrm{H}$ & 7.83 \\
\hline 14 & $\mathrm{CH}_{3} \mathrm{O}\left(\mathrm{CHCH}_{3} \mathrm{CH}_{2} \mathrm{O}\right)_{2} \mathrm{H}$ & 8.13 \\
\hline
\end{tabular}


HLB values for the frothers used in mineral flotation generally falls between 6 to 11 and for most good frother the HLB values were close to 6 (Laskowski, 1993). The solvent with larger molecular weight will also generate a more persistent froth and much higher surface viscosity. In actual froth flotation processes, the frother with higher molecular weight provides higher recovery at lower selectivity. Some of the solvents provided for this study are the mixture of solvents, or unknown chemical structures. For those solvents having unknown chemical structures, no correlation of HLB, their IDFI and coalescence constants $\mathrm{K}_{\mathrm{c}}$, was performed in this study.

The dependence of HLB value on molecular weight is shown in Figure 4-9. A lower HLB value means the stronger ability for a solvent to lower the surface tension at gas/water interface, and hence 1) results in better hydration of the bubbles, 2) reduces the rate of bubbles coalescence, and 3) leads to appearance of finer bubbles in the present of frother. The effects shown above can lead to a higher retention time for the froth and hence a higher IDFI value.

HLB value alone is not sufficient to characterize the solvent with different molecular weight and area occupied by the molecules. Thus, HLB value has its limitation in comparing and selecting frothers. For example, some frother with different molecular weight may have similar HLB values. The frother with heavier molecular weight always has larger surface viscosity and more persistent froth. In Figure 4-9, for polyglycol ether type frothers, there is no significant difference in their HLB values over a wide range of molecular weight. Solvent 3, Solvent 13 (Dow froth 250), and Solvent 14 all have the HLB value of about 8.0. In fact, they show great difference in their frothing properties.

HLB value can not describe well the chemical structure effect of froth molecular. There is no formula to calculate HLB values of some frothers with aromatic hydrocarbons, containing one or more side chains, aromatic rings, or unsaturated bonds. Some branched alcohols are known to be less surface active than the corresponding straight chain alcohols. Long EO groups are coiled in aqueous phase and form a bulky froth. All these effects, at present, can not be properly accounted from HLB values.

The correlation of IDFI and HLB is plotted in Figure 4-10. For all types of solvents, IDFI value decreases with increasing of HLB values. With the same HLB values, an aliphatic alcohol type frother tends to show a lower IDFI value, while aliphatic alcohol has a lower IDFI value than corresponding branched alcohol. For a triethylene glycol ether type solvent to reach the same HLB number as polypropylene glycol ether type solvent (Dow Froth), it is necessary to add more hydrophobic group, $-\mathrm{CH}_{2^{-}}$, to its chemical structure chain. The long hydrophobic chain can promote densely packed froth in the gas/water interface, and can result in a higher IDFI value. Introducing more hydrophilic EO groups in its chemical structure chain will not only increase the HLB number but also cause chains to be coiled and not fully extended in aqueous phase. This results in the formation of a loosely packed froth with a lower IDFI value.

The branched alcohols can form a loosely packed froth and always show faster frothing kinetics than corresponding linear aliphatic alcohol. For example, hexyl alcohol has a molecular weight of 102 and HLB of 6.0, and MIBC has the same molecular weight and HLB of 6.1. Although hexyl alcohol has a higher limiting initial retention time value 


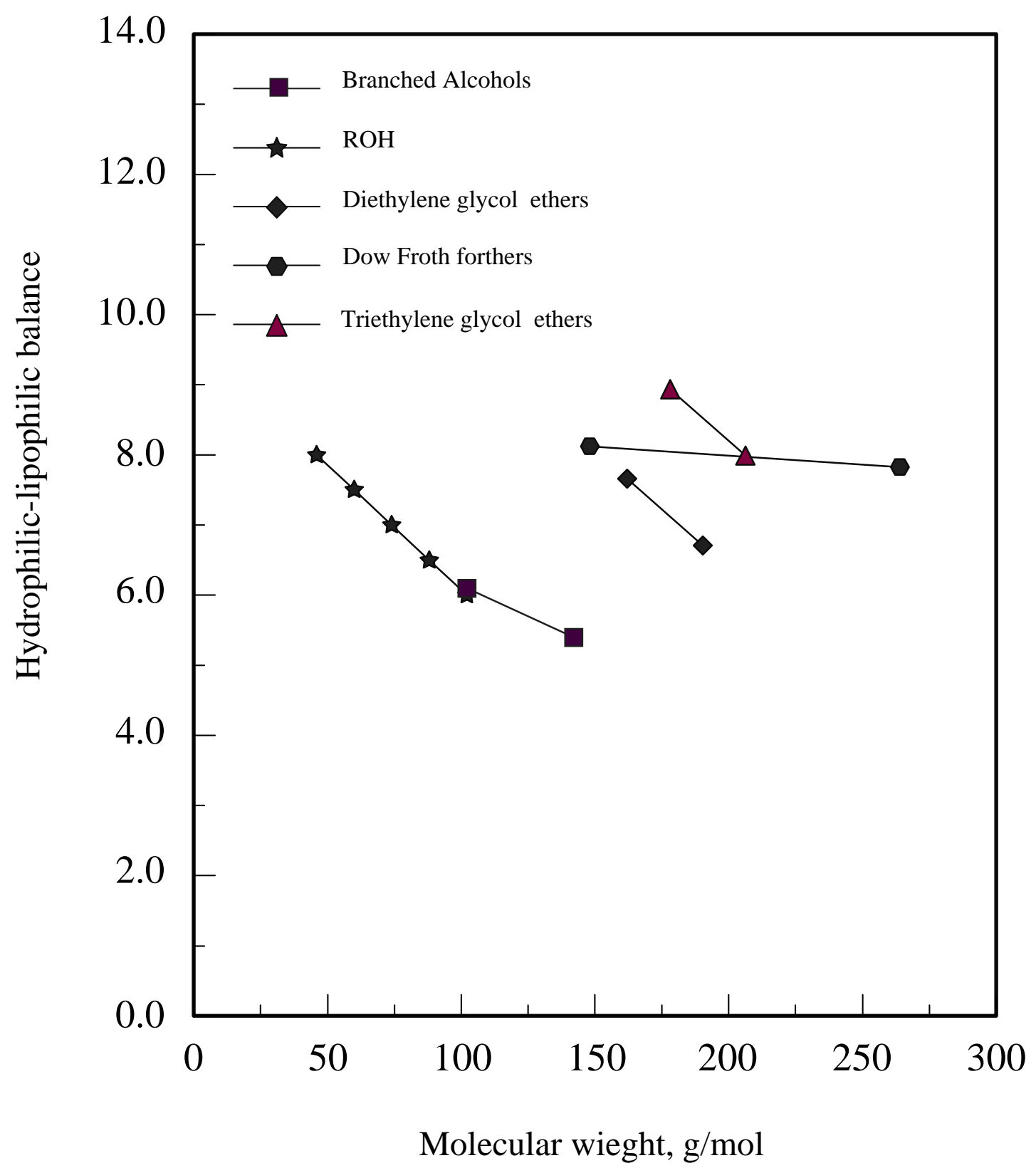

Figure 4-9 Correleration between hydrophilic-lipophilic balance (HLB) and molecular weight 


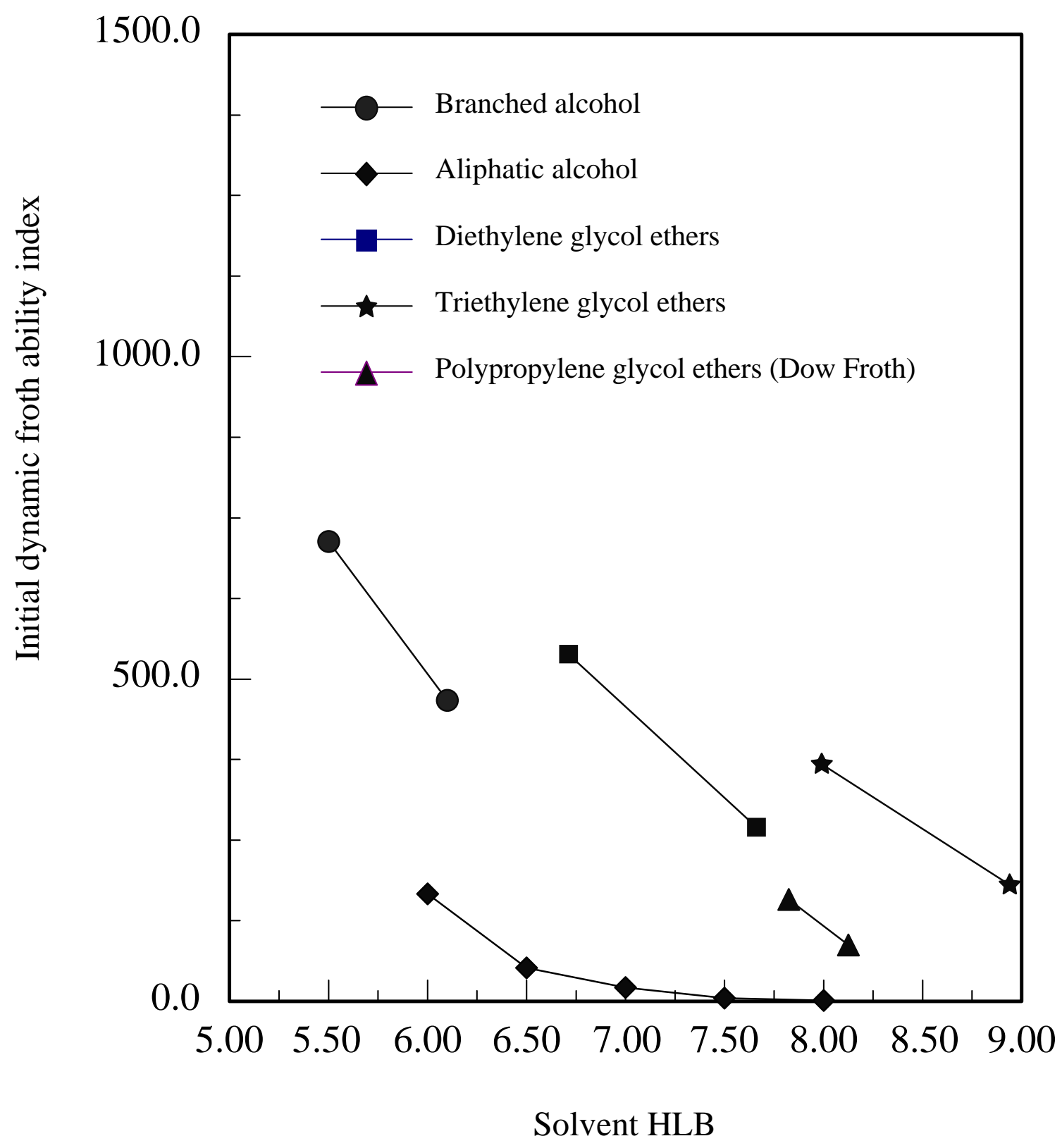

Figure 4-10 Correleration between initial dynamic froth ability index( IDFI) and hydrophilic-lipophilic balance HLB values 
$\left(\mathrm{IRT}_{\infty}=38.9 \mathrm{~s}\right)$ than that of MIBC $\left(\mathrm{IRT}_{\infty}=7.45 \mathrm{~s}\right)$ (Malysa, 1987), hexyl alcohol show a lower concentration constant $\mathrm{K}_{\mathrm{d}}$ value $\left(4.29 \mathrm{dm}^{3} \mathrm{~g}^{-1}\right)$ than $\mathrm{MIBC}\left(\mathrm{K}_{\mathrm{d}}=74.50 \mathrm{dm}^{3} \mathrm{~g}^{-1}\right)$. Thus, a higher $K_{d}$ can result in a higher IDFI value, which is the product of IRT $T_{\infty}$ and $K_{d}$.

\subsection{Coal Flotation and IDFI}

\subsubsection{Coal Floatability}

Through the non-linear regression of Equation (3-3) by the program list in Appendix $\mathrm{C}$, the parameters of fine coal flotation can be estimated. These parameters are ultimate combustible recovery and rate constant. Each solvent will produce a froth with different retention time, which will finally affect the result of fine coal flotation. The frothability of solvent depends on its IDFI value. Although different solvents show different frothability and thus different IDFI values, same $\operatorname{IDFI}^{*} \mathrm{C}$ value can be achieved by adjusting the solvent dosages. The product of IDFI and $\mathrm{C}$ represents the initial retention time difference of the solvent in a solution and that in the pure water.

The relationship between ultimate combustible recovery and coal flotation rate constant versus IDFI*C value for Solvent 2 (MIBC) and Solvent 13 (Dow froth 250) are presented in Figure 4-11. It can be seen that the ultimate combustible recovery and flotation rate constant are the same for a given IDFI*C value, disregarding the different solvent types. As shown in Figure 4-12a and 4-12b, under different collector dosage levels, similar effects of IFDI*C on coal floatability were also observed. In Figure 4-12a, the collector (kerosene) dosage was $0.5 \mathrm{lbs} / \mathrm{ton}$ and the solvent dosage $(0.0015 \mathrm{~mL} / \mathrm{L})$ was the same for all tested solvents. The performance of the fine coal flotation was the same, provided the amount of the solvents were applied to produce the same initial retention time (IDFI*C) value. The results also show that, increasing $\mathrm{IDFI}^{*} \mathrm{C}$, the ultimate combustible recovery decreases gradually, while the rate constant reaches its maximum value of $6.1 \mathrm{~s}^{-1}$ at IDFI*C of 3 seconds and decreases further. The coal floatability using $1.6 \mathrm{lbs} /$ ton kerosene is shown in $4-12 \mathrm{~b}$. When the collector was increased from 0.5 to 1.6 $\mathrm{lbs} / \mathrm{ton}$, the similar phenomena were observed. However, the maximum value of rate constant is $5.5 \mathrm{~s}^{-1}$ at the IDFI* $\mathrm{C}$ of 6 seconds.

\subsubsection{Coal Yield}

The relationship between the clean coal yields and the value of IDFI*C for the different solvents at various collector dosages is shown in Figure 4-13a and 4-13b. In Figure 4-13a, at collector consumption level of $1.5 \mathrm{lbs} / \mathrm{ton}$, the yield has a maximum $\mathrm{IDFI}^{*} \mathrm{C}$ value of 3 at different flotation time. If collector consumption dosage is increased

The higher $\mathrm{IDFI}^{* \mathrm{C}}$ value means a stronger frothing ability and capability of producing smaller bubbles. Smaller bubbles will result in a higher probability of adhesion of fine particles. A further decrease in bubble size, however, causes a decrease in probability of adhesion, hence a lower solids recovery because of decreased sliding time 


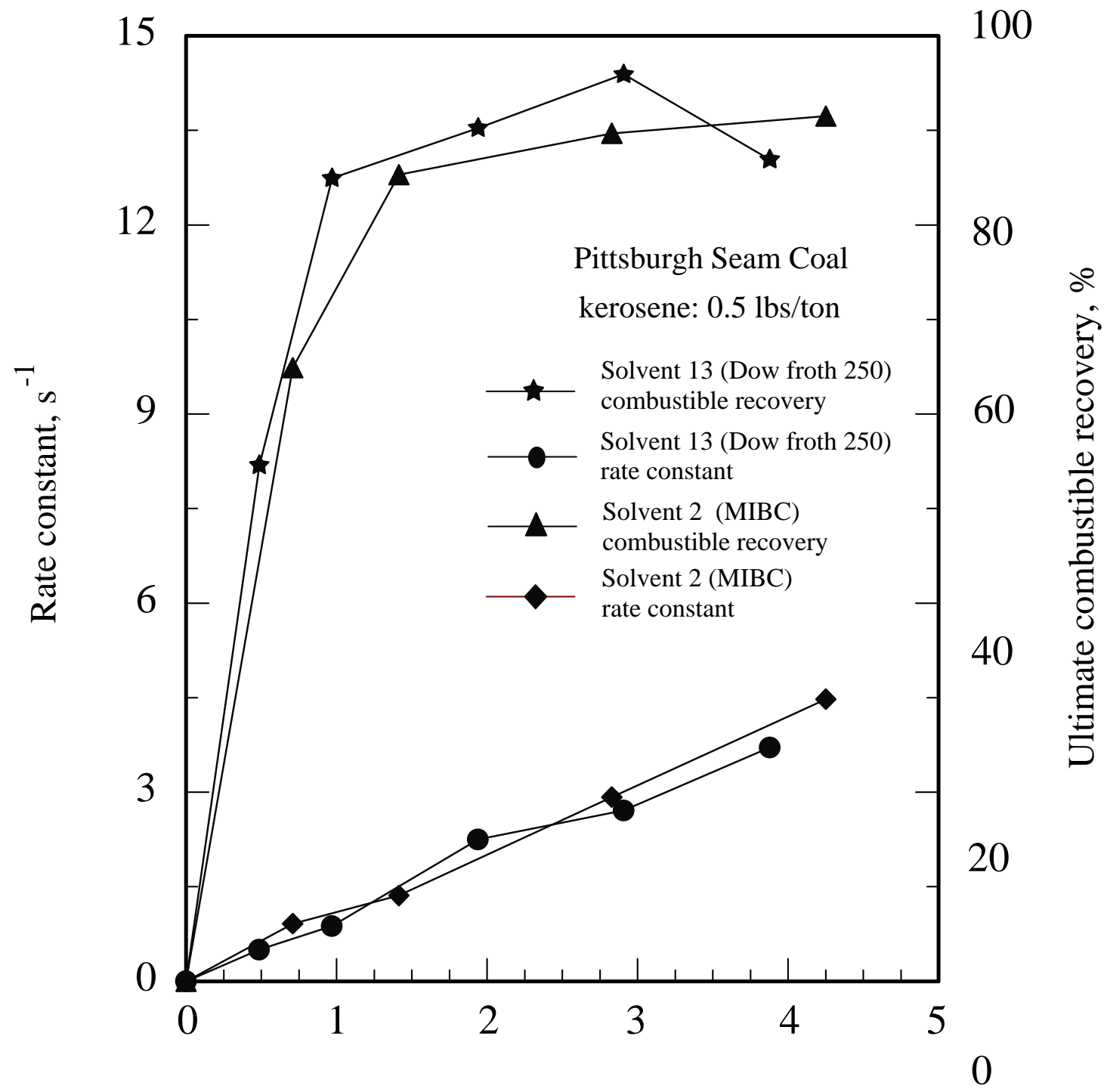

$\mathrm{IDFI}^{*} \mathrm{C}, \mathrm{s}$

Figure 4-11 Ultimate combustible coal recovery and rate constant as a function of IDFI*C 


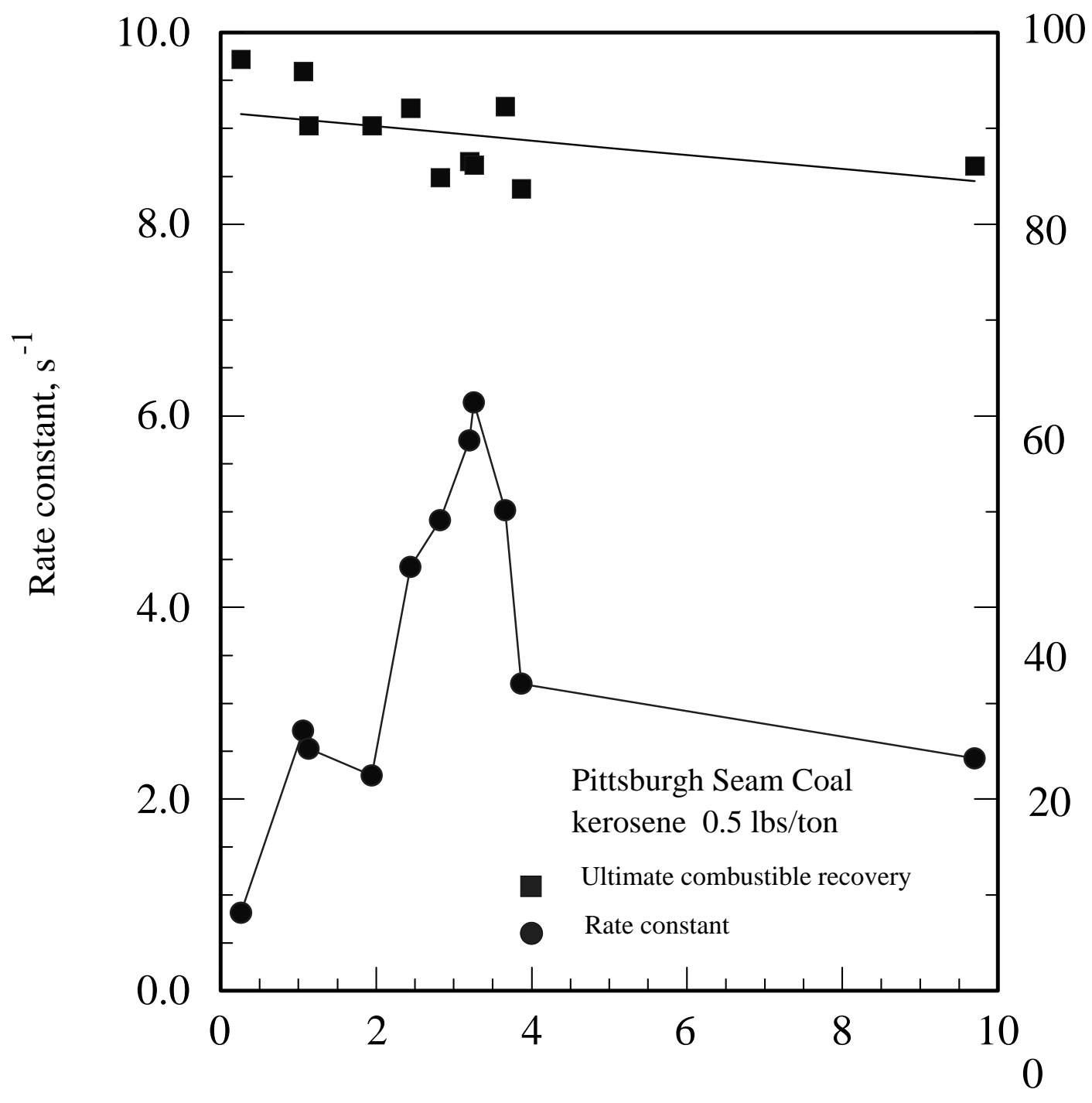

IDFI*C, s

Figure 4-12a Ultimate combustible coal recovery and kinetic rate constant as a function of IDFI* ${ }^{*}$ with low kerosene addition 


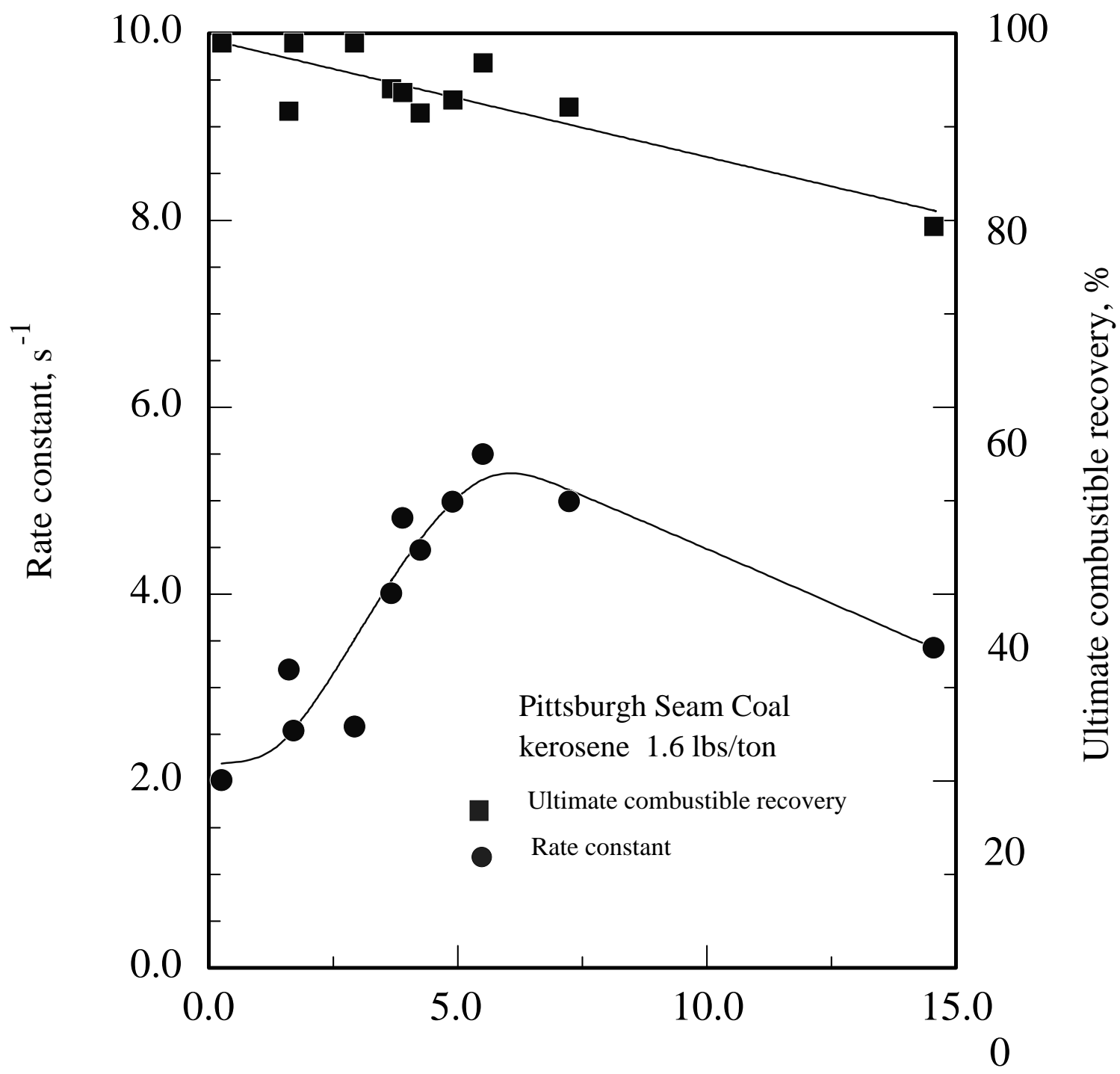

$\mathrm{IDFI}^{*} \mathrm{C}, \mathrm{s}$

Figure 4-12b Ultimate combustiblel coal recovery and rate constant as a function of $\mathrm{IDFI}^{*} \mathrm{C}$ with high kerosene addition 


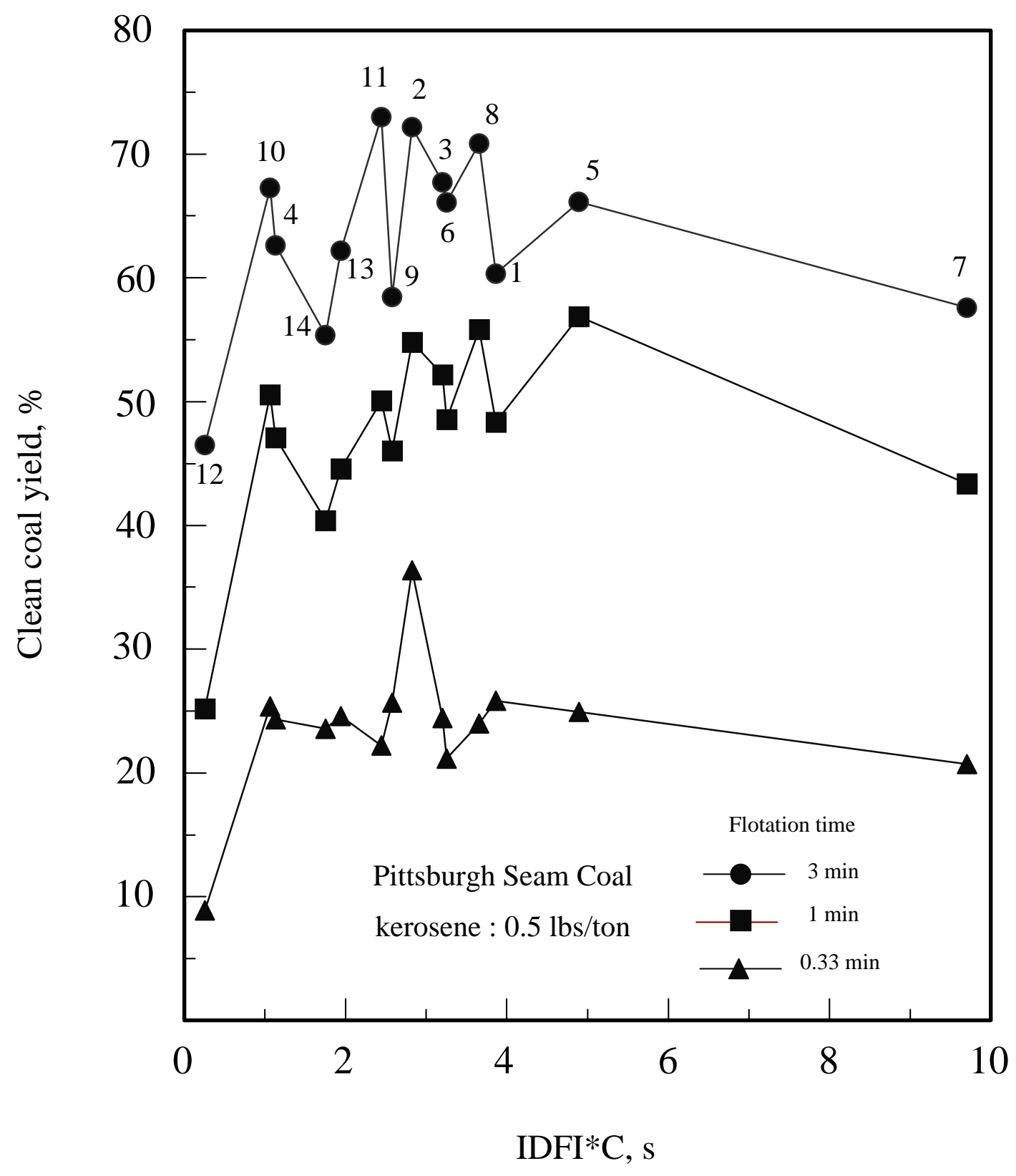

Figure 4-13a Clean coal yield as a function of IDFI ${ }^{*} \mathrm{C}$ with low kerosene addition 


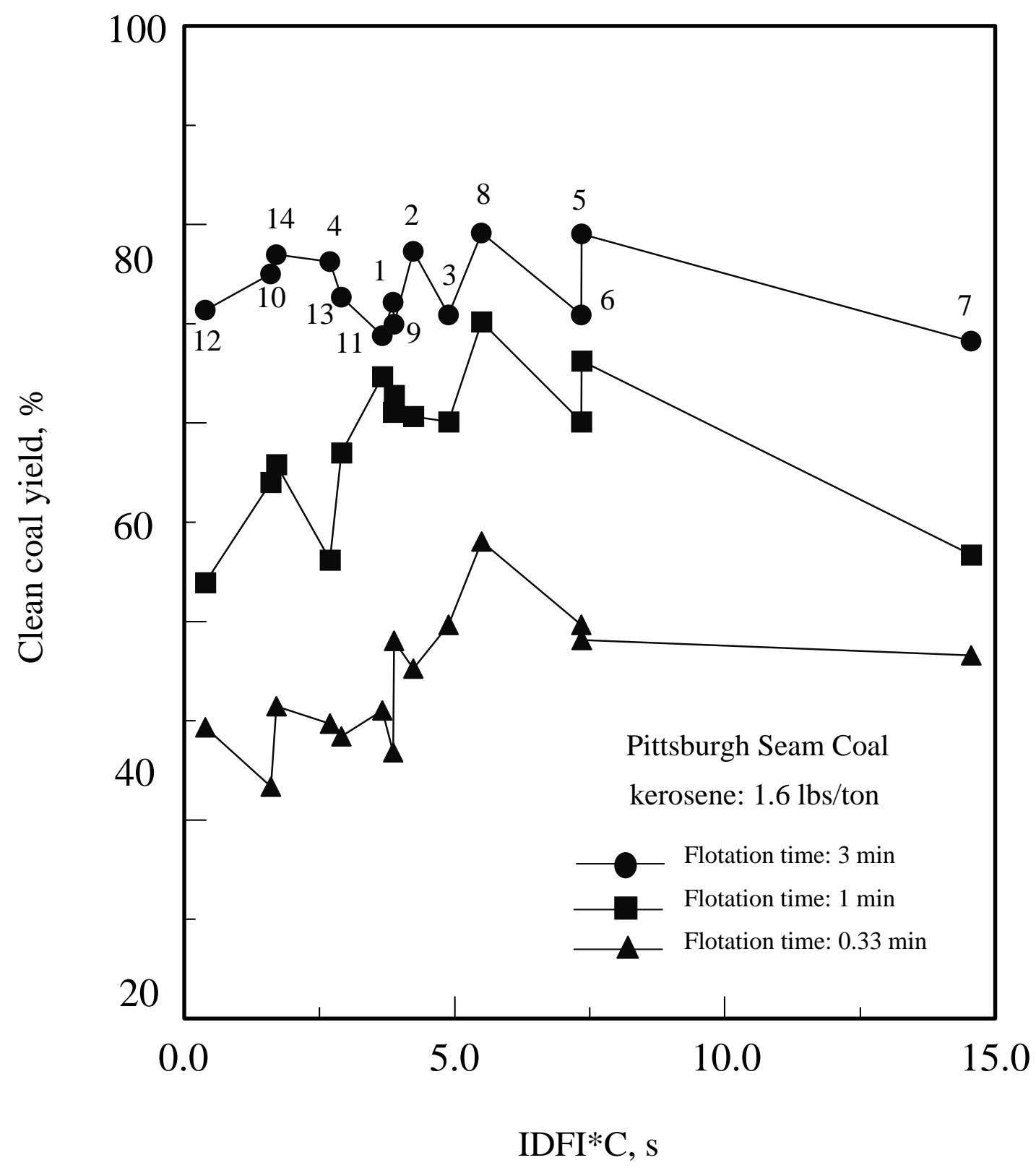

Figure 4-13b Clean coal yield of coal as afunction of IDFI*C with high kerosene addition 
of fine particle. Thus, a too low or too high $\mathrm{IDFI}^{*} \mathrm{C}$ value might result in a low fine particle recovery (Yoon , 1989).

\subsubsection{Flotation Efficiency and Selectivity}

To evaluate the performance of flotation, the following indices are used. Selectivity index is defined as following:

$$
\mathrm{SI}=\mathrm{Y}_{\mathrm{c}} \frac{\mathrm{A}_{\mathrm{t}}}{\mathrm{A}_{\mathrm{c}}}
$$

where, $Y_{c}$ is the yield of clean coal, $A_{t}$ is ash contents of tailings, and $A_{c}$ is ash contents of clean coal.

Separation efficiency is defined as the difference between combustible recovery and ash recovery.

$$
E_{s p}=Y_{c}\left[\frac{100-A_{c}}{100-A_{f}}-\frac{A_{c}}{A_{f}}\right]
$$

Where, $Y_{c}$ is clean coal yield, $A_{f}$ is the ash contents of flotation feed.

Dependence of Selectivity Index, SI and Efficiency Index, EI on IDFI*C values are shown in Figures 4-14a and 4-14b under different collector dosages. Both efficiency and selectivity increase with $\mathrm{IDFI}^{*} \mathrm{C}$ values until a maximum $\mathrm{IDFI}^{*} \mathrm{C}$ value is reached. Further increase of $\mathrm{IDFI}^{*} \mathrm{C}$ value results in decreased separation efficiency and selectivity. SI has its maximum value at the point of IDFI*C, where EI has its maximum value. The increase in collector dosage decreases the value of SI at same point of $\mathrm{IDFI}^{*} \mathrm{C}$. Comparing Figures $4-12 \mathrm{a}$ and $4-14 \mathrm{a}$ and also Figures $4-12 \mathrm{~b}$ and $4-14 \mathrm{~b}$, it is evident that $\mathrm{E}_{\mathrm{sp}}$, $\mathrm{SI}$ and the rate constant have their maximum values at the same IDFI*C and collector dosage.

\subsubsection{Particle Size Effect}

To determine the particle size effect, the clean coal products obtained at various flotation time were sieved for size distribution and ash content determination. The effect of $\mathrm{IDFI}^{*} \mathrm{C}$ value on the flotation of each particle size fraction is shown in Figures 4-15 and 4-16. It can be easily gathered that, as IDFI*C value increases, the combustible recovery also increases and reaches its maximum at an IDFI*C value of 2-4 seconds. Further increasing IDFI*C value will lower the recovery and gradually levels off curves. The combustible recovery and ash recovery in clean coal product have the highest values with the $-210 \mu \mathrm{m}+105 \mu \mathrm{m}$ (US Sieve -No.70+No.140) size fraction.

The frothability of different solvent types has less impact on combustible recovery for minus $45 \mu \mathrm{m}$ (US Sieve No.325) size fraction. On the other hand, the selectivity is much better for plus $210 \mu \mathrm{m}$ (US Sieve No. 60) size fraction. The highly selective nature in the coarse size particle range can be attributed to reduction in the entrainment by the ultrafine particles carrying over to the product with the froth. 


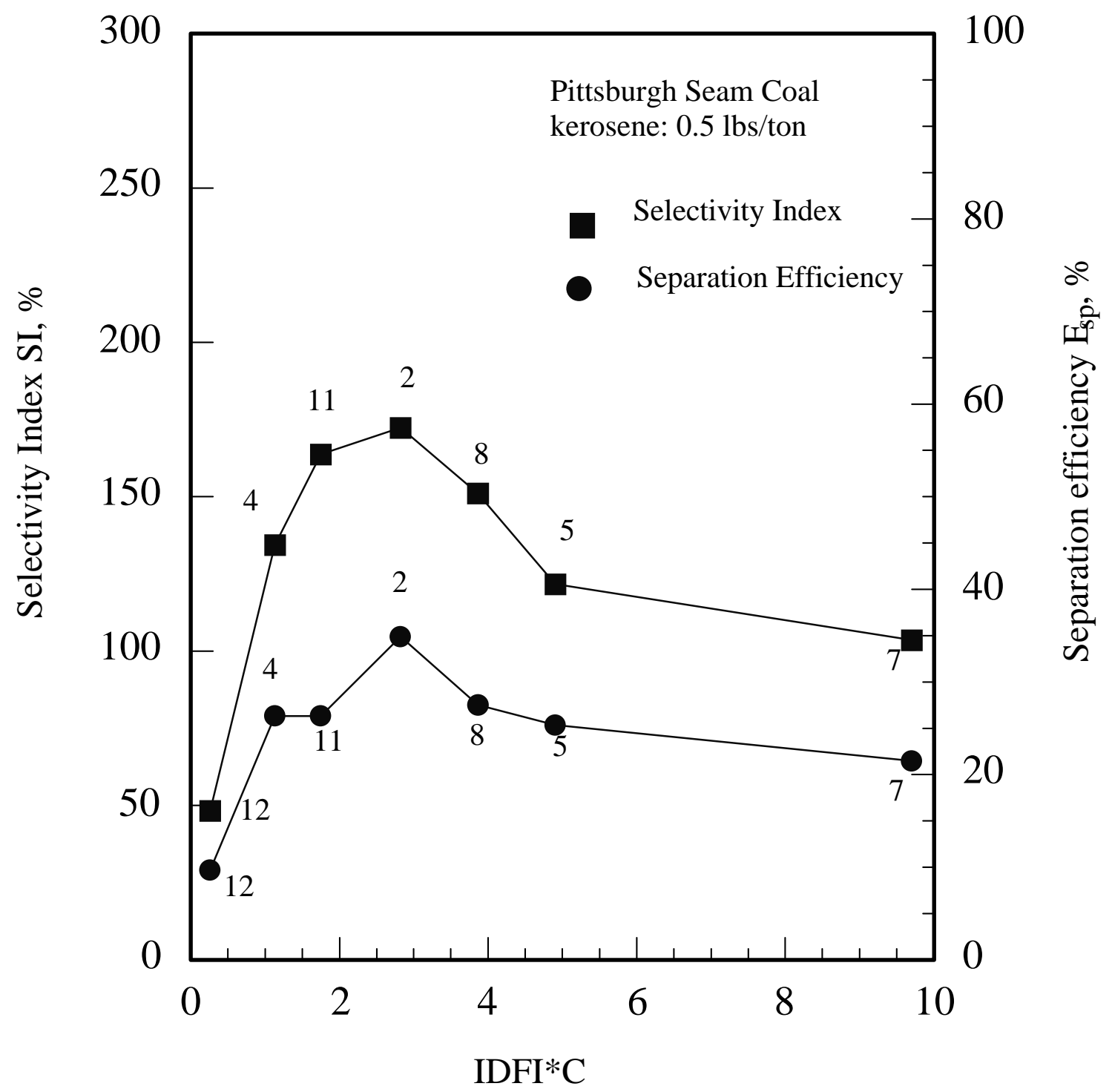

Figure 4-14a Selectivity Index and Separation Efficiency as a function of $\mathrm{IDFI}^{*} \mathrm{C}$ at low kerosene addition 


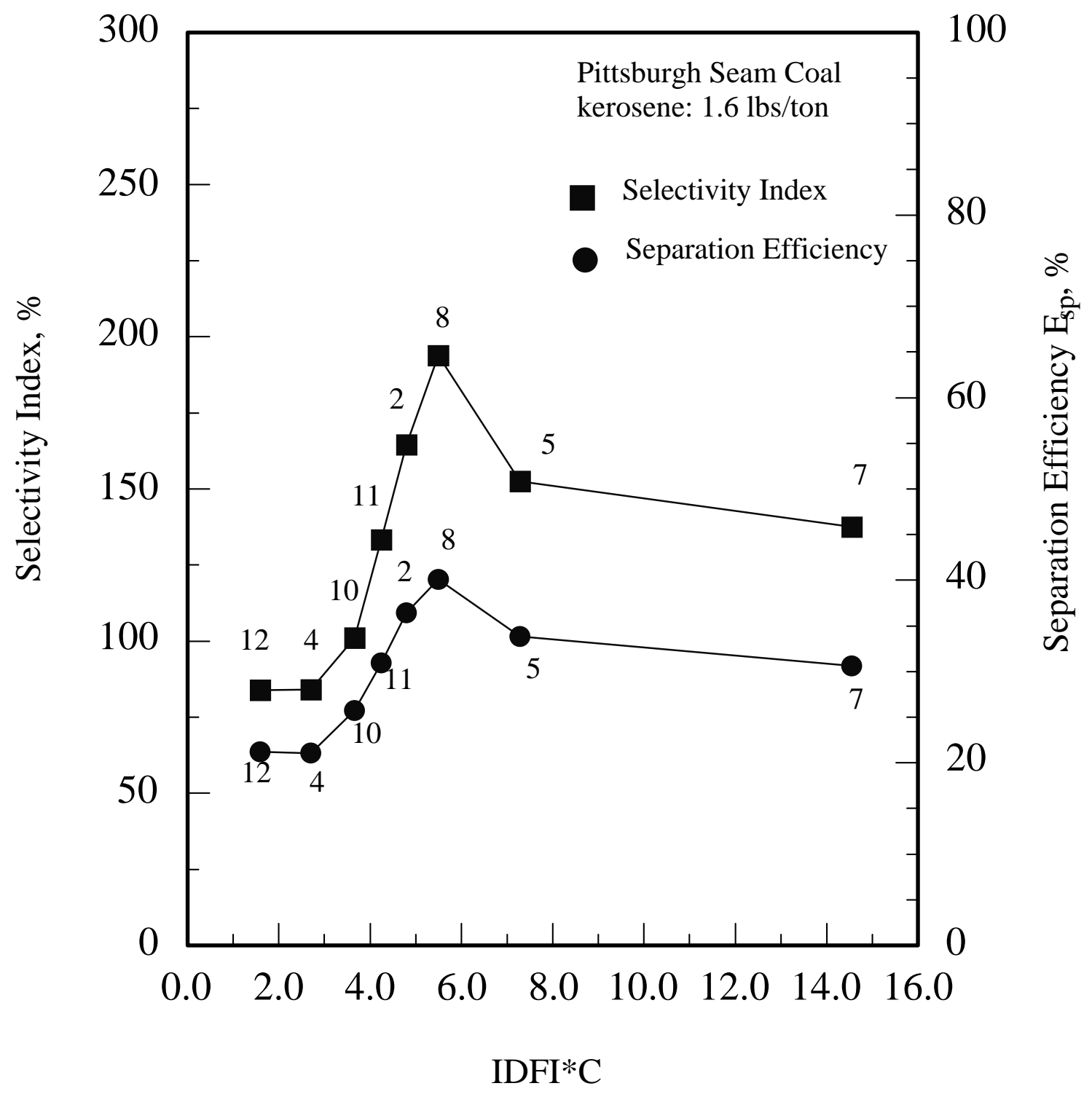

Figure 4-14b Selectivity Index and Separation Efficiency as a function of IDFI* $\mathrm{C}$ at high kerosene addition 


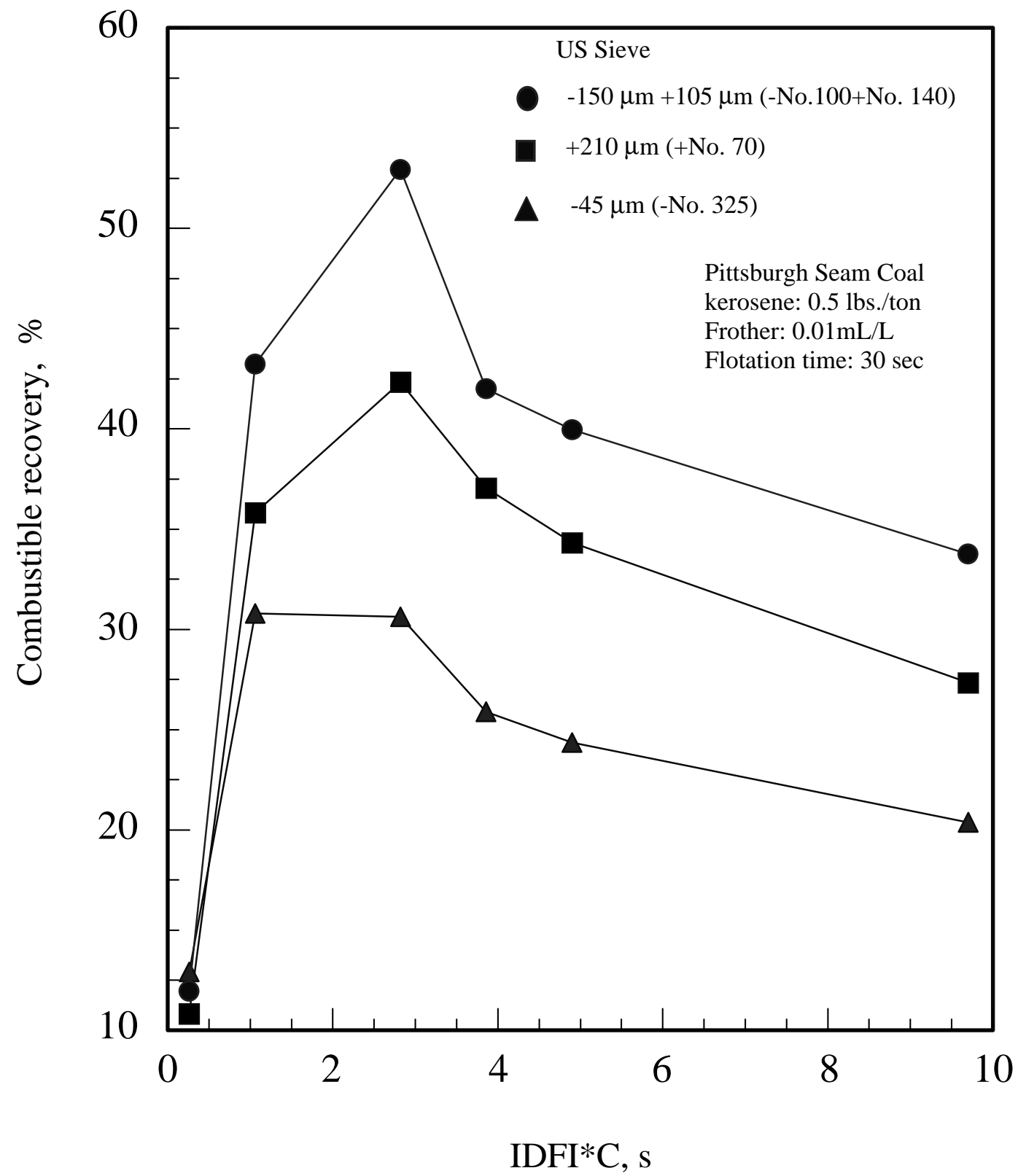

Figure 4-15 Combustible recovery as a function of IDFI*C for different particle size fractions with low kerosene addition 


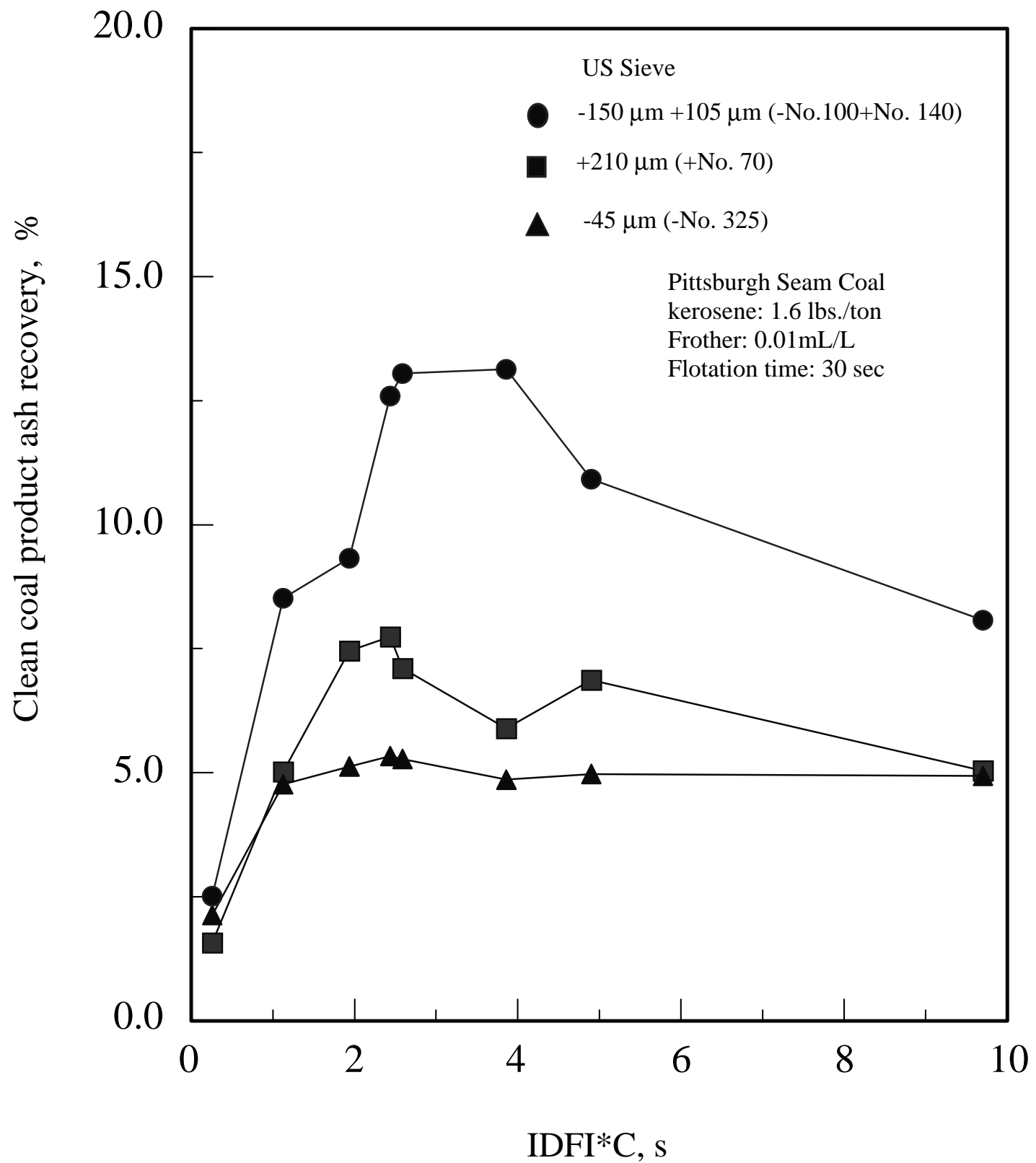

Figure 4-16 Clean coal product ash recovery as a function of $\mathrm{IDFI}^{*} \mathrm{C}$ for different particle size fractions with high kerosene addition 
An overall increase in the flotation rate of the $-210 \mu \mathrm{m}+105 \mu \mathrm{m}$ (US Sieve No.70+No.140) size fraction is due to the strong attachment between air bubbles and coal particles. The ultra-fine particle has lower probability to collide with bubbles due to its small momentum. On the other hand, the coarse particle is relatively easy to detached from bubbles due to its over large momentum.

\subsection{Evaluation of Frother Based on IDFI Values}

The normalized frothability index, NFI, is defined as the ratio of frothability index FI to that of a standard frother, MIBC. Normalized bubble coalescence rate constant, $\mathrm{NK}_{\mathrm{c}}$, is defined as the ratio of the bubble collapse rate constant to that of a standard frother, MIBC.

$$
\begin{aligned}
& \mathrm{NFI}=\frac{\mathrm{FI}_{\text {test }}}{\mathrm{FI}_{\text {ref }}} \\
& \mathrm{NK}_{\mathrm{C}}=\frac{\mathrm{K}_{\mathrm{C}_{\text {test }}}}{\mathrm{K}_{\mathrm{C}_{\text {ref }}}}
\end{aligned}
$$

where, $\mathrm{FI}_{\text {test }}$ and $\mathrm{FI}_{\text {ref }}$ are the frothability index of a test solvent and that of a reference frother respectively. $\mathrm{K}_{\text {Ctest }}$ and $\mathrm{K}_{\mathrm{Cref}}$ are the bubble coalescence rate constant of a test solvent and that of a reference frother respectively.

The correlation among IDFI value, normalized frothability index, NFI, and normalized bubble collapse rate constant, $\mathrm{NK}_{\mathrm{c}}$, is shown in Figure 4-17. The NFI has a trend to reach a maximum value when IDFI value is in the range of 300-400. The normalized bubble collapse rate constant, $\mathrm{NK}_{\mathrm{c}}$, has an opposite effect for the corresponding IDFI ranges.

As shown in Figure 4-18, the combustible recovery increases with increasing NFI value and this effect becomes less pronounced as the flotation time increases. A solvent, which gives a high NFI value, yields both a high clean coal ash content and a high clean coal recovery. Figure 4-19 shows that clean coal ash content tends to decrease with increasing normalized bubble collapse rate constant, $\mathrm{NK}_{\mathrm{c}}$, because a higher bubble collapse rate can results in a lower ash clean coal. From the results of frothing tests and fine coal flotation tests, the normalized frothability index, NFI, can correlates well with the combustible recovery. Normalized bubble collapse rate constant, $\mathrm{NK}_{\mathrm{c}}$, can be used to find a trend of changes of concentrate ash content. However, both NFI and $\mathrm{NK}_{\mathrm{c}}$ are not related to froth dynamic properties. Thus they can not be used to explain appropriately the overall frothing properties of a solvent, the effect of frothability of solvent on combustible recovery and clean coal quality at the same time.

In Figure 4-17, 4-18 and 4-19, although a solvent with a IDFI value of $250 \sim 350$ gives a high normalized frothability index value and thus a high combustible recovery, it always results in a high ash coal concentrate due to corresponding low normalized bubble collapse rate constant. A solvent, which yields an IDFI value greater than 350 or less 


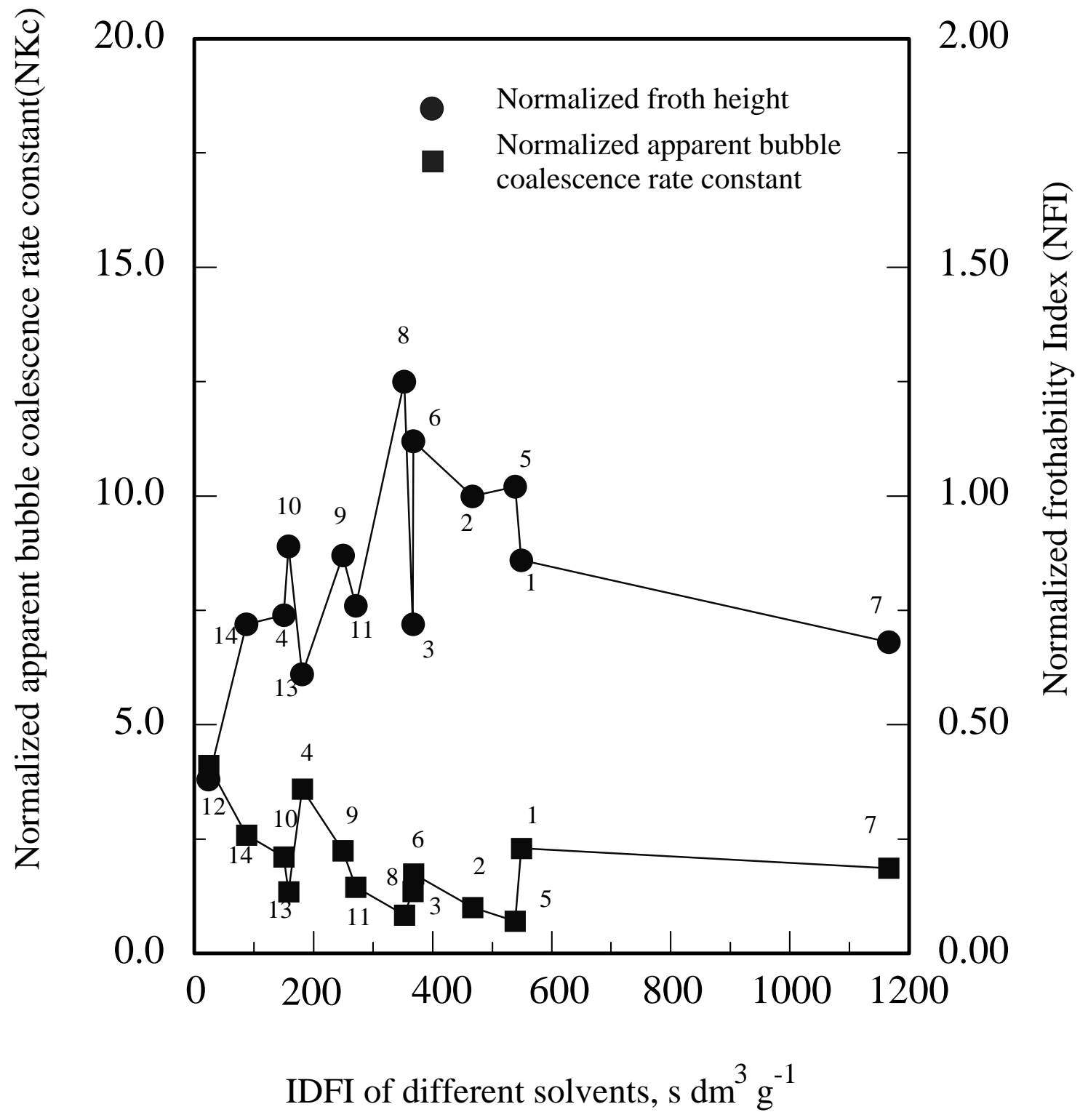

Figure 4-17 Normalized frothability index (NFI) and normalized apparent bubble coalescence rate constant (NKc) relative to MIBC as a function of IDFI 


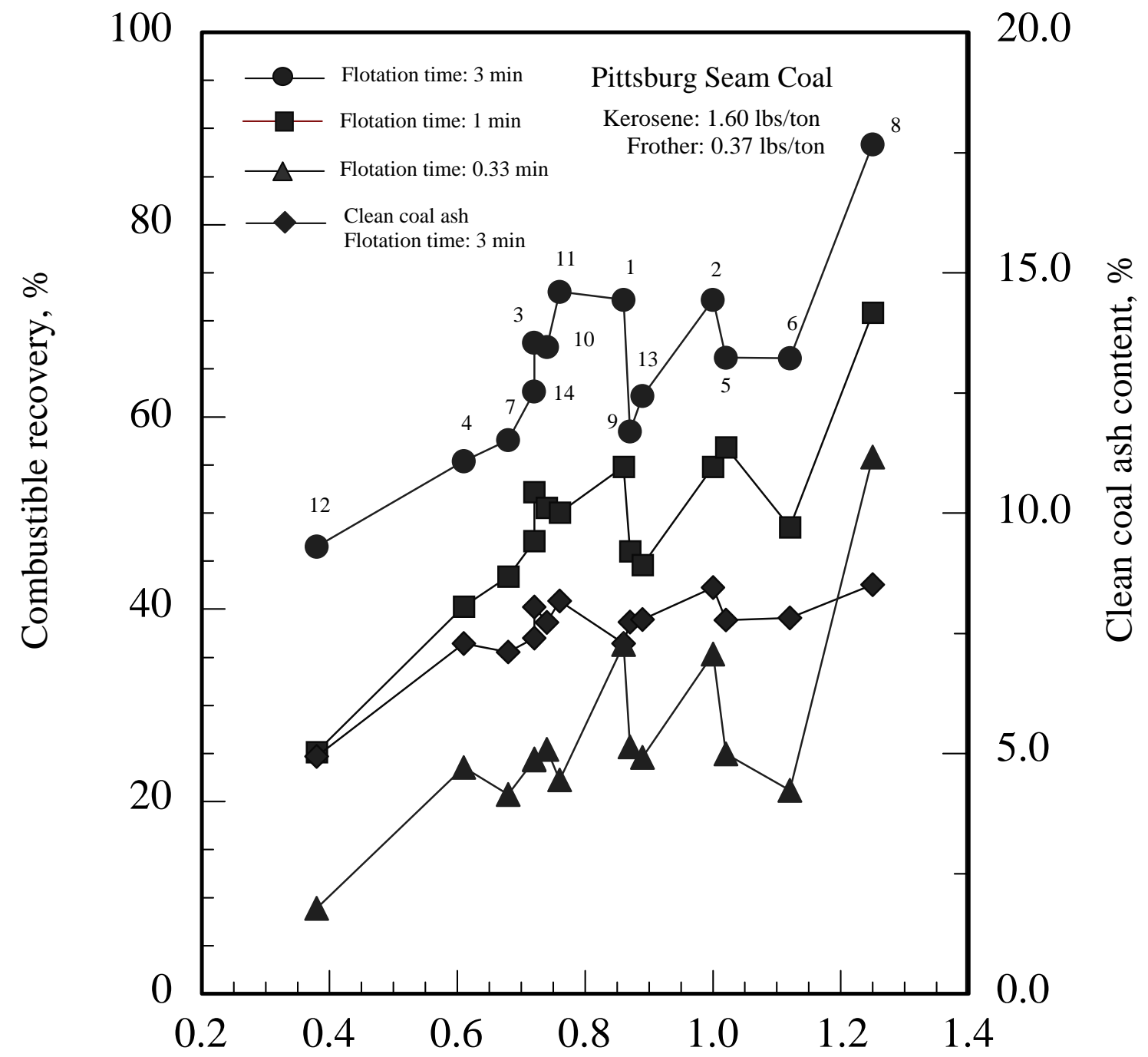

Normalized frothability Index (NFI)

Figure 4-18 Relationship of combustible recovery, clean coal ash content and normalized frothability index (NFI) relative to MIBC at different flotation time 


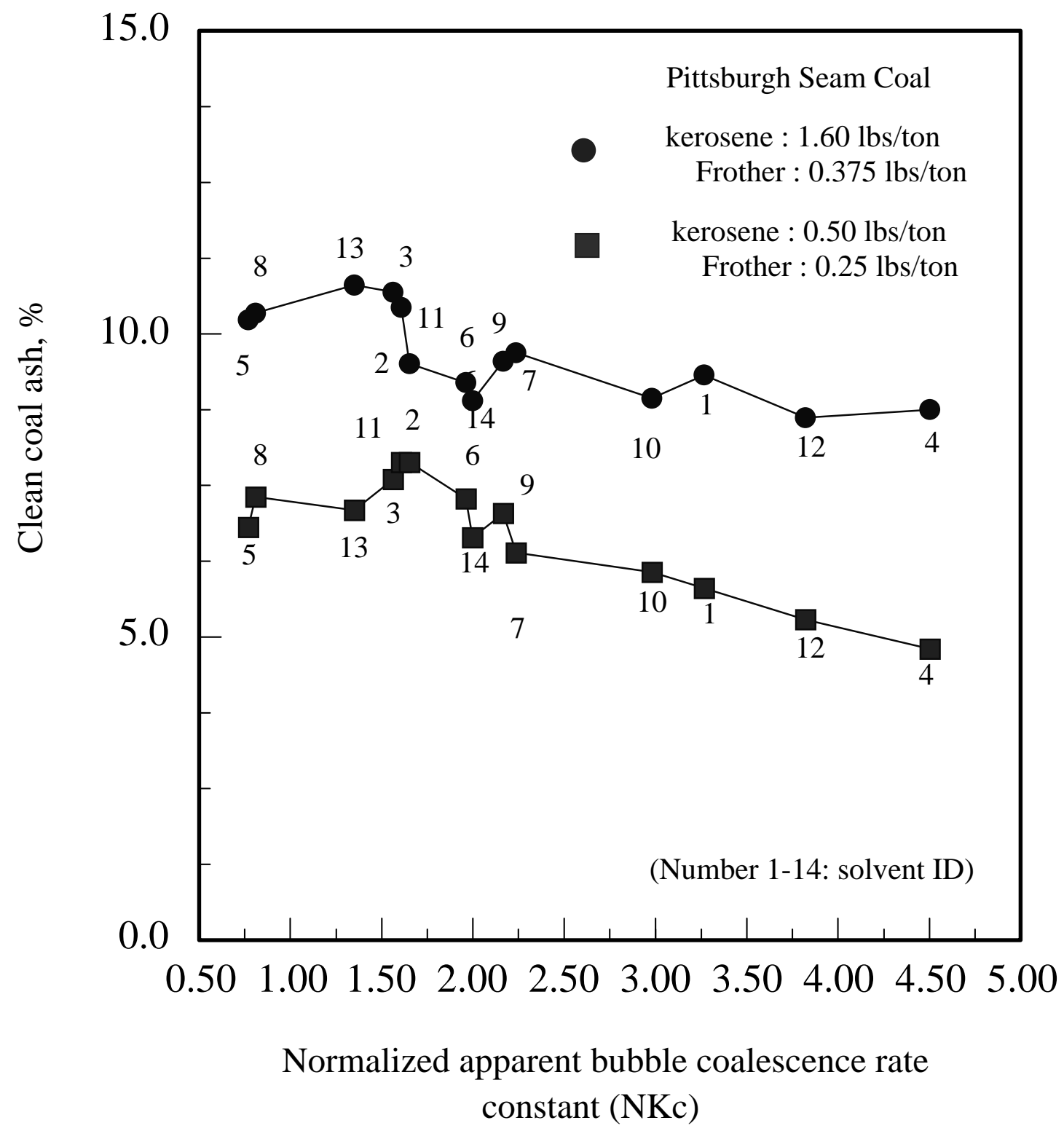

Figure 4-19 Relationship of clean coal ash\% and normalized apparent coalescence rate constant $(\mathrm{NKc})$ relative to MIBC 
than 250 , produces a reasonable high combustible recovery, while maintaining a good selectivity. On the other hand, a solvent, which yields too low or too high IDFI value, tends to produce a froth, which will produce a high ash clean coal and low clean coal yield.

Figure 4-20 shows the performance of various solvents on fine coal flotation, using $0.25 \mathrm{lbs} / \mathrm{ton}$ of solvent and $0.5 \mathrm{lbs} / \mathrm{ton}$ of kerosene. The higher combustible recovery is achieved for using Solvents 3, 8 and 11, but the corresponding ash recovery in clean coal product is relative high too, and thus the selectivity is not good enough. Although Solvents $1,4,7$, and 12 generates low ash clean coal, they also yield low ultimate combustible recovery. Solvents 5, 6, 9 and 10 can produce the froths, which yield a high ultimate combustible coal recovery and maintain a good selectivity. They are good frother candidates. Solvents 3, 8 and 11 can be the potential frothers used in rougher flotation, where a high recovery of useful minerals is expected. Solvents 1, 4, 7, and 12 can be considered as the potential frother candidates for cleaner flotation, where a highgrade concentrate is expected. Solvents 4 and 12 might be mixed with Solvent 7 to make a solvent blend with a medium ranged IDFI value, which might produce a good flotation response for fine coal and mineral recovery that are similar to those by using Solvents 5, 6,9 or 10 . 


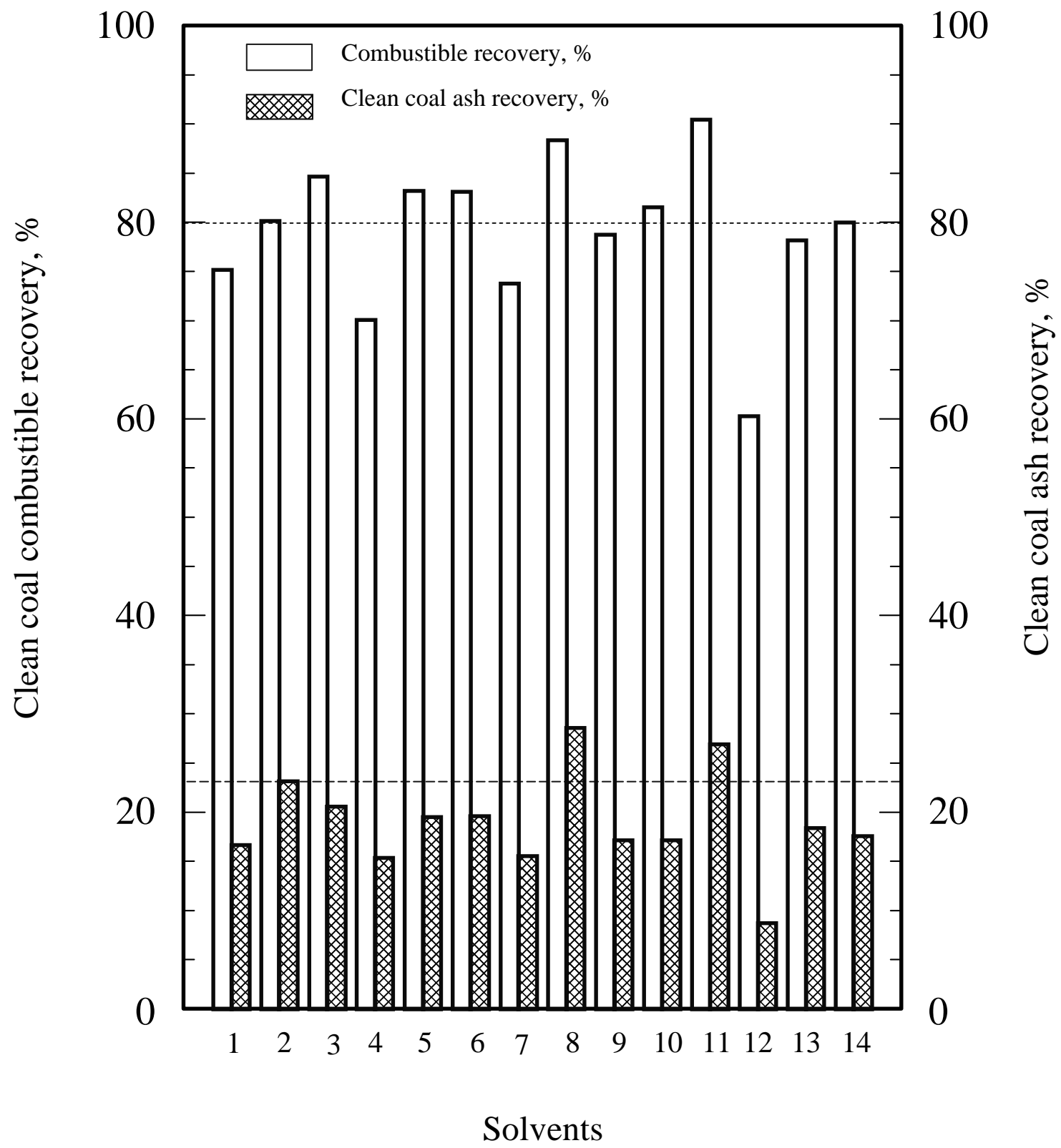

Figure 4-20 Flotation performance of fine coal using various solvents 


\section{CHAPTER 5}

\section{CONCLUSIONS}

The evaluating of fourteen solvents is conducted through the measurement of froth volume in a column froth meter and the batch test of fine coal flotation. The major conclusions derived from this work are presented as follows:

(1) The maximum rising velocity of a bubble can be taken as a measure of the terminal velocity and can be further used to estimate the retention time of the bubble in liquid. The retention time of froth decreases with increasing aeration rate or bubble size. When aeration rate or bubble size is large enough, the retention time of froth can be considered as constant, thus, there exists an approximate linear relationship between the froth height (or froth volume) and aeration rate. On the other hand, if the aeration rate or bubble size is small, the retention time will decrease with the aeration rate rather than being constant and there exists a non-linear relationship between the froth height (or volume) and aeration rate.

(2) For water and alcohol type frothers, froth height increases with aeration rate linearly because the froths consist of large loosely packed bubbles, which will show a constant retention time. Polyglycol ether type frothers can produce densely knit froth formed by small bubbles; thus, there exists a typical nonlinear relationship between the froth height and aeration rate.

(3) For polyglycol ether type frothers, considering the way in which froth retention time varies with aeration time even at a constant frother concentration, Initial Retention Time (IRT) is used instead of retention time to illustrate the frothability of frother. Further, Initial Dynamic Froth Index (IDFI) is proposed to evaluate frothing properties of tested solvents. It is defined as the limiting slope of the initial retention time versus concentration where concentration approaches zero. The product of IDFI and frother concentration gives the estimated initial retention time difference of froth between that in liquid and that in pure water. It gives the frothing properties of the solution studied under dynamic steady-state conditions.

(4) IDFI value depends not only on molecular weight, but also on molecular structure of solvents. Solvents in the same family with a higher molecular weight or with a lower Hydrophilic-Lipophilic Balance value (HLB) will result in a higher IDFI value. Increasing number of hydrophobic groups $\mathrm{PO}$ and $-\mathrm{CH}_{2}$ will increase IDFI values.

(5) The ultimate combustible recovery and kinetic rate constant are constant provided the frothers are applied in amounts assuring the same initial retention time (IDFI*C) value. Increasing the $\mathrm{IDFI}^{*} \mathrm{C}$ value may increase the fine coal recovery and kinetic rate constant. However, an excessive high $\mathrm{IDFI}^{*} \mathrm{C}$ value, may lead to reduction in selectivity and efficiency. 
(6) From the results of frothing tests and fine coal flotation tests, the normalized frothability index, NFI, correlates well with combustible recovery, and can be used to predict the trend of the combustible recovery. Normalized bubble collapse rate constant, $\mathrm{NK}_{\mathrm{c}}$, can be used to find a trend of changes of ash content in the clean coal product. Since both NFI and $\mathrm{NK}_{\mathrm{c}}$ are not related to froth dynamic properties, and they can not appropriately represent the overall frothing properties of a solvent. HLB value is direct related to the hydrophilic-hydrophobic properties of a solvent, but the difficulty in calculations of HLB values of solvents with aromatic group structures. Unsuccessful explanation of apparent frothing difference of frothers at the same HLB values limit its usage.

(7) A solvent (Solvent 3, 8 or 11) with an IDFI value of 250-350 yields a high coal recovery, but less selectivity. A solvent (Solvent 5, 6, 9 or 10) with an IDFI value slightly higher than 350 or less than 250 will yield a reasonably high combustible recovery while keeping good selectivity. A solvent, such as $1,4,7$ or 12 , with a too low or too high IDFI value tends to produce froths, which will yield higher ash content of clean coal product by sacrificing too much combustible recovery. Various solvents might be blended to achieve desired properties for better flotation performance through improved recovery and rate constant. 


\section{BIBLIOGRAPHY}

Crozier, R. D., January 1980, "Frother function in sulfide flotation," Mining Magzine, pp. 26-35.

Crozier, R. D. and Klimpel, R. R., 1989, "Frother: Plant practice," Mineral Proce. Ext. Metall. Rev., Vol. 5, pp. 257-279.

Crozier, R. D. and Ottley, D., April 1978, "Processing of copper sulfide ores. Flotation Reagents Review," Mining Magazine, pp. 332-339.

Dey, S., and Bhattacharya, S., 1998, "Comparative performance analysis of solvents-A review of available methodologies,” Mineral Proce. Ext. Metall. Rev., Vol. 18, pp. 201-213.

Dho, H. and Iwasaki, I., November 1990, "The role of sodium silicate in phosphate flotation," Mineral \& Metallurgical Processing, Vol. 32, pp. 215-221.

Fdhila, R. B. and P.C. Duineveld, 1996, "The effect of surfactant on the rise of a spherical bubble at high Reyonalds and Peclet numbers," Phys. Fluids, Vol. 8(2), pp. 310-320.

Hansen, R. D. and Klimpel, R. R., 1985, "Influence of frothers on particle size and selectivity in coal and sulfide mineral flotation," Trans. AIME, Vol. 280, pp. 1804-1811.

Huber-Panu, I. Ene-Danalache, E., and Cozocariu, D. G., "Mathematical models of batch and continuous flotation," Chapter 25, Flotation, Volume 2, ed by M. C. Fuerstenau, AIME, New York, NY, pp. 675-724.

Klimpel, R. R., Dec 1988, "Consideration for improving the performance of froth flotation systems," Mining Engineering, pp. 1093-1100.

Klimpel, R. R., 1995, "Gaudin award lecture--technology trends in froth flotation chemistry," Mining Engineering, Vol. 47, pp. 933-942.

Klimpel, R. R., 1999, "A review of sulfide mineral collector practice," "Advances in Flotation Technology," Edited by B. K. Parekh and J. D. Miller. SME Denver Colo., pp. 115-127.

Klimpel, R. R. and Hansen, R. D., 1987a, "Frothers," Reagents in Mineral Technology, P. Somasundaran and B. M. Moudgil, (eds.), Marcel Dekker, NewYork, NY. pp.663-681. 
Klimpel, R. R. and Hansen, R. D., 187b, "Chemistry of fine coal flotation," Fine Coal Processing, S. Mishra and R. Limpel, (eds.), Noyes Publishions, Park Ridge, NJ. pp. 78106.

Klimpel, R. R. and Hansen, R. D., 1988, “The interaction of flotation chemistry and size reduction in the recovery of a Prophyry copper ore," Int. J. of Miner. Process., Vol. 22, pp. 169-181.

Klimpel, R. R., and Isherwood, S., 1991, "Some industrial implications of changing frother chemical structure," Int. J. of Miner. Process., Vol. 33, pp. 369-381.

Langhlin, J. D. M., Quinn, P., Robertson, G. and Agur, G. E., May 1993, "Frother evaluation," XVIII Int. Mineral Proce. Congress, Sydney, pp. 23-28.

Laskowski, J. S., 1993, “Solvents and Flotation Froth,” Mineral Proce. Ext. Metall. Rev., Vol. 12, pp. 61-89.

Leja, J., 1989, “Interactions among surfactants,” Mineral Proce. Ext. Metall. Rev., Vol. 5, pp.1-24.

Leja, J. and Schulman, J. H., 1954, "Flotation Theory Molecular interactions between frothers and collectors at solid /liquid-/air interfaces," Trans. AIME., Min. Eng., Vol.16, pp. 221-228.

Malysa, E., Malysa, K. and Garnecki, J., 1987, "A method of comparison of the frothing and collecting properties of frothers," Colloids and Surface, Vol. 23, pp. 29-39.

Mclaughlin, John B., 1996, 'Numerical simulation of bubble motion in water," J. Colloid and Interface Science, Vol. 184, pp. 614-625.

Riggs, W. F., 1986, "Frothers-an operators guide", Chemical Reagents in the Mineral Processing Industry, D. Malhotra and W. F. Riggs (eds.), pp. 113-116.

Sam, A., Gomez, C. O. and Finch, J. A., 1996, "Axial velocity profiles of single bubbles in water/frother solutions,” Int. J. Miner. Process., Vol. 47, pp.177-196.

Schlichting, H., 1979, “Boundary layer theory," $7^{\text {th }}$ edition, McGraw-Hill. pp.201-203.

Smar, V. D., Klimpel, R. R. and Aplan, F. F., 1994, "Evaluation of chemical and oprational variable for the flotation of a copper ore, Part I: collector concentration, frother concentration and air flow rate ," Int. J. Miner. Process. Vol. 42, pp. 225-240.

Sun, S. C., 1952, "Frothing characteristics of pine oil in flotation," Mining Engineering, Vol. 4(1), pp. 65-71. 
Warszynki, P., Jachimska, B. and Malysa, K., 1996, "Experimental evidence of the existence of non-equilibrium coverages over the surface of the floating bubble," Colloids and Surface A: Physicochem. Eng. Aspects, Vol.108, pp. 321-325.

Wrobel, S. A., 1953, "Power and stability of flotation frothers," Mine and Quarry Eng., Vol. 19, pp. 314-318.

Yoon, R. H. and Luttrell, G. H., 1989, "The effect of bubble size on fine particle flotation," Mineral Proce. Ext. Metall. Rev., Vol. 5, pp. 101-122.

Yoshiaki Numata, Feb 25-28, 1991, "Fundamental studies of the action of frother and collecting agents on the flotation of sulfide minerals," SME Annual meeting, Denver, CO., pp. 1-5.

Zhou, Z. A., Egiebor, N. O. and Plitt, L. R., 1992, "Frother effects on single bubble motion in a water column," Canadian Metallurgical Quaetery, Vol. 31 (1), pp. 11-16.

Wang, D., 1982, "Flotation reagent----Fundamentals and application," Beijing, (Chineses) pp. 197-200. 


\section{Appendix A}

\section{Physical and Chemical Properties of Solvents}




\section{Appendix A Physical and Chemical Properties of Solvents}

Table A-1 Physical and Chemical properties of Solvents

\begin{tabular}{|c|c|c|}
\hline $\begin{array}{l}\text { CHEMICAL PRODUCT AND } \\
\text { COMPANY IDENTIFICATION }\end{array}$ & Solvent 1 & Solvent 2 \\
\hline Product Name & TAFT OXO MIXTURE(unfiltered) & METHYL AMYL ALCOHOL \\
\hline Chemical Name & Not applicable (mixture) & 4-Methyl-2-Pentanol \\
\hline Common Family & Oxygenated Hydrocarbons & Alcohols \\
\hline Common Name & Taft OXO Mixture & Methyl Amyl Alcohol \\
\hline Formular & Not applicable (Mixture) & $\left(\mathrm{CH}_{3}\right)_{2} \mathrm{CHCH}_{2} \mathrm{CH}(\mathrm{OH}) \mathrm{CH}_{3}$ \\
\hline Molecular & & $102.18 \mathrm{~g} / \mathrm{mol}$ \\
\hline synonym & None & Methyl Isobutyl Carbinol MIBC \\
\hline Hazards of products & Danger! Extremely flammable, eye burns skin irritation & Warning! Eye irritation combustible \\
\hline \multicolumn{3}{|l|}{ COMPONENT INFORMATION } \\
\hline & Isobutanol & Methylisobutylcarbinol $100.0 \%$ \\
\hline & 2-ethyl-3-hydroxyhexyl ester butanoic acid $\quad>=2 . \%<=50 . \%$ & \\
\hline & Butyraldehyde (dimers, tetramers, pentamers) $>=2 .<=40 . \%$ & \\
\hline & Butanol $>=5 .<=30 . \%$ & \\
\hline & $>=5 .<=30 . \%$ & \\
\hline & $>=2 .<=20 . \%$ & \\
\hline & Butanoic acid & \\
\hline & 2-methyl-propanel & \\
\hline \multicolumn{3}{|l|}{$\begin{array}{l}\text { PHYSICAL AND CHEMICAL } \\
\text { PROPERTIES }\end{array}$} \\
\hline Physical State & Liquid & Liquid \\
\hline Appearance & Transparent colorless to green & Transparent colorless \\
\hline $\mathrm{pH}$ & NAV & NAV \\
\hline Solubility in Water(w\%) & $25^{\circ} \mathrm{C} \quad 7 \%$ & $20^{\circ} \mathrm{C} 1.7 \%$ \\
\hline Odor & Pungent, Sweet & Mild nonresidual \\
\hline Flash Point- Closed Cup & $-8^{\circ} \mathrm{C} \sim 18^{\circ} \mathrm{F}$ & $39^{\circ} \mathrm{C} \quad 102^{\circ} \mathrm{F}$ \\
\hline Boiling Point $(760 \mathrm{mmHg})$ & $85^{\circ} \mathrm{C}, 185^{\circ} \mathrm{F}$ & $131.7^{\circ} \mathrm{C} \quad 269^{\circ} \mathrm{F}$ \\
\hline Freezing Point & $<-50^{\circ} \mathrm{C},<-58^{\circ} \mathrm{F}$ & $-90^{\circ} \mathrm{C} \quad-130^{\circ} \mathrm{F}$ \\
\hline Specific Gravity $\left(\mathrm{H}_{2} \mathrm{O}=1\right)$ & $0.86120^{\circ} \mathrm{C} / 20^{\circ} \mathrm{C}$ & $0.807520^{\circ} \mathrm{C} / 20^{\circ} \mathrm{C}$ \\
\hline Vapor pressure at $20^{\circ} \mathrm{C}$ & $21.1^{\circ} \mathrm{C} 1.993 \mathrm{kPa} \quad 14.95 \mathrm{mmmHg}$ & $0.49 \mathrm{kPa} 3.7 \mathrm{mmHg}$ \\
\hline Vapor Density (air $=1$ ) & $>1$ & 3.5 \\
\hline Evaporation Rate (Butyl Acetate =1) & $1-2$ & 0.43 \\
\hline Melting Point & NA & NA \\
\hline
\end{tabular}


Table A-2 Physical and Chemical properties of Solvents

\begin{tabular}{|c|c|c|}
\hline $\begin{array}{l}\text { CHEMICAL PRODUCT AND } \\
\text { COMPANY IDENTIFICATION }\end{array}$ & Solvent 3 & Solvent 4 \\
\hline Product Name & "BUTOXYTRIGLYCOL & "ETHOXYTRIGLYCOL \\
\hline Chemical Name & 2-\{2-(2-Butoxyethoxy)ethoxyethanol $\}$ & 2-\{2-(2-Ethoxyethoxy)ethoxy ethanol $\}$ \\
\hline Common Family & Glycol Ethers & Glycol Ethers \\
\hline Common Name & BUTOXYTRIGLYCOL & Ethoxytriglycol \\
\hline Formular & $\mathrm{CH}_{3} \mathrm{CH}_{2} \mathrm{CH}_{2} \mathrm{CH}_{2} \mathrm{O}\left(\mathrm{CH}_{2} \mathrm{CH}_{2} \mathrm{O}\right)_{3} \mathrm{H}$ & $\mathrm{CH}_{3} \mathrm{CH}_{2} \mathrm{O}\left(\mathrm{CH}_{2} \mathrm{CH}_{2} \mathrm{O}\right)_{3} \mathrm{H}$ \\
\hline Molecular weight & $206.3 \mathrm{~g} / \mathrm{mol}$ & $178.2 \mathrm{~g} / \mathrm{mol}$ \\
\hline synonym & Triethylene glycol monobutyl ether & Triethylene glycol monoethyl ether \\
\hline Hazards of products & Warning! Eye irritation & Normal precautions \\
\hline \multirow[t]{5}{*}{ COMPONENT INFORMATION } & Triethylene glycol monobutyl ether $>=85 .<=100 . \%$ & $\begin{array}{l}\text { Triethlene glycol monoethyl ether } \\
>=85 .<=90 . \%\end{array}$ \\
\hline & Tetraethylene glycol monobutyl ether $<=8 . \%$ & $\begin{array}{l}\text { Tetraethlene glycol monoethyl } \\
\text { ether }>=0.1<=15 . \%\end{array}$ \\
\hline & Diethylene glycol monobutyl ether $<=4 . \%$ & $\begin{array}{l}\text { Diethylene glycol monoethyl ether } \\
>=0.1<=4 . \%\end{array}$ \\
\hline & Triethylene glycol <=2.\% & $\begin{array}{l}\text { Diethylene glycol } \\
>=0.1<=3 . \%\end{array}$ \\
\hline & Ethylene glycol monobutyl ether $<=0.3 \%$ & $\begin{array}{l}\text { Triethylene glycol } \\
>=0.1<=2.5 \%\end{array}$ \\
\hline \multicolumn{3}{|l|}{$\begin{array}{l}\text { PHYSICAL AND CHEMICAL } \\
\text { PROPERTIES }\end{array}$} \\
\hline Physical State & Liquid & Liquid \\
\hline Appearance & Transparent colorless & Transparent colorless \\
\hline $\mathrm{pH}$ & 7.5 & NAV \\
\hline Solubility in Water(w\%) & $20^{\circ} \mathrm{C} 100 \%$ & $20^{\circ} \mathrm{C} 100 \%$ \\
\hline Odor & Mild & Pungent \\
\hline Flash Point- Closed Cup & $137.7^{\circ} \mathrm{C} 280^{\circ} \mathrm{F}$ & $129^{\circ} \mathrm{C} \quad 265^{\circ} \mathrm{F}$ \\
\hline Boiling Point $(760 \mathrm{mmHg})$ & $283.2^{\circ} \mathrm{C} 541.8^{\circ} \mathrm{F}$ & $255.9^{\circ} \mathrm{C} 492.6^{\circ} \mathrm{F}$ \\
\hline Freezing Point & $-39^{\circ} \mathrm{C}-38^{\circ} \mathrm{F}$ & $-23^{\circ} \mathrm{C}-10^{\circ} \mathrm{F}$ \\
\hline Specific Gravity $\left(\mathrm{H}_{2} \mathrm{O}=1\right)$ & $0.98920^{\circ} \mathrm{C} / 20^{\circ} \mathrm{C}$ & $1.02320^{\circ} \mathrm{C} / 20^{\circ} \mathrm{C}$ \\
\hline Vapor pressure at $20^{\circ} \mathrm{C}$ & $<0.001 \mathrm{kPa}<0.01 \mathrm{mmHg}$ & $<0.001 \mathrm{kPa}<0.01 \mathrm{mmHg}$ \\
\hline Vapor Density (air $=1)$ & 7 & 6 \\
\hline Evaporation Rate (Butyl Acetate $=1$ ) & $<0.01$ & $<0.01$ \\
\hline Melting Point & NA & NA \\
\hline
\end{tabular}


Table A-3 Physical and Chemical properties of Solvents

\begin{tabular}{|c|c|c|}
\hline $\begin{array}{l}\text { CHEMICAL PRODUCT AND } \\
\text { COMPANY IDENTIFICATION }\end{array}$ & Solvent 5 & Solvent 6 \\
\hline Product Name & "HEXYL CARBITOL SOLVENT & ECOSOFT( TM) Solvent PH \\
\hline Chemical Name & 2-(2-hexyloxy ethoxyl) ethanol & NA (mixture) \\
\hline Common Family & Glycol Ethers & Glycol Ethers \\
\hline Common Name & & SOLVENT PH \\
\hline Formula & $\mathrm{CH}_{3} \mathrm{CH}_{2} \mathrm{CH}_{2} \mathrm{CH}_{2} \mathrm{CH}_{2} \mathrm{CH}_{2} \mathrm{O}\left(\mathrm{CH}_{2} \mathrm{CH}_{2} \mathrm{O}\right)_{2} \mathrm{H}$ & NA (mixture) \\
\hline Molecular weight & $190.3 \mathrm{~g} / \mathrm{mol}$ & \\
\hline synonym & Diethylene glycol monohexyl ether & None \\
\hline \multicolumn{3}{|l|}{ Hazards of products } \\
\hline \multirow[t]{5}{*}{ COMPONENT INFORMATION } & Diethylene glycol monohexyl ether 97-100\% & $\begin{array}{l}\text { Triethylene glycol monohexyl ether } \\
>=40 .<=85 \%\end{array}$ \\
\hline & Ethylene glycol monohexyl ether $0-1 \%$ & $\begin{array}{l}\text { Polyethylene glycol monohexyl } \\
\text { ether }>=5 .<=25 \%\end{array}$ \\
\hline & Triethylene glycol monohexyl ether $0-1 \%$ & $\begin{array}{l}\text { Diethylene glycol monohexyl } \\
\text { ether }<=25 \%\end{array}$ \\
\hline & Diethylene glycol $0-1 \%$ & Sodium hydroxide $<0.9 \%$ \\
\hline & Triethylene glycol 0-1\% & \\
\hline \multicolumn{3}{|l|}{$\begin{array}{l}\text { PHYSICAL AND CHEMICAL } \\
\text { PROPERTIES }\end{array}$} \\
\hline Physical State & Liquid & Liquid \\
\hline Appearance & Transparent colorless & Transparent colorless to amber \\
\hline $\mathrm{pH}$ & & NAV \\
\hline Solubility in Water(w\%) & $3 \%$ & $100 \% 20^{\circ} \mathrm{C}$ \\
\hline Odor & Sweet & Pungent \\
\hline Flash Point- Closed Cup & $132.8^{\circ} \mathrm{C} \quad 271^{\circ} \mathrm{F}$ & $157.2^{\circ} \mathrm{C} \quad 315^{\circ} \mathrm{F}$ \\
\hline Boiling Point $(760 \mathrm{mmHg})$ & $259.1^{\circ} \mathrm{C} 498.7^{\circ} \mathrm{F}$ & $289.9^{\circ} \mathrm{C} 533.8^{\circ} \mathrm{F}$ \\
\hline Freezing Point & $-40^{\circ} \mathrm{C} \quad-40.4^{\circ} \mathrm{F}$ & $-33^{\circ} \mathrm{C} \quad-27^{\circ} \mathrm{F}$ \\
\hline Specific Gravity $\left(\mathrm{H}_{2} \mathrm{O}=1\right)$ & $0.93520^{\circ} \mathrm{C} / 20^{\circ} \mathrm{C}$ & $0.93-0.97 \quad 20^{\circ} \mathrm{C} / 20^{\circ} \mathrm{C}$ \\
\hline Vapor pressure at $20^{\circ} \mathrm{C}$ & $<0.01 \mathrm{mmHg}$ & $<0.01 \mathrm{mmHg}$ \\
\hline Vapor Density (air $=1$ ) & 7 & 8 \\
\hline Evaporation Rate (Butyl Acetate $=1$ ) & $<0.01$ & $<0.01$ \\
\hline Melting Point & NA & NA \\
\hline
\end{tabular}


Table A-4 Physical and Chemical properties of Solvents

\begin{tabular}{|c|c|c|}
\hline $\begin{array}{l}\text { CHEMICAL PRODUCT AND } \\
\text { COMPANY IDENTIFICATION }\end{array}$ & Solvent 7 & Solvent 8 \\
\hline Product Name & "TAFT OXO MIXTURE & ECOSOFT(TM) Solvent PB \\
\hline Chemical Name & Not applicable (mixture) & Mixture \\
\hline Common Family & Oxygenated hydrocarbons & Glycol ethers \\
\hline Common Name & Taft OXO Mixture & SOLVENT PB \\
\hline Formular & NA & NA ( mixture) \\
\hline \multicolumn{3}{|l|}{ Molecular weight } \\
\hline synonym & None & None \\
\hline \multicolumn{3}{|l|}{ Hazards of products } \\
\hline COMPONENT INFORMATION & Isobutanol $<=50 \%$ & $\begin{array}{l}\text { Polyethylene glycol monobutyl ether } \\
>=98 .,=99 . \%\end{array}$ \\
\hline & 2-ethyl-3-hydroxyhexyl ester butanoic acid $>=2 .<=50 \%$ & Tetraethyle glycol.$=1 .<=2 . \%$ \\
\hline & Butyraldehyde (dimers, tetramers, pentamers) $>=2 .<=40 \%$ & \\
\hline & Butanol $>=5 .<=30 \%$ & \\
\hline & Butyl butyrate $>=5 .<=30 \%$ & \\
\hline & Butanal $>=2 .<=20 \%$ & \\
\hline & Butanoic acid $<=10 \%$ & \\
\hline & 2-methyl-1-propanal <=2\% & \\
\hline \multicolumn{3}{|l|}{$\begin{array}{l}\text { PHYSICAL AND CHEMICAL } \\
\text { PROPERTIES }\end{array}$} \\
\hline Physical State & Liquid & Liquid \\
\hline Appearance & Transparent colorless to green & Transparent colorless to pale yellow \\
\hline $\mathrm{pH}$ & Not currently available & Not currently available \\
\hline Solubility in Water(w\%) & $7 \% \quad 25^{\circ} \mathrm{C}$ & $100 \% 20^{\circ} \mathrm{C}$ \\
\hline Odor & Pungent, Sweet & Pungent \\
\hline Flash Point- Closed Cup & $-8 \sim 18^{\circ} \mathrm{C}$ & $\sim 165^{\circ} \mathrm{C} \quad 568.6^{\circ} \mathrm{F}$ \\
\hline Boiling Point $(760 \mathrm{mmHg})$ & $85^{\circ} \mathrm{C} \quad 185^{\circ} \mathrm{F}$ & $187.7^{\circ} \mathrm{C} \quad 370{ }^{\circ} \mathrm{F}$ \\
\hline Freezing Point & $<-50^{\circ} \mathrm{C}<-58^{\circ} \mathrm{F}$ & $-28^{\circ} \mathrm{C}-18^{\circ} \mathrm{F}$ \\
\hline Specific Gravity $\left(\mathrm{H}_{2} \mathrm{O}=1\right)$ & $0.86120^{\circ} \mathrm{C} / 20^{\circ} \mathrm{C}$ & 1.005 \\
\hline Vapor pressure at $20^{\circ} \mathrm{C}$ & $14.95 \mathrm{mmHg}$ & $<0.01 \mathrm{mmHg}$ \\
\hline Vapor Density (air $=1)$ & $>1$ & 8 \\
\hline Evaporation Rate (Butyl Acetate $=1$ ) & & $<0.01$ \\
\hline Melting Point & & ND \\
\hline
\end{tabular}


Table A-5 Physical and Chemical properties of Solvents

\begin{tabular}{|c|c|c|}
\hline $\begin{array}{l}\text { CHEMICAL PRODUCT AND } \\
\text { COMPANY IDENTIFICATION }\end{array}$ & Solvent 9 & Solvent 10 \\
\hline Product Name & ECOSOFT (MT) Solvent PE & "TAXAS CITY OXO MIXTURE \\
\hline Chemical Name & Not applicable (mixture) & \\
\hline Common Family & Glycol Ethers & \\
\hline Common Name & ECOSOFT TM Solvent PE & \\
\hline Formula & Not applicable (mixture) & \\
\hline \multicolumn{3}{|l|}{ Molecular weight } \\
\hline synonym & Ethoxytriglycol-ethoxytetraglycol mixture & \\
\hline \multicolumn{3}{|l|}{ Hazards of products } \\
\hline \multirow{5}{*}{ COMPONENT INFORMATION } & Polyethylene glycol monoethyl ether $>50<=90 . \%$ & 2-Ethylhexyl alcohol \\
\hline & Triethylene glycol monoethyl ether $<=25 \%$ & Octyl alcohol \\
\hline & Polyethylene glycol <2.\% & Butanol, 2Methylbutanol etc. \\
\hline & Diethylene glycol monoethyl ether $<1 \%$ & $\begin{array}{l}\text { Recovered Ethyl } \\
\text { Propyl Acrolein }\end{array}$ \\
\hline & & Butanol Heavies Column Tails \\
\hline & & \\
\hline & & \\
\hline \multicolumn{3}{|l|}{$\begin{array}{l}\text { PHYSICAL AND CHEMICAL } \\
\text { PROPERTIES }\end{array}$} \\
\hline Physical State & Liquid & \\
\hline Appearance & Transparent yellow & \\
\hline $\mathrm{pH}$ & 6.4 & \\
\hline Solubility in Water(w\%) & $100 \% 20^{\circ} \mathrm{C}$ & \\
\hline Odor & Sweet & \\
\hline Flash Point- Closed Cup & $143^{\circ} \mathrm{C} \quad 290^{\circ} \mathrm{F}$ & \\
\hline Boiling Point $(760 \mathrm{mmHg})$ & $310^{\circ} \mathrm{C} \quad 590^{\circ} \mathrm{F}$ & \\
\hline Freezing Point & $-15^{\circ} \mathrm{C} \quad 5^{\circ} \mathrm{F}$ & \\
\hline Specific Gravity $\left(\mathrm{H}_{2} \mathrm{O}=1\right)$ & $1.04420^{\circ} \mathrm{C} / 20^{\circ} \mathrm{C}$ & \\
\hline Vapor pressure at $20^{\circ} \mathrm{C}$ & $<0.01 \mathrm{mmHg}$ & \\
\hline Vapor Density (air $=1)$ & 8 & \\
\hline Evaporation Rate (Butyl Acetate $=1$ ) & $<0.01$ & \\
\hline Melting Point & NAV & \\
\hline
\end{tabular}


Table A-6 Physical and Chemical properties of Solvents

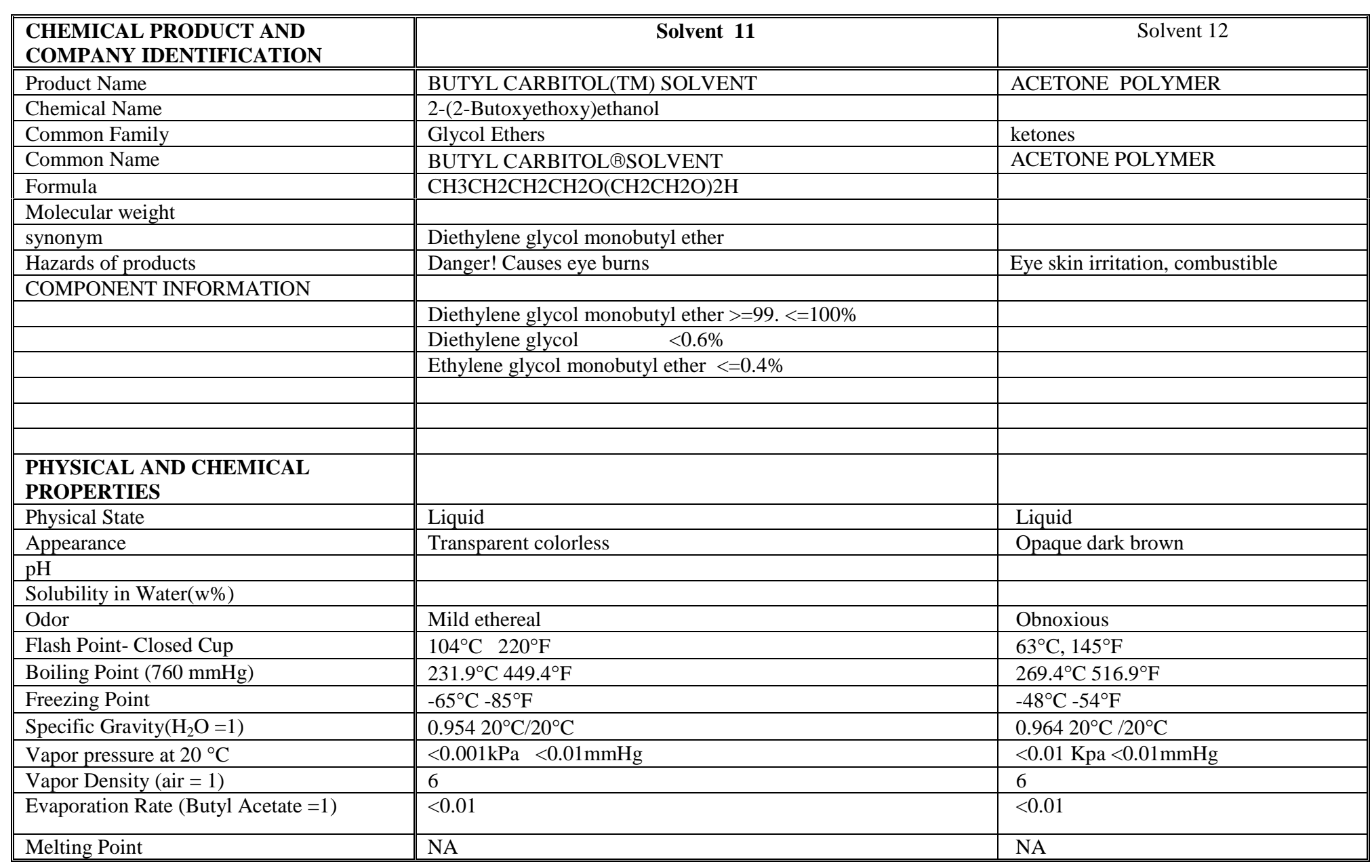




\section{Appendix B}

Step Growth Model for Bubble Coalescence 


\section{Appendix B Step Growth Model for Bubble Coalescence}

1. Bubble Size Distribution and Coalesce

In a froth column meter, there are $\mathrm{N}_{\mathrm{o}}$ original bubbles of some frothers in column at the time $t=0$. Each bubble has a diameter of $D_{o}$ and a volume of $v$, at time $t$, there is number of $\mathrm{N}$ of bubbles left with diameter of $\mathrm{D}_{\mathrm{o}}$. The percent of coalesce, $\mathrm{P}$, is:

$$
\mathrm{P}=\frac{\mathrm{N}_{\mathrm{o}}-\mathrm{N}}{\mathrm{N}_{\mathrm{o}}}
$$

As time goes on, the bubbles will coalesces with each other. Two bubbles coalesce together to form a larger bubble with a volume of $2 \mathrm{v}$, its number is $\mathrm{n}_{2}$, similarly, $\mathrm{n}_{3}$ is the number of bubbles with a volume of $3 \mathrm{v} \ldots$ Thus, the number of bubbles at any time will be $\mathrm{N}$,

$$
\mathrm{N}=\sum_{\mathrm{x}=1}^{\mathrm{M}} \mathrm{n}_{\mathrm{x}}
$$

where $\mathrm{M}$ is the diameter ratio of the largest bubble to the bubble with a diameter $\mathrm{D}_{\mathrm{o}}$.

The probability had a bubble picked up at random has a volume of $x v$ is $n_{x} / N$. Since $(\mathrm{No}-\mathrm{N})$ is the total number reduction in bubbles and the total number of coalesced bubbles is (No-N). Thus, probability of finding coalesced bubble is (No-N)/No, also probability of finding an un-coalesced bubble is $1-\left(\mathrm{N}_{0}-\mathrm{N}\right) / \mathrm{N}_{\mathrm{o}}=\mathrm{N} / \mathrm{N}_{0}$.

A bubble with a volume of $x v$ can be treated as the coalescence between these two bubbles. One bubble with a volume of $(\mathrm{x}-1) \mathrm{v}$ and the other one with $\mathrm{v}$. Now each bubble in the column has 1 un-colasced bubble $B_{1}$ and $(x-1)$ coalesced bubbles $B_{x-1}$. Consequently, $\mathrm{n}_{\mathrm{x}} / \mathrm{N}$ is the probability of finding a bubble having 1 un-coalesced $\mathrm{B}_{1}$ and (x-1) coalesced $\mathrm{B}_{1}$ bubbles occurring simultaneously.

Probability that a bubble picked at random has a volume of $\mathrm{xv}$ is:

$$
\frac{\mathrm{n}_{\mathrm{x}}}{\mathrm{N}}=\left(\frac{\mathrm{No}-\mathrm{N}}{\mathrm{No}}\right)^{\mathrm{x}-1}\left(1-\frac{\mathrm{No}-\mathrm{N}}{\mathrm{No}}\right)=\mathrm{P}^{\mathrm{x}-1}(1-\mathrm{P})
$$

The volume fraction of the bubbles with a volume of $\mathrm{xV}$ is:

$$
\mathrm{V}_{\mathrm{x}}=\frac{\mathrm{n}_{\mathrm{x}} \mathrm{xv}}{\mathrm{vN}_{\mathrm{o}}}=\mathrm{x} \frac{\mathrm{n}_{\mathrm{x}}}{\mathrm{N}_{\mathrm{o}}}=\mathrm{x} \frac{\mathrm{n}_{\mathrm{x}}}{\mathrm{N}} \cdot \frac{\mathrm{N}}{\mathrm{N}_{\mathrm{o}}}=\mathrm{xp}^{\mathrm{x}-1}(1-\mathrm{P})^{2}
$$

If $\mathrm{P}$ is fixed, the relationships of $\mathrm{nx} / \mathrm{N}$ versus $\mathrm{x}$ and $\mathrm{V}_{\mathrm{x}}$ versus $\mathrm{x}$ can be plotted. As shown in Figure B-1 and B-2, with the increasing of bubble coalescence percent, the bubble size distribution and volume fraction distribution will become more even.

\section{Bubble Coalescence Percent With the Time}

The general coalesce that takes place in column is

$$
\mathrm{B}_{\mathrm{m}}+\mathrm{B}_{\mathrm{n}}=\mathrm{B}_{\mathrm{n}+\mathrm{m}}
$$

where $B_{m}$ is the bubble with a volume of $m v$.

Assumption are made in the following analysis:

1. All coalesce are taken to be irreversible;

2. Bubble diffusion resistance can be neglected;

3. Equal coalesce ability hypothesis is valid.

For example, let $m+n=4$, the coalesce that leads to $B_{4}$ are: 


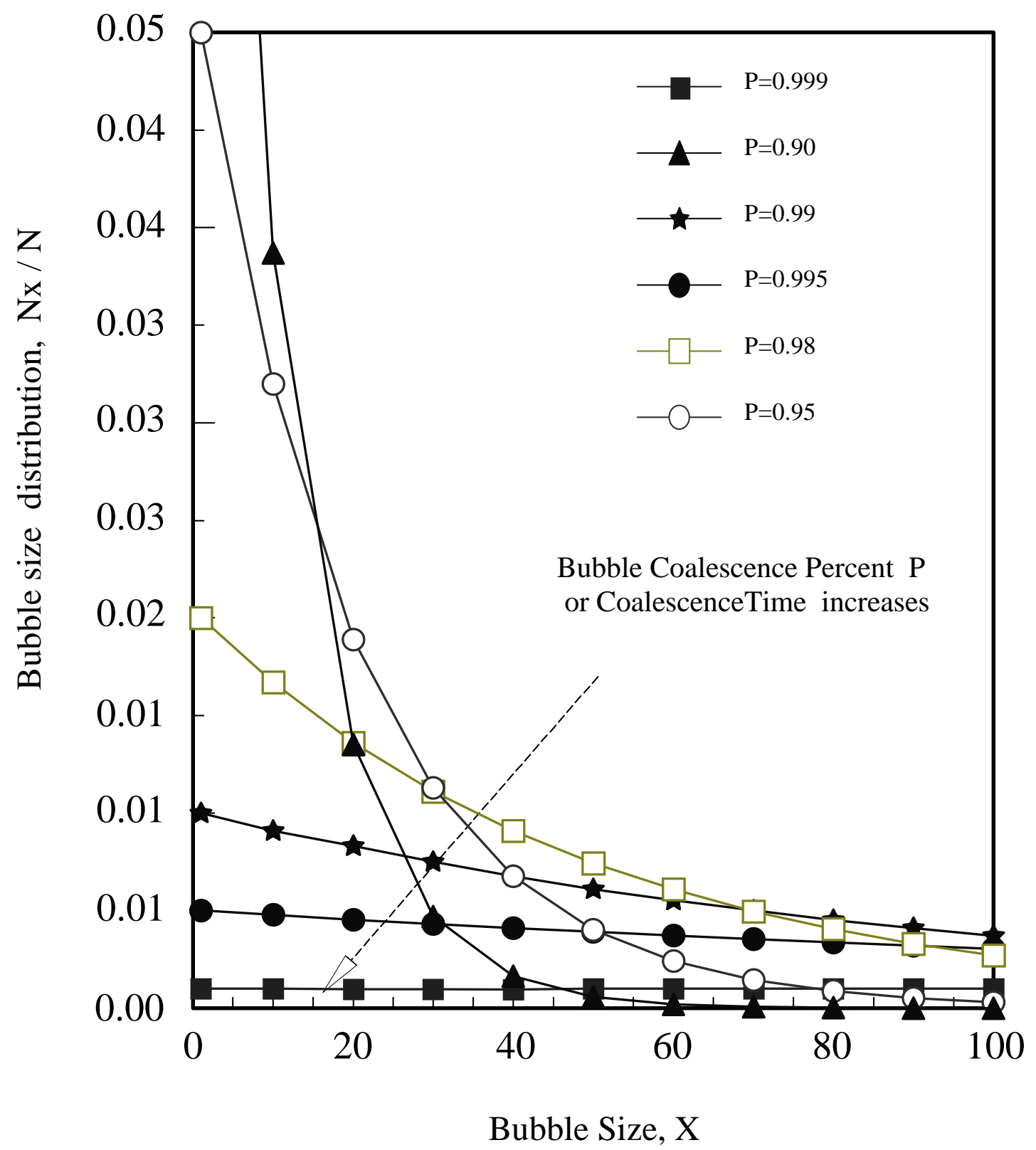

Figure B-1 The changes of bubble size distribution as a function of bubble coalescence percent or bubble coalescence time 


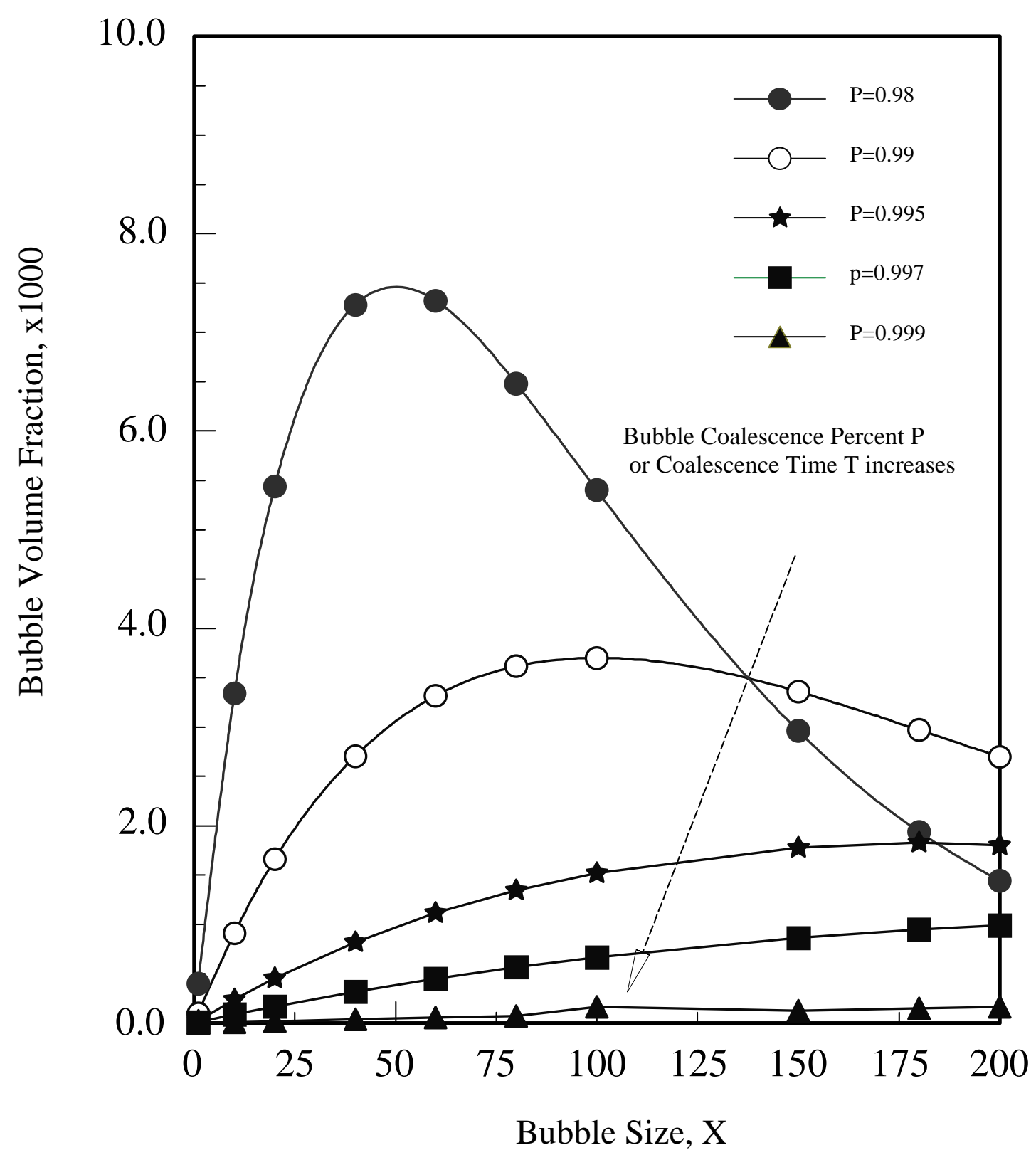

Figure B-2 The Changes of bubble volume fraction with bubbel coalescence percent or bubble coalescence time 


$$
\begin{aligned}
& B_{1}+B_{3}=B_{4} \\
& B_{2}+B_{2}=B_{4}
\end{aligned}
$$

Also, at same time, $\mathrm{B}_{4}$ disappears because of coalesce with other bubbles to form even larger bubble whose volume is larger than $4 \mathrm{v}$.

$$
\mathrm{B}_{4}+\mathrm{B}_{\mathrm{n}}=\mathrm{B}_{4+\mathrm{n}} \quad \mathrm{n}>=1,
$$

Let assume the coalesce reaction as following

$$
\mathrm{B}_{\mathrm{m}}+\mathrm{B}_{\mathrm{n}} \stackrel{2 \mathrm{k}}{\longrightarrow} \mathrm{B}_{\mathrm{m}+\mathrm{n}}
$$

where $\mathrm{K}$ is coalesce constant.

We want to determine the time variation of bubble size distribution.

$$
\lambda_{\mathrm{o}}=\sum_{\mathrm{n}=1}^{\infty}\left[\mathrm{B}_{\mathrm{n}}\right]
$$

where $\lambda_{\mathrm{o}}$ is the total number in liquid column and $\left[\mathrm{B}_{\mathrm{n}}\right]$ is concentration (number) of bubble with a volume of nv in a liquid column with a fixed volume.

The concentration of $\mathrm{B}_{1}$ changes with time.

$$
\begin{aligned}
\frac{d\left[B_{1}\right]}{d t} & =-2 k\left[B_{1}\right]\left\{\left[B_{1}\right]+\left[B_{2}\right]+\left[B_{3}\right]+\ldots+\left[B_{n}\right]+\ldots\right\} \\
& =-2 K\left[B_{1}\right] \sum_{n=1}^{\infty}\left[B_{n}\right]=-2 K\left[B_{1}\right] \lambda_{o}
\end{aligned}
$$

when $\mathrm{n}>1$,

$$
\begin{gathered}
\frac{\mathrm{d}\left[\mathrm{B}_{\mathrm{n}}\right]}{\mathrm{dt}}=\frac{1}{2} \times 2 \mathrm{~K}\left\{\left[\mathrm{~B}_{1}\right]\left[\mathrm{B}_{\mathrm{n}-1}\right]+\left[\mathrm{B}_{2}\right]\left[\mathrm{B}_{\mathrm{n}-2}\right]+\left[\mathrm{B}_{3}\right]\left[\mathrm{B}_{\mathrm{n}-3}\right]+\ldots+\left[\mathrm{B}_{\mathrm{m}}\right]\left[\mathrm{B}_{\mathrm{n}-\mathrm{m}}\right]+\ldots+\left[\mathrm{B}_{\mathrm{n}-1} \llbracket \mathrm{B}_{1}\right]\right\} \\
\frac{-2 \mathrm{~K}\left[\mathrm{~B}_{\mathrm{n}}\right]\left\{\left[\mathrm{B}_{1}\right]+\left[\mathrm{B}_{2}\right]+\left[\mathrm{B}_{3}\right]+\ldots\right\}}{\mathrm{dt}}=\mathrm{K} \sum_{\mathrm{i}=1}^{\mathrm{n}-1}\left[\mathrm{~B}_{1}\right]\left[\mathrm{B}_{\mathrm{n}-\mathrm{i}}\right]-2 \mathrm{~K}\left[\mathrm{~B}_{\mathrm{n}}\right] \lambda_{\mathrm{o}}
\end{gathered}
$$

Therefore,

$$
\begin{aligned}
\frac{\mathrm{d} \lambda}{\mathrm{dt}} & =\frac{\mathrm{d}\left[\mathrm{B}_{1}\right]}{\mathrm{dt}}+\sum_{\mathrm{n}=2}^{\infty} \frac{\mathrm{d}\left[\mathrm{B}_{\mathrm{n}}\right]}{\mathrm{dt}} \\
& =-2 \mathrm{~K}\left[\mathrm{~B}_{1}\right] \lambda_{0}+\mathrm{K} \sum_{\mathrm{n}=2}^{\infty} \sum_{\mathrm{r}=1}^{\mathrm{n}-1}\left[\mathrm{~B}_{\mathrm{r}}\right]\left[\mathrm{B}_{\mathrm{n}-\mathrm{r}}\right]-2 \mathrm{k} \lambda_{0} \sum_{\mathrm{n}=2}^{\infty}\left[\mathrm{B}_{\mathrm{n}}\right]
\end{aligned}
$$

Consider

$$
\begin{gathered}
\sum_{n=2}^{\infty} \sum_{r=1}^{n-1}\left[B_{r}\right]\left[B_{n-r}\right]=\left[B_{1}\right]^{2}+\left[B_{1}\right]\left[B_{2}\right]+\left[B_{2}\right]\left[B_{1}\right]+\left[B_{1}\right]\left[B_{3}\right]+\left[B_{2}\right]^{2}+\left[B_{3}\right]\left[B_{1}\right]+\ldots \\
=\left[B_{1}\right]^{2}+\left[B_{2}\right]^{2}+2\left[B_{1}\right]\left[B_{2}\right]+2\left[B_{3}\right]\left[B_{1}\right]+\ldots \\
=\left\{\left[B_{1}\right]+\left[B_{2}\right]+\left[B_{3}\right]+\ldots\right\}^{2}=\lambda_{0}{ }^{2} \\
\therefore \frac{d \lambda_{0}}{d t}=-2 k \lambda_{0}{ }^{2}+K \lambda_{0}{ }^{2}=-K \lambda_{0}{ }^{2}
\end{gathered}
$$

where 


$$
\lambda_{0}=\sum_{\mathrm{n}=1}^{\infty}\left[\mathrm{B}_{\mathrm{n}}\right]
$$

$\sum_{n=1}^{\infty}\left[B_{n}\right]$ is the total number concentration of un-coalesced bubble and it can be assumed as [B],

thus

$$
\begin{aligned}
& \frac{\mathrm{d}[\mathrm{B}]}{\mathrm{dt}}=-\mathrm{K}[\mathrm{B}]^{2} \\
& \int_{[\mathrm{B}]_{0}}^{[\mathrm{B}]} \frac{\mathrm{d}[\mathrm{B}]}{[\mathrm{B}]^{2}}=-\mathrm{K} \int_{0}^{\mathrm{t}} \mathrm{dt} \\
& \frac{1}{[\mathrm{~B}]}-\frac{1}{[\mathrm{~B}]_{0}}=\mathrm{Kt}
\end{aligned}
$$

From analysis of bubble volume fraction distribution, we know that if $\mathrm{P}$ increases, bubble size and volume fraction will allocated evenly. Thus, in testing of froth column meter, before compressed air is shut down, bubble size and bubble size distribution has already reached an equilibrium status of even distribution of bubble size and fraction volume.

$$
\begin{aligned}
{[\mathrm{B}]_{0} } & =\frac{\mathrm{N}_{0}}{\mathrm{~V}_{\text {column }}} \\
\mathrm{N}_{0} & =\sum_{\mathrm{i}=1}^{\mathrm{Max}} \mathrm{n}_{\mathrm{i}}
\end{aligned}
$$

where Max is the ratio of diameter of bubble at which the bubble breaks in air to the diameter of original bubble produced by fritted disc in froth column meter.

The total volume of bubble does not change in spite of bubble coalescence.

$$
\sum_{\mathrm{i}=1}^{\mathrm{Max}} \mathrm{i} \cdot \mathrm{n}_{\mathrm{i}} \mathrm{v}=\mathrm{H}_{0} \mathrm{~A}
$$

Bubble volume fraction distribution is even,

$$
\begin{gathered}
\mathrm{i} \cdot \mathrm{n}_{\mathrm{i}} \mathrm{v}=\frac{\mathrm{H}_{0} \mathrm{~A}}{\mathrm{Max}} \\
\mathrm{i} \cdot \mathrm{n}_{\mathrm{i}}=\frac{\mathrm{H}_{0} \mathrm{~A}}{\operatorname{Max} \cdot \mathrm{v}} \\
\mathrm{n}_{\mathrm{i}}=\frac{\mathrm{H}_{0} \mathrm{~A}}{\operatorname{Max} \cdot \mathrm{v}} \times \frac{1}{\mathrm{i}} \\
\mathrm{N}_{0}=\sum_{\mathrm{i}=1}^{\mathrm{Max}} \mathrm{n}_{\mathrm{i}}=\frac{\mathrm{H}_{0} \cdot \mathrm{A}}{\mathrm{v} \cdot \mathrm{Max}} \cdot \sum_{\mathrm{i}=1}^{\operatorname{Max}} \frac{1}{\mathrm{i}}
\end{gathered}
$$

Similarly, at time $\mathrm{t}$, we get

$$
[\mathrm{B}]=\frac{\mathrm{N}}{\mathrm{V}_{\text {column }}}
$$




$$
\begin{gathered}
\mathrm{N}=\frac{\mathrm{H} \cdot \mathrm{A}}{\mathrm{V} \cdot \mathrm{Max}} \cdot \sum_{\mathrm{j}=1}^{\mathrm{Max}} \frac{1}{\mathrm{j}} \\
\frac{1}{[\mathrm{~B}]_{0}}-\frac{1}{[\mathrm{~B}]}=\frac{\mathrm{V}_{\text {colume }} \cdot \mathrm{V}}{\mathrm{A}} \cdot \frac{\operatorname{Max}}{\sum_{\mathrm{i}=1}^{\operatorname{Max}} \frac{1}{\mathrm{i}}}\left(\frac{1}{\mathrm{H}_{0}}-\frac{1}{\mathrm{H}}\right) \\
\frac{\mathrm{V}_{\text {colume }}}{\mathrm{A}}=\mathrm{H}_{\text {liquid }} \\
\mathrm{V} \cdot \mathrm{H}_{\text {liquid }} \\
\cdot \frac{\mathrm{Max}}{\sum_{\mathrm{i}=1}^{\mathrm{Max}} \frac{1}{\mathrm{i}}}\left(\frac{1}{\mathrm{H}_{0}}-\frac{1}{\mathrm{H}}\right)=-\mathrm{Kt} \\
\frac{1}{\mathrm{H}}-\frac{1}{\mathrm{H}_{0}}=\mathrm{K}_{\mathrm{C}} \cdot \mathrm{t}
\end{gathered}
$$

where $\mathrm{K}_{\mathrm{C}}=\frac{\mathrm{K}}{\mathrm{v} \cdot \mathrm{H}_{\text {liquid }}} \times \frac{\sum_{\mathrm{i}=1}^{\operatorname{Max}_{1}} \frac{1}{\mathrm{i}}}{\operatorname{Max}}$. Thus, the reciprocal of froth height should show a linear relationship vs. time.

The bubble coalescence constant depends on bubble size, bubble distribution and liquid height. The surface tension determines bubble size, so the bubble coalescence constant is directly related to gas-liquid interface properties. 


\section{Appendix C \\ C Source Code for Determination for the Parameters of Flotation Rate Equation}




\section{Appendix C}

\section{Source Code for Determination for the Parameters of Flotation Rate Equation}

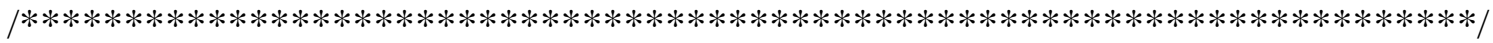

$1 *$

FROTHER EVALUATION paper.c

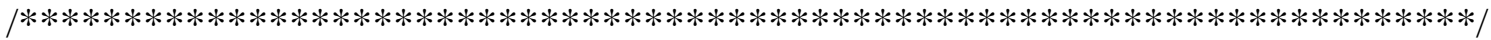

/* This program is used to calculate the flotation rate constant and ultimate */

$/ *$ in flotation test based on adopting Klimpel's kinetics model. In this program */

$/ *$ we used conjugate gradient method in searching the least sum of squares of $* /$

$/ *$ difference between calculated and observed ones.

/* After we have gotten the $\mathrm{k}$ at different collector dosages $\mathrm{C}$, then we used */

/* Least Sum of squares to compute the coefficients in linear regression. */

/*

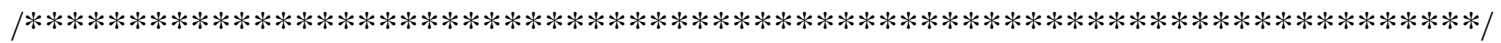

/* The main identifiers used in main function are: */

/* */

/* $\mathrm{Q}=$ parameter waited to be determined $\quad * /$

$/ * \quad$ ini_step $=$ the step in differentitaing of equations $\quad * /$

$/ *$ estimate $=$ the estimate error $\quad * /$

$/ *$ Collec_con $=$ collector concentration $\quad * /$

/* Rate = flotation rate constant */

$/ * \quad$ sum_square $=$ the calculated error $\quad * /$

$/ * \quad$ collec $=$ variables of collectors used in linear regression $\quad * /$

/* $\mathrm{R}=$ observed recovery value */

/* $\mathrm{T}=$ time at which the recovery is recorded $* /$

$/ * \quad$ con_num $=$ num of true collector levels $\quad * /$

/* $\mathrm{N}=$ num of parameters to be determined */

/* $\mathrm{M}=$ num of point pairs of $\mathrm{R}$ and $\mathrm{T}$

/* $\mathrm{N} 2=$ num of collector levels $\quad * /$

/* $\mathrm{M} 2=$ num of variable used in equations for linear regression */

/* */

/* The main identifier used in non linear regression are: */

$/ * \quad \mathrm{~N} 1$ = num of parameters waiting for being determined $\quad * /$

$/ * \mathrm{G}=$ gradient of function at one point $* /$

/* $\mathrm{P}=$ the searching direction $* /$

/* $\mathrm{F}=$ value of function */

/* $\mathrm{X}=$ the parameters waiting for being determined $\quad *$ /

$/ * \quad \mathrm{EST}=$ estimeted value of function $\quad * /$

/* MAXI $=$ the maximum times of iteration $\quad * /$

/ $* * * * * * * * * * * * * * * * * * * * * * * * * * * * * * * * * * * * * * * * * * * * * * * * * * * * * * * * * * * * * * * * * * * * * * * /$

/* PROGRAMMER: Yunkai Xia Date: Septmber 02, $2000 \quad *$ /

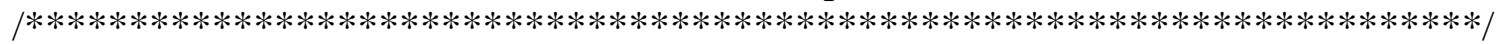


\#include<stdio.h>

\#include<stdlib.h>

\#include $<$ math.h>

\#define $\mathrm{N} 2$

\#define M 5

\#define N2 3

\#define M2 3

void instruct(void);

double FUNCT1( double X1[N], double R1[M], double T1[M]);

void GRAD(int N1, double X1[N], double G1[N], double DFIRST1[N], double R2[M], double T2[M],double FUNCT2(double X1[N], double R2[M], double T2[M]));

double DOT(int N1, double $\mathrm{A}[\mathrm{N}]$, double $\mathrm{B}[\mathrm{N}])$;

void none_linear( int *k, int N1,double X0[N],double X[N], double EST, double *RESULT, int MAXI, double DFIRST[N], double R3[M], double T3[M], double FUNCT(double X[N], double R3[M], double T3[M]));

void printout(double Collec_con, double $\mathrm{X}[\mathrm{N}]$, double sum_square, int $\mathrm{K}$ );

main ()

\{

int i,m,iteration_time,con_num, NUM=400;

double $\mathrm{Q}[\mathrm{N}]$, /* parameters in flotation test , at beginning of program, give the estimated value of factors in flotation test, such as recovery and flotation rate, when the execution of programe has ended, it will contain the final calculated value of parameters */

ini_step $[\mathrm{N}]=\{1 \mathrm{e}-3,1 \mathrm{e}-3\}, / *$ the step in differentiating of equentions $* /$

$\mathrm{Q} 0[\mathrm{~N}] ; /^{*}$ store the estimated value of factors in flotation test at beginning of program */

double estimate, $/ *$ the estimated error (sum of squares) between calculated value and observed one before calculation,when the execution of programe has ended, it will contain the final calculated value of error */

sum_square; $/ *$ the calculated error (sum of squares) between calculated value and observed one before calculation */ 
double $\mathrm{R}[\mathrm{M}], / *$ the observed recovery at time $\mathrm{T}$ in a test */

$\mathrm{T}[\mathrm{M}] ; / *$ the time at which the true recovery is recorded in a test $* /$

double Collec_con; /* concentration of collectors */

double Rate[N2]; /* Flotation rate constant */

double collec[N2][M2]; /* vaiables of collector used in linear regression */

char answer;

$/ *$ give instructions to users $* /$

instruct();

/* input the original data for none-linear regression compution */

do \{

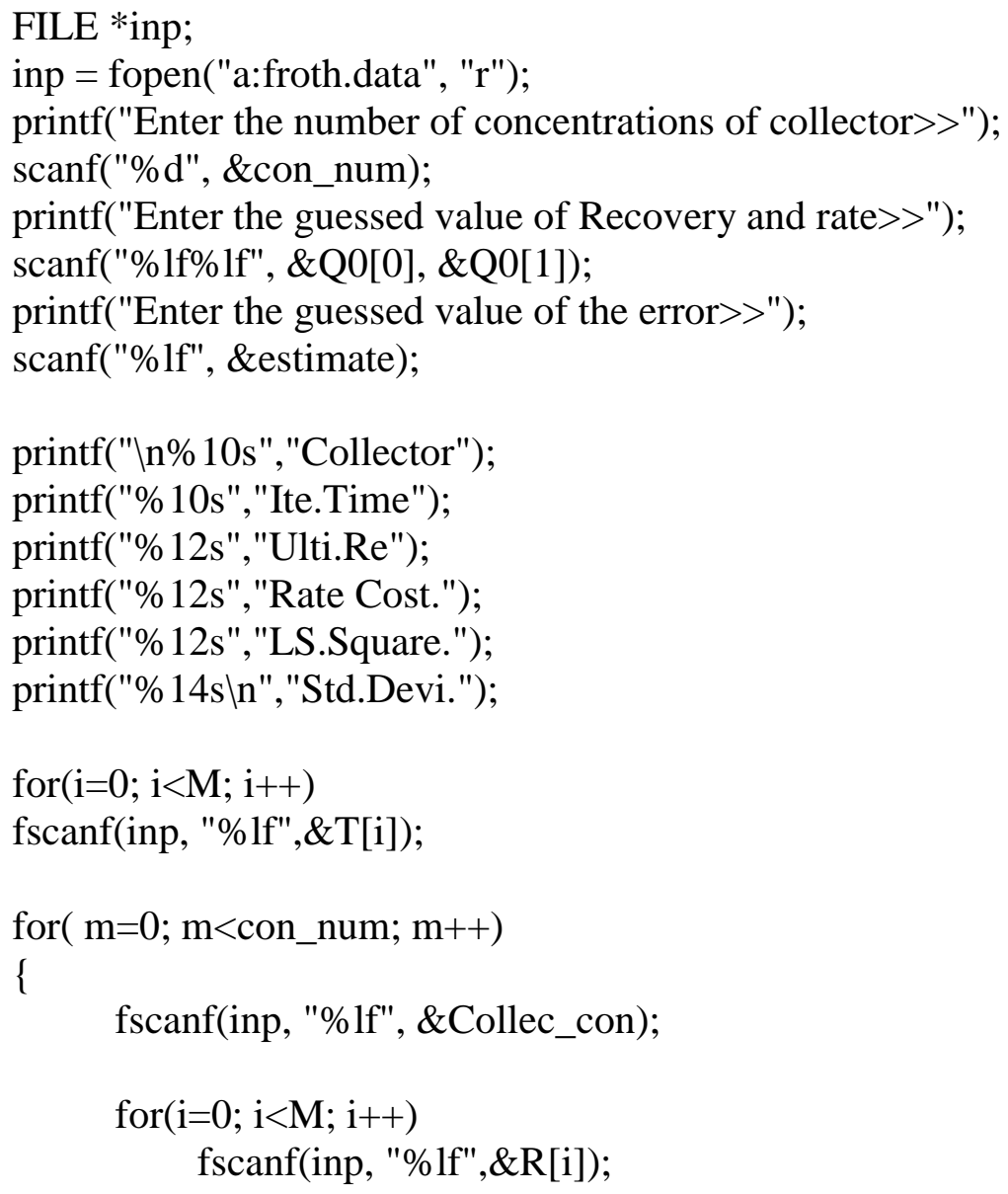

I* call the function of none-linear regression to compute $\mathrm{R}$ ultimate and flotation rate constant*/

none_linear(\&iteration_time,N, Q0,Q, estimate, 
\&sum_square, NUM, ini_step, R, T, FUNCT1 );

/* print out the reults of calculations */

printout(Collec_con, Q, sum_square, iteration_time);

$$
\text { Rate[m] }=\mathrm{Q}[1]
$$

\section{\}}

for $(\mathrm{i}=0 ; \mathrm{i}<\mathrm{N} 2 ; \mathrm{i}++)$

\{

for $(\mathrm{m}=0 ; \mathrm{m}<\mathrm{M} 2 ; \mathrm{m}++)$

\}

fscanf(inp, "\%lf", \&collec[i][m]);

$I^{*}$ call the linear function to compute the relation of collector concentration and rate constant $*$ /

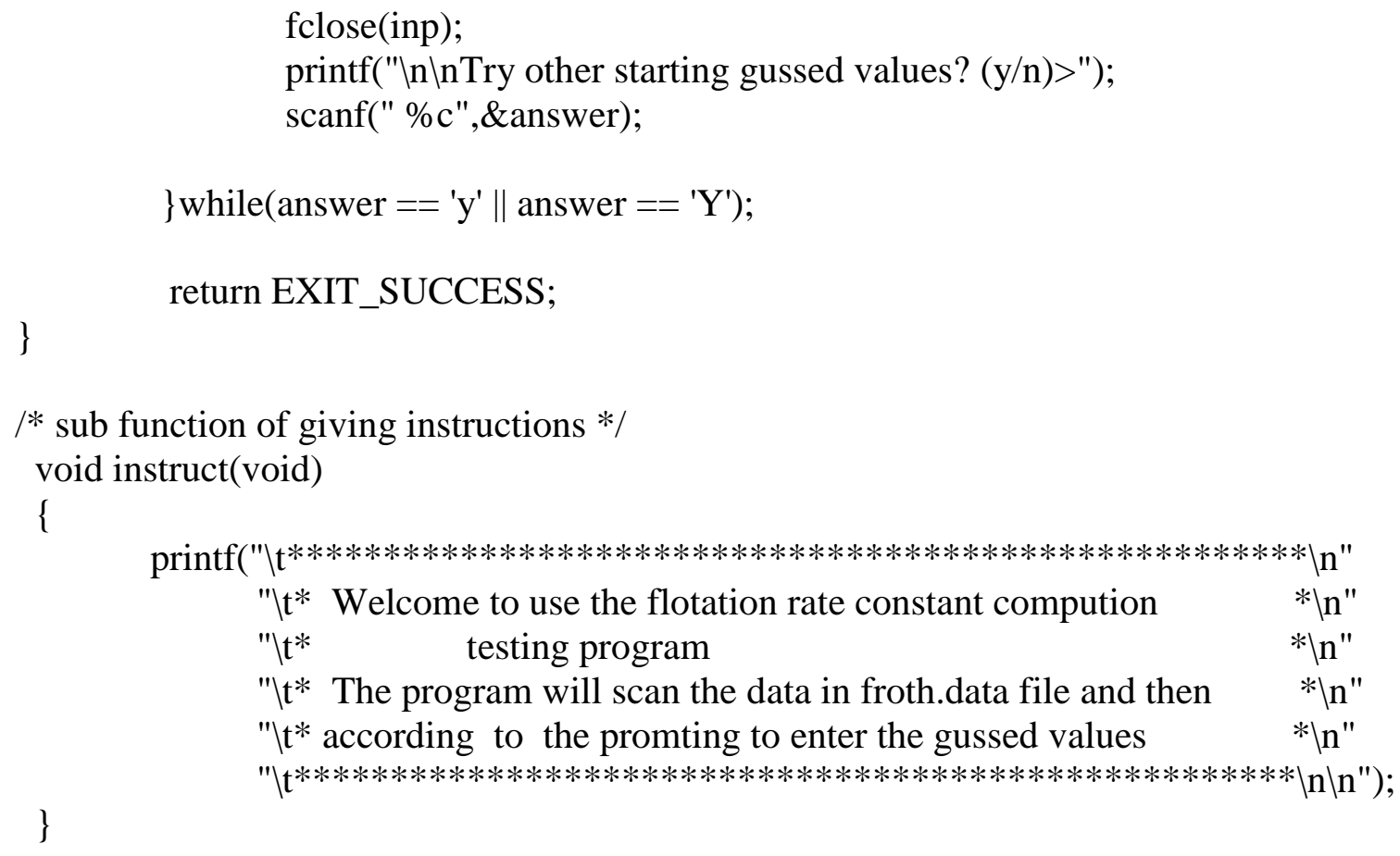
double T3[M], double FUNCT(double X[N], double R3[M], double $\mathrm{T} 3[\mathrm{M}])$ ) 


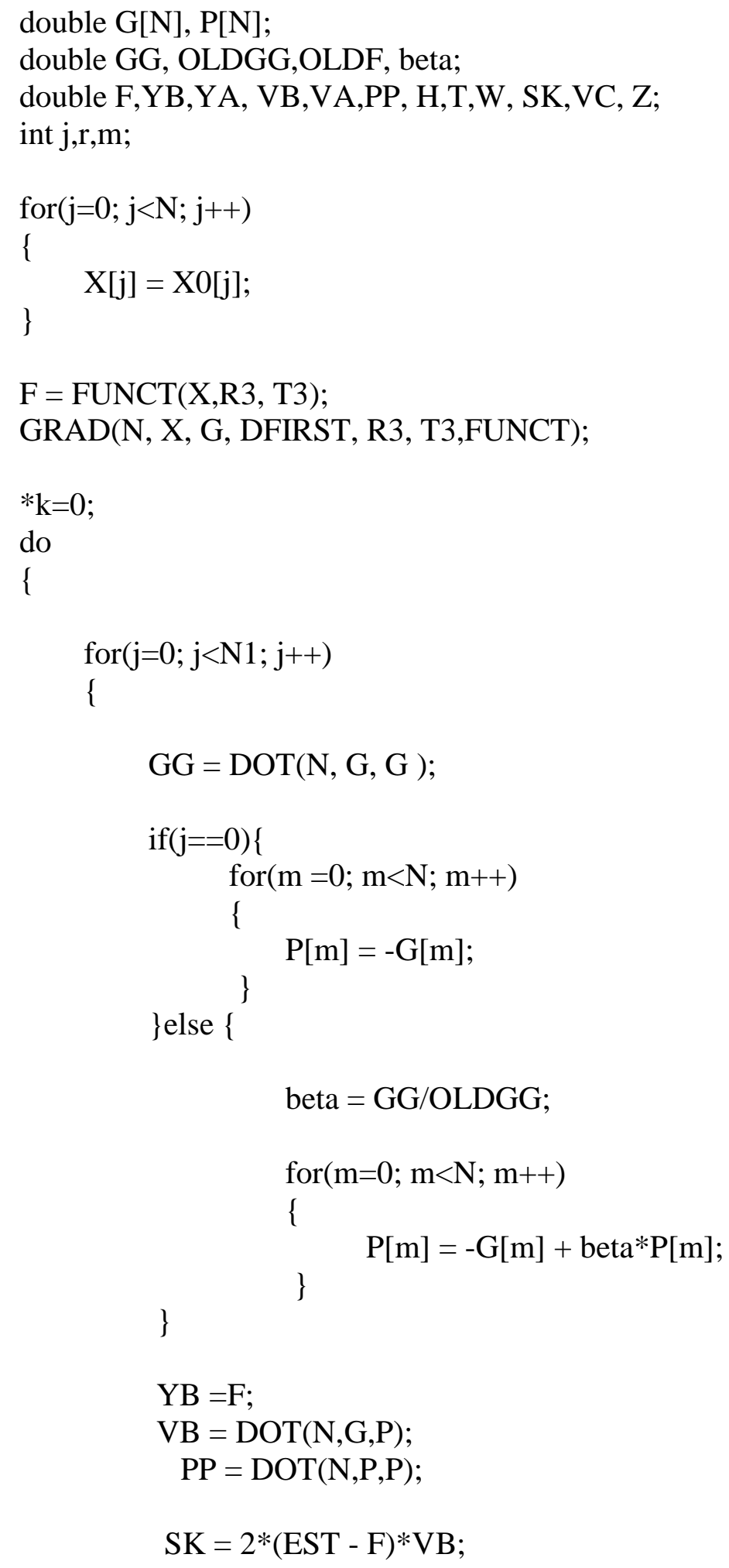




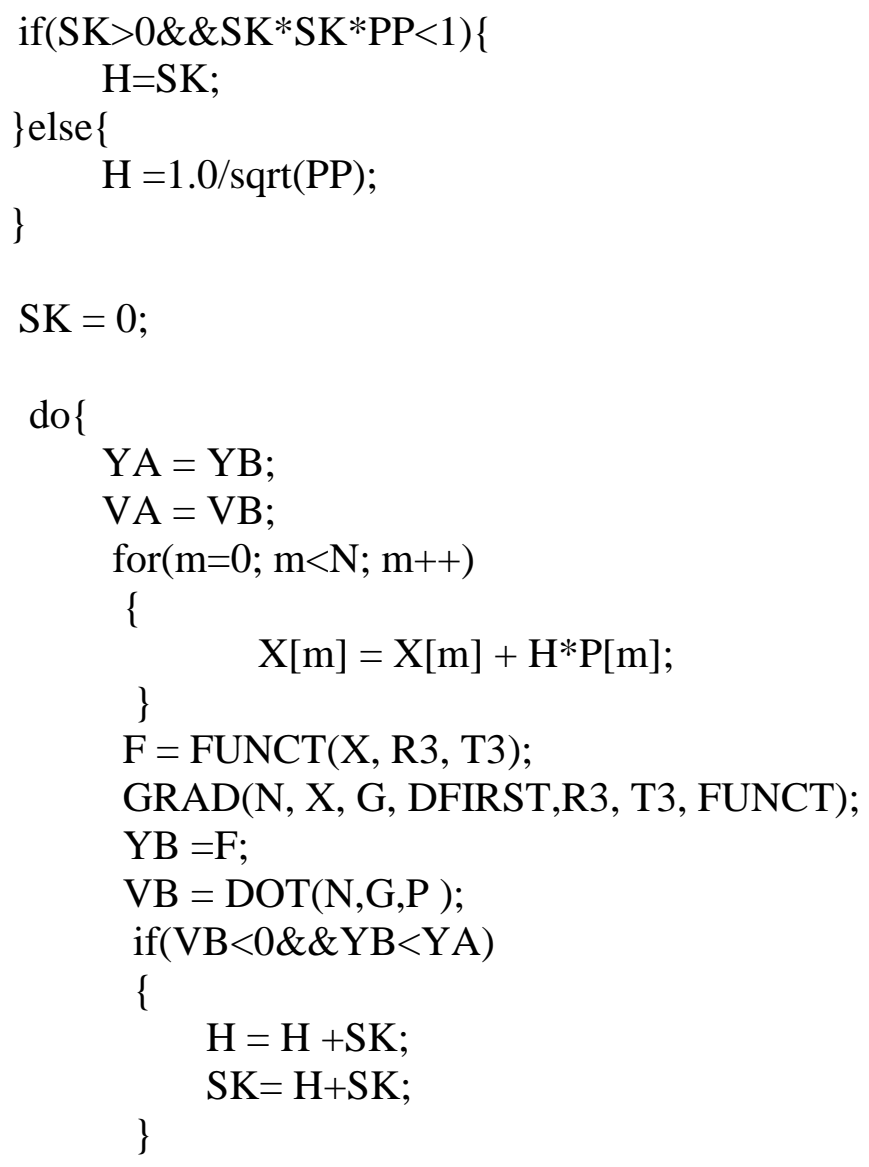




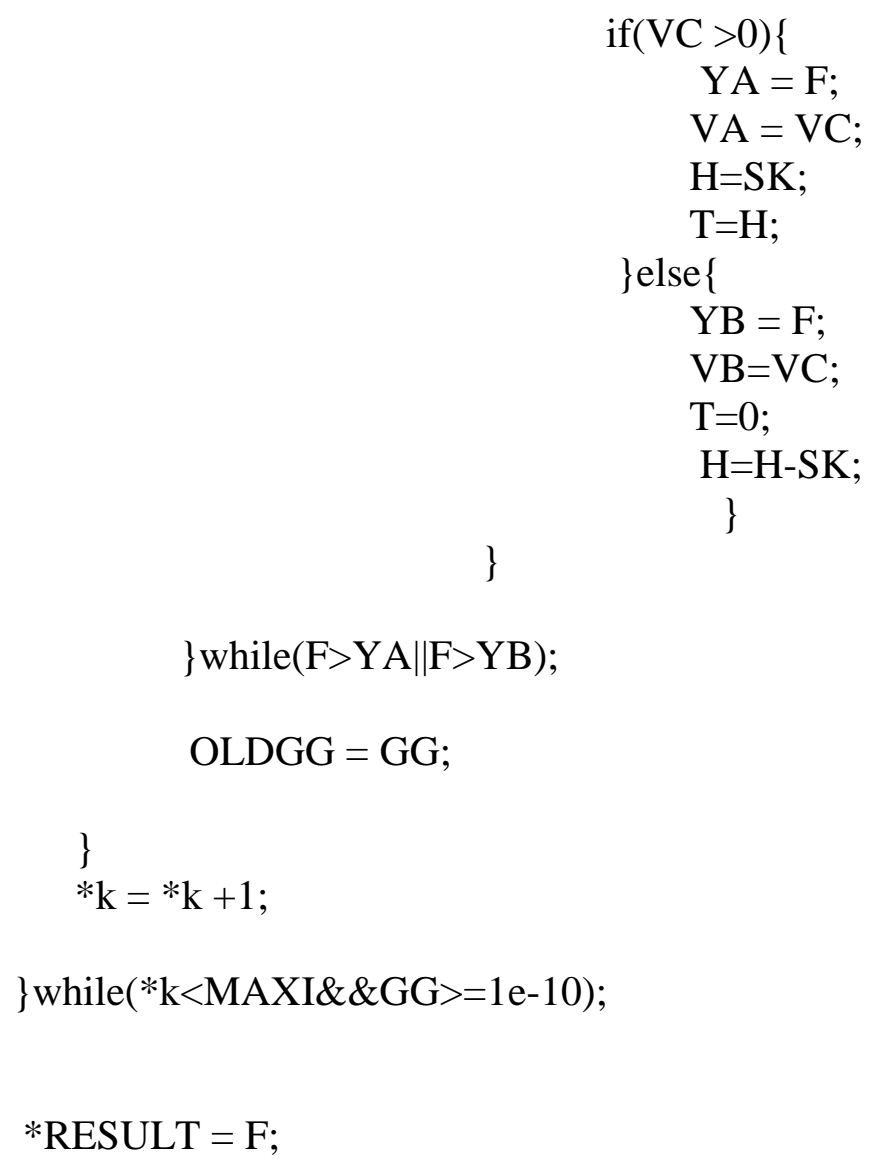




$$
\begin{aligned}
& \mathrm{X} 1[\mathrm{i}]=\mathrm{HZ} \\
& \mathrm{HZ}=0.50 / \mathrm{HF} ; \\
& \mathrm{G} 1[\mathrm{i}]=(\mathrm{FP}-\mathrm{FM}) * \mathrm{HZ} \\
& \quad
\end{aligned}
$$

double FUNCT1( double X1[N], double R1[M], double T1[M])

\{

int $\mathrm{i}$; double $\mathrm{U}=0.0$;

for $(\mathrm{i}=0 ; \mathrm{i}<\mathrm{M} ; \mathrm{i}++)$

\{ $\mathrm{U}+=\operatorname{pow}\left(\left(\mathrm{R} 1[\mathrm{i}]-\mathrm{X} 1[0]^{*}(1.0-(1.0-\exp (-\mathrm{X} 1[1] * \mathrm{~T} 1[\mathrm{i}])) /(\mathrm{X} 1[1] * \mathrm{~T} 1[\mathrm{i}]))\right), 2\right) ;$ \}

$\operatorname{return}(\mathrm{U})$;

\}

/* the sub function for differentiating of euqations */

$/ *$ sub function to calculate the product of two arrays */

double DOT( int $\mathrm{N} 1$, double $\mathrm{A}[\mathrm{N}]$, double $\mathrm{B}[\mathrm{N}]$ )

\{

double T1;

int $\mathrm{i}$;

$\mathrm{T} 1=0$;

for $(\mathrm{i}=0 ; \mathrm{i}<\mathrm{N} 1 ; \mathrm{i}++)$

\{ $\mathrm{T} 1+=\mathrm{A}[\mathrm{i}] * \mathrm{~B}[\mathrm{i}]$

\}

return(T1);

\}

$I^{*}$ sub function of printing out the result $* /$

void printout(double Collec_con, double X[N], double sum_square, int K)

\{

int $\mathrm{i}$;

printf("\n\%4.2f(*50 g/t)", Collec_con);

printf("\%4d", K);

printf("\%15.6f", X[0]);

printf("\%10.6f", X[1]);

printf("\% 14e",sum_square);

\}

printf("\%14eln",sqrt((sum_square/(M-N)))); 
Read the data from data file(a:lfroth.dat):

\begin{tabular}{|c|c|c|c|c|}
\hline 0.33 & 2 & & & \\
\hline 10.4548 & 0.6538 & 0.7199 & 0.7566 & 0.7657 \\
\hline 20.5757 & 0.7070 & 0.7348 & 0.7616 & 0.7701 \\
\hline 30.6350 & 0.7203 & 0.7468 & 0.7616 & 0.7701 \\
\hline
\end{tabular}

\section{Put out the results}

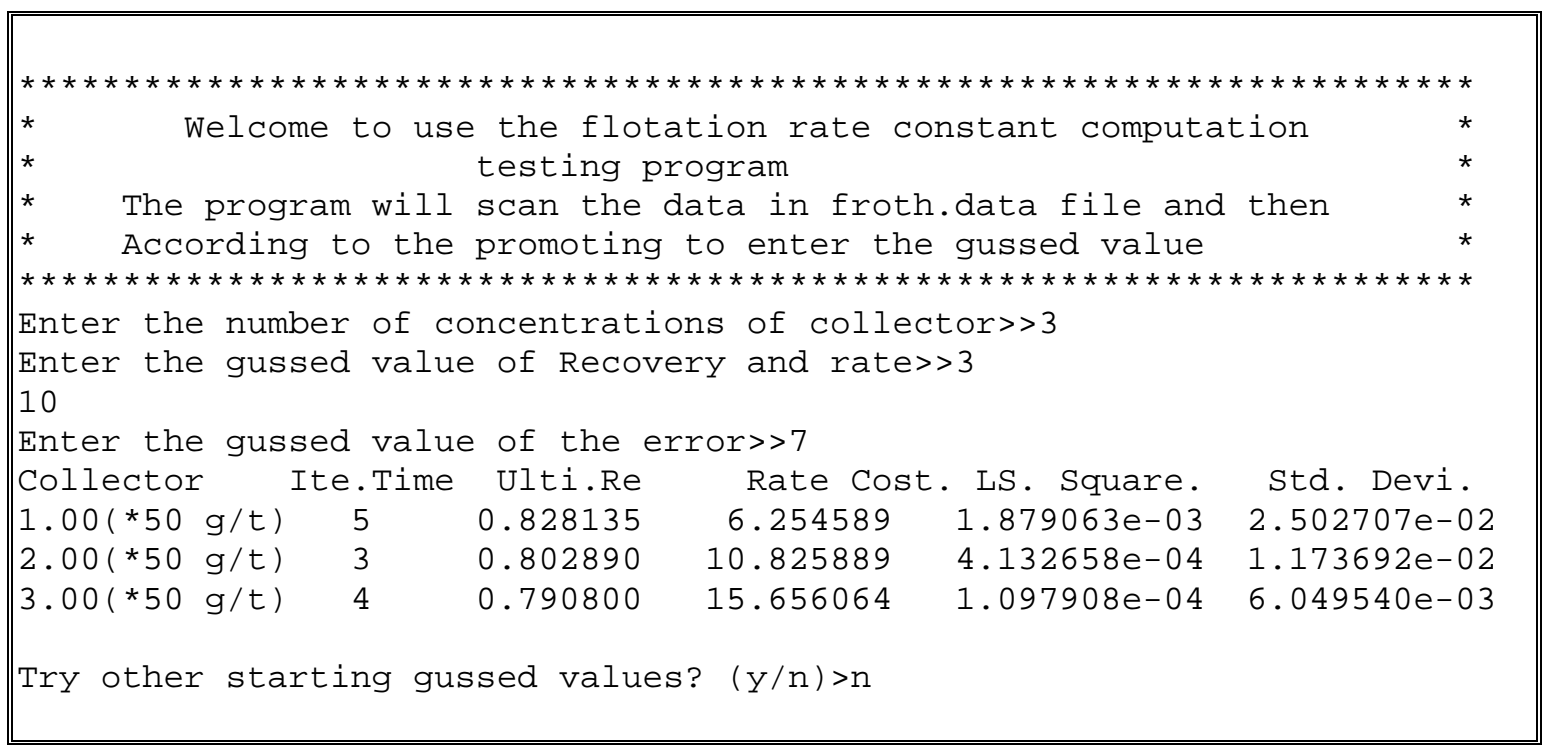




\section{VITA}

Yunkai Xia was born on September 10, 1966 in Haian, Jiangsu, the People's Republic of China. Mr. Xia received his secondary education at Xiachang Middle School and High School from 1980-1984 in Haian, Jangsu. He received his Bachelor of Science Degree in Mineral Engineering from China University of Mining \& Technology (CUMT) in July 1988. In April 1991, he received a Master of Science Degree from Beijing Graduate School from CUMT. In May 1991, Mr. Xia was appointed as a teaching assistant, and later became a lecturer at the Department of Mineral Engineering of CUMT. From July 1993 to December 1995, he was an Engineer involved in the Research and Development of Silicon Carbide Whisker Project in Beijing, China.

From January 1995 to July 1999, Mr. Xia was a project manager in Technology Development Department of American Golden State Group Corp., Beijing Division. On July 1, 1999, Mr. Xia enrolled in the Master of Science program at the Department of Mining Engineering, West Virginia University, Morgantown, West Virginia. Currently he is a candidate of MS degree.

Mr. Xia married with Zimin Ren in 1992, Beijing, China. They have a five-year-old son, Suyu. 